\title{
Geology of Moorhead Coal Field, Powder River, Big Horn, and Rosebud Counties, Montana
}

$\varnothing$ $\begin{array}{llllllllllllllllllllllll}\text { G E O L O G I C A L } & \text { S U R V E Y } & \text { B U L L E T I N } 1338\end{array}$ 


\section{Geology of Moorhead Coal Field, Powder River, Big Horn, and Rosebud Counties, Montana}

By R. P. BRYSON and N. WOOD BASS

GEOL O G I A L S URVEY B UL LET IN 1338

A study of the stratigraphy and areal geology of the Moorhead coal field including a detailed estimate of the reserves of coal 
UNITED STATES DEPARTMENT OF THE INTERIOR

ROGERS C. B. MORTON, Secretary

\section{GEOLOGICAL SURVEY}

V. E. McKelvey, Director 


\section{CONTENTS}

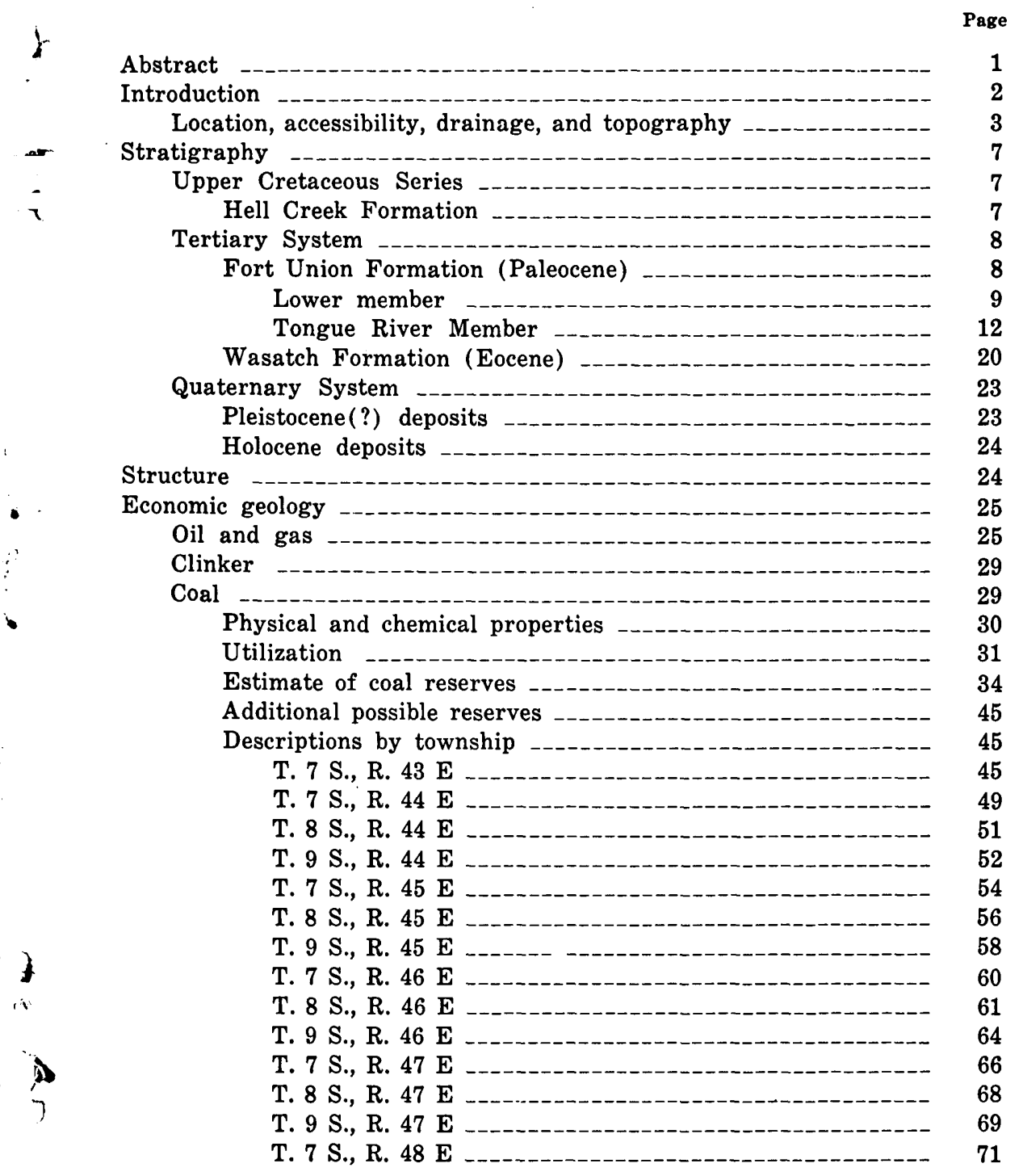


Economic geology-Continued Coal-Continued

Descriptions by township-Continued

T. 8 S., R. 48 E

T. 9 S., R. $48 \mathrm{E}$

T. 7 S., R. 49 E _-_._- 80

T. 8 S., R. 49 E

T. 9 S., R. 49 E _-_

T. 5 S., R. 50 E., partial township _-_ 87

T. 6 S., R. 50 E

T. 7 S., R. $50 \mathrm{E}$

T. 8 S., R. 50 E

T. 9 S., R. 50 E _-_- 94

T. 4 S., R. 51 E., partial township _-_____-__-_ 95

T. 5 S., R. 51 E., partial township -_-_-_-_-_-_ 95

T. 6 S., R. 51 E _- 96

T. 7 S., R. 51 E _- 100

T. 8 S., R. $51 \mathrm{E}$ -

T. 9 S., R. 51 E

T. 4 S., R. 52 E -

T. 5 S., R. 52 E _-_- 107

T. 6 S., R. $52 \mathrm{E}$

T. 7 S., R. $52 \mathrm{E}$

T. 8 S., R. 52 E -

T. 9 S., R. 52 E - 111

References cited -

Index - -

\section{ILLUSTRATIONS}

[Plates are in pocket]

Plate 1. Geologic map of the Moorhead coal field, Big Horn, Rosebud, and Powder River Counties, Montana.

2. Diagram showing stratigraphic position of coal beds.

3-6. Graphic sections, by township, of coal beds in Moorhead coal field:

3. In T. 7 S., R. 43 E.

4. In Tps. 7, 8, 9 S., Rs. 44, 45, 46 E.

5. In Tps. 7, 8, 9 S., Rs. $47,48 \mathrm{E}$.

6. In Tps. $7,8,9$ S., Rs. $49,50,51$ E.

Figure 1. Index map showing location of the Moorhead coal field

2. Map of boundary between subbituminous and lignite coal 
Figures 3-9. Graphic sections, by township, of coal beds in Moorhead coal field:

3. In T. 6 S., R. 50 E -

4. In T. 5 S., R. $51 \mathrm{E}$

5. In T. 6 S., R. $51 \mathrm{E}$

6. In T. 4 S., R. $52 \mathrm{E}$

7. In T. 5 S., R. 52 E -

8. In T. 6 S., R. $52 \mathrm{E}$

9. In Tps. 7, 8, 9 S., R. $52 \mathrm{E}$

\section{TABLES}

TABLE 1. Rocks exposed in Moorhead coal field, Montana

Page

2. Selected analyses of coal from localities in Powder River County, Mont

3. Estimated reserves of coal in Moorhead coal field, Montana, by township

4. Summary by township of estimated reserves of coal in the Moorhead coal field, Montana 


\title{
GEOLOGY OF MOORHEAD COAL FIELD, POWDER RIVER, BIG HORN, AND ROSEBUD COUNTIES, MONTANA
}

\author{
By R. P. Bryson and N. Wood Bass \\ ABSTRACT
}

The Moorhead coal field covers an area of about 1,230 square miles and consists of all or parts of 36 townships in southeastern Montana; it is mostly in Powder River County but includes small parts of Big Horn und Rosebud Counties. The coal field receives its name from the abandoned post office of Moorhead, which is on the west bank of the Powder River in the southcentral part of the mapped area. The Moorhead coal field is only a small part of an extensive coal-bearing region in southeastern Montana and northeastern Wyoming. It is 65 miles southeast of the Northern Pacific Railway and the Chicago, Milwaukee, St. Paul and Pacific Railroad, which follows the Yellowstone River. The Chicago, Burlington \& Quincy Railroad in northern Wyoming passes within 20 miles of the coal field. A paved highway, U.S. Highway 212 , traverses the northeastern part of the field. Roads surfaced with gravel traverse the field, dirt roads and trails reach the remote parts.

Stockraising, mainly of cattle but including some sheep, is the chief industry in the area. Dryfarming is successfully carried on in small parts of the area. The bottom lands along the Powder River are irrigated by water from the Powder River, and to a lesser extent, the bottom lands along the Little Powder River are irrigated by water from that river.

The eastern one-fifth of the mapped area is a broad expanse of rolling grassland which terminates on the west at a relatively steep slope that rises to an extensive partly forested plateau. The plateau is intricately dissected, but large areas within it are treeless gently rolling grasslands.

The Powder River has cut a wide valley northeastward across the east margin of the plateau and thence northeastward across the rolling lowland. Its flood plain ranges in width from $1 / 2$ to 2 miles, and the bed of the river is about 15 feet below the surface of the flood plain. The Little Powder River flows northward across the eastern part of the area, entirely in the rolling lowland of the mapped area, and joins the Powder River about 4 miles south of the north boundary of the area. It, too, has a fairly wide flood plain, and its bed is about 15 feet below the level of the flood plain.

The exposed rocks constitute a sequence about 2,250 feet thick that extends from the uppermost part of the Hell Creek Formation of Late 
Cretaceous age through the lowermost 200 feet of the Wasatch Formation of Eocene age. Most of the sequence is in the Fort Union Formation of Paleocene age, which is divided into two members. The lower member, which is about 400 feet thick, consists of a monotonous sequence of interbedded gray to dark-gray shale, silty shale, dull-brown carbonaceous shale, friable light-gray siltstone, small amounts of light-gray sandstone, and a few thin lenses of coal. The Tongue River Member, which is $1,400-1,600$ feet thick, consists of interbedded light-yellow-gray sandstone, sandy shale, gray shale (some of which is carbonaceous), and coal beds. Most of the coal beds have burned along their outcrops, and the burning has formed layers of baked rock called clinker which appear as thick red ledges in the steep slopes.

The investigation for this report revealed the presence of about 30 beds of coal of mappable thickness and many thin coal beds; some of the beds persist throughout several townships. Only beds 2 feet or more thick were mapped. The total coal reserve, calculated from field data acquired for this report, is $21,579,520,000$ tons; an additional possible reserve of 30 billion tons is estimated to be in coal beds whose maximum depth is less than 2,000 feet.

The mapped area is on the northeastern flank of the Powder River Basin, which is a major structural feature in northeastern Wyoming and southeastern Montana. Although the true attitude of the rocks is evident in the exposed rocks in parts of the mapped area, the regional structure is shown best by a structure contour map based on data from the logs of wells drilled for oil and gas. The rocks dip westward as much as 75 feet per mile where the strike is northward in the eastern third of the mapped area, dip southwestward as the strike changes to northwestward in most of the rest of the area, and dip southward as the strike changes to due west at the western margin of the area.

Chemical analyses of the coal in and near the field show that the coal in the easternmost part is lignite but that in most of the field it is of subbituminous-C rank. No coal mines are now operating in the field, but several truck mines were active in 1940, 1941, and 1946 at the time of the field examination.

The mapped area has been prospected for oil and gas, but commercial quantities of these substances had not been found to 1963. Baked rock, called clinker, is used locally for road metal.

\section{INTRODUCTION}

This report presents the results of a geologic investigation to obtain information about the number, distribution, and thickness of coal beds in an area of about 1,230 square miles in southeastern Montana. In addition, the data include a description of the quality of the coal, the type of roof and floor associated with the coal, and the thickness and character of the overburden. These data aid in the administration of the public coal lands, and the pub- 
lished data are available to anyone who at some future time may desire to exploit the coal.

The field mapping,-under the general supervision of $\mathrm{H}$. D. Miser, was done during the summers of 1940, 1941, and 1946 by R. P. Bryson, party chief, assisted by W. H. Hass, M. W. Ellis, R. B. Neumann, W. W. Olive, and F. S. MacNeil. The townships mapped by these geologists are shown on an index map on the geologic map (pl. 1).

The cordial treatment and many courtesies to all members of the field party by the ranchers throughout the area and by the townspeople of Broadus are gratefully acknowledged.

The coal field was mapped in the field on aerial photographs. The position of formation and member boundaries, coal beds, clinker, coal mines, localities where sections of the coal beds were measured, streams, ranch buildings, and wells was placed on the photographs. In addition, many section corners-those identified on the ground-were plotted on the photographs to improve the accuracy of the land net shown on the geologic map. A few long key stratigraphic sections, involving sequences of rocks many hundreds of feet thick, and many short stratigraphic sections, each involving sequences as much as 300 feet thick, were measured by hand leveling. Stratigraphic intervals between coal beds were determined by hand leveling. Detailed sections of the coal beds were measured by steel tapes. The coal beds were exposed by digging with pick and shovel at many localities, and the rocks directly below and those directly above the coal bed were recorded for most coal sections.

The geologic map and other illustrations were compiled by or under the supervision of R. P. Bryson. The estimate of coal reserves were made in part by Donald M. Brown, H. R. Christner, and Catherine Bowen Jordan. The final report, however, was prepared in 1963 by N. Wood Bass after Mr. Bryson left the U.S. Geological Survey.

\section{LOCATION, ACCESSIBILITY, DRAINAGE, AND TOPOGRAPHY}

The Moorhead coal field receives its name from the abandoned post office of Moorhead, which is on the west bank of the Powder River in the south-central part of the mapped area. It consists of all or part of 36 townships-about 1,230 square miles-in southeastern Montana, chiefly in Powder River County but including small parts of Big Horn and Rosebud Counties. The coal field is 


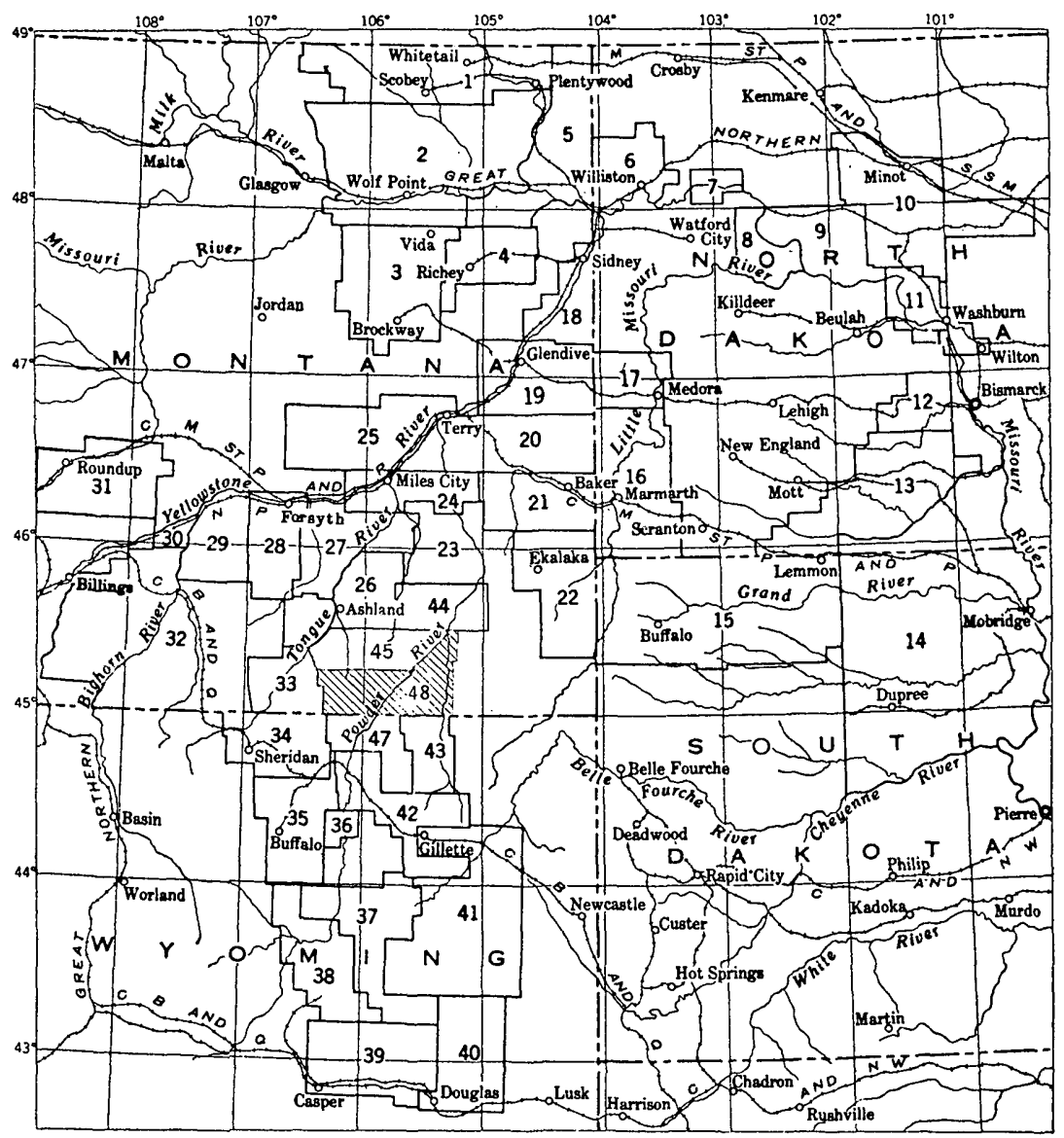

0

100 MILES

FigURe 1.-Index map showing location of the Moorhead coal field (hachured) and other coal fields in southeastern Montana and adjacent States.

a small part of the extensive coal-bearing Powder River region in southeastern Montana and northeastern Wyoming. The location of the field relative to other coal fields in southeastern Montana, northeastern Wyoming, northwestern South Dakota, and southwestern North Dakota is shown on the index map (fig. 1).

The Northern Pacific Railway and the Chicago, Milwaukee, St. Paul and Pacific Railroad, which follow the Yellowstone River, are 65 miles northwest of the field, and the Chicago, Burlington \& Quincy Railroad is 20 miles south of it in Wyoming. U.S. High- 
Coal fields shown in figure 1 and described in Geological Survey bulletins Index No. and coal field or area

Bull.

1. Scobey
2. Fort Peck
4. Richey-Lambert
5. Culbertson
6. Williston
7. Nesson Anticline
8. Fort Berthold
9. Fort Berthold

751-E

381-A

905

847-C

471-D

531-E

691-G

726-D

10. Minot

$471-\mathrm{C}$

11. Washburn _... 381-A

12. New Salem _........ 726-A

13. Cannonball River _.... 541-G

14. Standing Rock and Cheyenne

Reservations _...

15. Northwestern South Dakota _._____ 627

16. Marmarth _... 775

17. Sentinel Butte _._. 341-A

18. Sidney _... 471-D

19. Glendive _._. 471-D

20. Terry _......... 471-D

21. Baker _... 471-D

22. Ekalaka _... 751-F

23. Mizpah -...- 906-C

24. Miles City . ..... . ............ 341-A

25. Little Sheep Mountain . . ........ 531-F

26. Ashland ...................... 831-B

27. Rosebud ....................... 847-B

28. Forsyth ....... 812-A

29. Tullock Creek ................. 749

30. Southwest of Custer _........... $541-\mathrm{H}$

31. Bull Mountain ... ............... 647

32. Big Horn County ... . . .......... 856

33. Northward extension of Sheridan coal field ... 806-B

34. Sheridan _......... 341-B

35. Buffalo _..... 381-B

36. Barber ............ 531-I

37. Pumpkin Buttes .................. 806-A

38. Sussex .......... 471-F

39. Glenrock ......... 341-B

40. Lost Spring _...... 471-F

41. Gillette _.................... 796-A

42. Powder River ...................... 381-B

43. Little Powder River . . . _..... 471-A

44. Coalwood _........ 973-B

45. Birney-Broadus field _..._._____ 1072-J

47. Spotted Horse _................. 1050

48. Moorhead (this report)

1 With a chapter on the Minturn district and the northwestern part of the Gillette field by W. T. Thom, Jr. 
way 212, a paved road, traverses the northeastern part of the coal field. Graveled roads extend along the Little Powder River valley, part way along the Powder River valley, and along Bloom Creek in the eastern part and along Otter, Hanging Woman, and Lee Creeks in the western part of the field. All parts of the coal field are traversed by dirt roads and trails.

The eastern part of the coal field is drained by the Powder and Litle Powder Rivers and their tributaries, and the western part is drained by Hanging Woman and Otter Creeks, which are tributaries of the Tongue River. The Powder River flows northeastward on an alluvial flood plain that is 1/2-2 miles wide. Much of the flood plain is irrigated farm land on which alfalfa, corn, barley, and other crops are grown. The Little River flows northward near the east margin of the map area to its confluence with the Powder River about 4 miles south of the north boundary of the map area. The Little Powder River meanders on a partly cultivated flood plain that is generally $1 / 2-1$ mile wide. Groves of cottonwood trees are common along the stream. The western part of the area is drained northwestward by intermittent tributary streams of Otter and Hanging Woman Creeks.

The most striking physiographic features of the area are the broad rolling expanses of grassland in the eastern one-fifth and the extensive plateau that occupies the remaining four-fifths of the area. The two features are separated by an abrupt east slope (locally an escarpment) that passes northwestward about 4 miles northwest of Broadus and that can readily be seen from U.S. Highway 212. The rolling grassland in the eastern part is underlain by the lower member of the Fort Union Formation, which consists chiefly of a thick nonresistant sequence of interbedded shale and slightly consolidated siltstone. The pleateau on the west is underlain by the Tongue River Member of the Fort Uniona more resistant sequence of interbedded thick massive sandstone, shale, thick coal beds, and thick clinker, which is formed by the natural burning of the coal.

Although the eastern lowland is generally treeless rolling grassland, isolated buttes that have partly barren banded slopes of drab gray shale and siltstone rise above the general surface. Tributaries of the Little Powder River flow intermittently in steep-sided gulches that are characterized by barren outcrops of drab shale and siltstone. The upper courses of these tributaries 
have broad gently sloping valleys that blend with, and are a part of, the rolling grassland.

The main plateau has a gently rolling grass-covered surface; its margins, which consist of thick clinker, are intricately dissected by gulches occupied by intermittent streams. Pine trees grow on the clinker and along a belt several hundred feet wide behind the clinker boundaries. The plateau surface is really a series of broad benches, each succeeding higher bench being floored by a stratigraphically higher coal bed or clinker and its associated sandstone beds. The highest benches in any given part of the plateau form the flat-topped narrow divides between the major streams. On both sides of the Powder River, the plateau has barren steep-sided gulches and narrow divides whose local relief is as much as 400 feet. The upper tributaries of Otter and Hanging Woman Creeks occupy relatively broad and shallow valleys. The valleys of Baking Powder, Butte, Buttermilk, Bay Horse, and Three Bar Creeks are shallow and as much as a mile wide and have gentle slopes that terminate in ledges of clinker on the margins of rugged interstream areas. Parts of the plateau surface are dry-farmed; most of it is grazing land, used largely for cattle.

\section{STRATIGRAPHY \\ UPPER GRETACEOUS SERIES \\ HELL CREEK FORMATION}

An undetermined thickness, probably 50-75 feet, of the upper part of the Hell Creek Formation is poorly exposed in the valleys of Ranch and Wright Creeks on the southeast margin of the coal field (see table 1 ). Because these valleys are largely grass-covered slopes and very little bedrock is exposed, the formation boundary as shown on the geologic map is approximately located. The upper part of the Hell Creek Formation in the adjacent area to the north, and presumably also in the mapped areas, consists of interbedded gray shale, silty shale, and very fine grained gray silty sandstone and siltstone (Bryson, 1952, p. 39-43). The formation closely resembles the overlying lower member of the Fort Union Formation, and the boundary between the two in the Coalwood coal field to the north was drawn arbitrarily at the base of the lowest bed of lignite. It was not possible to establish and map a uniform stratigraphic horizon "because the lowest lignite bed is very thin in some parts of the field and there may be no coal at 
TABLE 1-Rocks exposed in Moorhead coal field, Montana

\begin{tabular}{|c|c|c|c|c|c|}
\hline System & Series & \multicolumn{2}{|c|}{$\begin{array}{l}\text { Formation } \\
\text { and } \\
\text { member }\end{array}$} & $\begin{array}{c}\text { Thickness } \\
\text { (feet) }\end{array}$ & Description and correlation \\
\hline \multirow[b]{2}{*}{ Quaternary } & Holocene & \multicolumn{2}{|r|}{ Alluvium } & $5-25$ & $\begin{array}{l}\text { Silt, sand, and local lenses of gravel. Wide } \\
\text { belts of alluvium along the Powder } \\
\text { and Little Powder Rivers and narrow } \\
\text { belts along all major tributaries. }\end{array}$ \\
\hline & Pleistocene(?) & \multicolumn{2}{|c|}{$\begin{array}{l}\text { Terrace } \\
\text { deposits }\end{array}$} & $5-65$ & $\begin{array}{l}\text { Mostly poorly sorted flat pebbles, having } \\
\text { rounded edges, of clinker and sand- } \\
\text { stone derived locally; many of the } \\
\text { higher gravel deposits contain meta- } \\
\text { morphic and igneous rock. A few } \\
\text { terraces contain some boulders more } \\
\text { than } 1 \text { foot in diameter. }\end{array}$ \\
\hline \multirow{3}{*}{ Tertiary } & Eocene & \multicolumn{2}{|c|}{$\begin{array}{l}\text { Wasatch } \\
\text { Formation }\end{array}$} & 200 & $\begin{array}{l}\text { Shale, somber gray-brown and gray: } \\
\text { some carbonaceous shale; some brown } \\
\text { sandstone in thin beds; several beds } \\
\text { are principally coquinas of clams and } \\
\text { snails. Most of formation is composed } \\
\text { of relatively soft rocks which erode } \\
\text { readily into gentle treeless slopes on } \\
\text { which beds of sandstone form small } \\
\text { ledges. }\end{array}$ \\
\hline & \multirow{2}{*}{ Paleocene } & \multirow{2}{*}{ 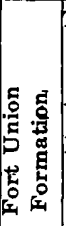 } & $\begin{array}{l}\text { Tongue } \\
\text { River } \\
\text { Member }\end{array}$ & $1,400-1,600$ & $\begin{array}{l}\text { Interbedded thick beds of light-yellow- } \\
\text { gray sandstone, sandy shale, and gray } \\
\text { shale, some of which is carbonaceolis; } \\
\text { about } 30 \text { thick beds of coal. }\end{array}$ \\
\hline & & & $\begin{array}{l}\text { Lower } \\
\text { member }\end{array}$ & 400 & $\begin{array}{l}\text { Interbedded gray to dark-gray shale, } \\
\text { silty shale, dull-brown carbonaceous } \\
\text { shale, small lenses of light-gray sand- } \\
\text { stone, and a few thin lenticular beds } \\
\text { of coal. }\end{array}$ \\
\hline Cretaceous & $\begin{array}{l}\text { Upper } \\
\text { Cretaceous }\end{array}$ & & $\begin{array}{l}\text { ell Creek } \\
\text { Formation }\end{array}$ & $50-75$ & $\begin{array}{l}\text { Interbedded gray shale, silty shale, very } \\
\text { fine grained gray silty sandstone, and } \\
\text { siltstone. }\end{array}$ \\
\hline
\end{tabular}

this horizon in other parts," according to Bryson (1952, p. 43). In general, the uppermost part of the Hell Creek contains thick buff to greenish-gray very fine grained friable sandstone. Dinosaur bones are present in the Hell Creek Formation, but they are absent from the overlying beds.

\section{TERTIARY SYSTEM}

\section{FORT UNION FORMATION (PALEOCENE)}

The entire Fort Union Formation, about 2,000 feet thick, is present in the mapped area. It is divisible into two members: the lower member, about 400 feet thick, and the overlying Tongue River Member, 1,400-1,600 feet thick. The formation consists of interbedded sandstone, siltstone, shale, and coal. The lower member consists predominantly of shale, friable siltstone and sandstone, and a few thin lenticular beds of coal. The Tongue River 
Member consists of interbedded massive beds of sandstone, shale, and thick coal beds. Thick clinker commonly is present where coal beds have burned along the outcrop.

\section{LOWER MEMBER}

The lower member of the Fort Union Formation consists of a monotonous sequence of interbedded gray to dark-gray shale and silty shale, many beds of locally coaly dull-brown carbonaceous shale, light-gray siltstone, and very fine grained light-gray sandstone. The sandstone weathers yellow gray or dark-rust brown. In addition, the member contains a few thin lenticular beds of coal more than 2 feet thick and many lenticular beds of coal that range in thickness from 2 inches to 18 inches but which commonly are 6-10 inches thick. Parts of the lower member, totaling as much as a few hundred feet in thickness, form banded bare cliffs and steep slopes which present a somber badlands aspect; mediumdark grays, some tinted with brown, predominate, enlivened only by a few bands of light-gray or yellow-gray beds of siltstone and sandstone. The dark-brown sandstone is cemented with iron oxide and commonly caps buttes and narrow ridges. This sandstone is crossbedded in a very irregular and wavy manner, and loglike concretions are common. The concretions persist for hundreds of feet and many occur in parallel arrangement; their appearance suggests that they were formed as giant ripples. Some beds of sandstone and siltstone are calcareous; others are noncalcareous. Many beds of siltstone are very friable and are virtually unconsolidated.

The member seems to become more sandy。 southward. It contains less sandstone in the barren buttes west of the Powder River and 1-2 miles northeast of Broadus than it does where exposed in the southeastern part of T. 8 S., R. 52 E., and the eastern part of T. 9 S., R. 52 E.

The lower member forms a generally treeless lowland east of the partly forested plateau formed by the Tongue River Member. This lowland ranges from gently rolling grass-covered terrain in its western part to steeply rolling country near the Powder and Little Powder Rivers. Isolated barren buttes and ridges rise above the general surface on interstream divides, particularly near the two main rivers; patches of exposed beds characterize the steeper slopes, particularly those facing southwest. Possibly 10 percent of the land is dry-farmed. 
The valley of the Little Powder River, which is cut into the lower member, has a wide meandering flood plain that extends northward across most of the lowland belt of country to the river's confluence with the Powder River, only 4 miles south of the northern boundary of the mapped area. Groves of cottonwood trees grow along and near the river channel.

The following is a detailed stratigraphic section of the lower member measured in the southeastern part of T. 8 S., R. 51 E., and the southwestern part of T. 8 S., R. 52 E.:

Section of the lower member of the Fort Union Formation in sec. 24, T. 8 S., R. 51 E., and secs. 30 and 33, T. 8 S., R. 52 E., Montana

[Measured by W. H. Hass]

Tongue River Member of Fort Union Formation:

Contact coal bed

Feet

ower member of Fort Union Formation:

Shale, chocolate-brown; in part greenish yellow

Shàle, gray-white to light-yellow-brown; in part sandy; some siltstone in basal $3 \mathrm{ft}$

Clay shale; several somber shades of grayish brown and chocolate brown; contains gypsum crystals

Sandstone, light-gray-brown to gray-white; contains streaks of purple brown and rusty brown; fine grained, calcareous, crossbedded; friable to ledge forming

Covered, mostly; top $30 \mathrm{ft}$ has much dark-brown to black sandy shale and some coaly shale

Sandstone; grayish white on fresh exposure, weathers light yellow brown and rusty brown; fine to medium grained, calcareous, crossbedded; massive and ledge forming; weathers into blocks and slabs $2 \times 6 \times 6 \mathrm{ft}$

Covered; outcrops nearby suggest 90 percent sandstone; gray white to light gray brown, fine to medium grained, calcareous; friable to cliff forming

Sandstone, light-yellow-brown, calcareous, crossbedded; friable and has some indurated layers; contains marcasite nodules half an inch in diameter

Shale, brown to black; contains coal stringers, rest light gray brown; top half foot carbonaceous

Sandstone, gray-brown to light-yellow-brown, slightly calcareous, friable; contains marcasite nodules half an inch in diameter

Shale, gray-brown to yellow-brown, sandy, calcareous

Siltstone, light-gray-brown to light-yellow-brown, calcareous; weathered surfaces are hackly

Sandstone, light-yellow-brown to light-gray-brown, calcareous, friable; has some indurated layers 
Section of the lower member of the Fort Union Formation in sec. 24, T. 8 S., R. 51 E., and secs. 30 and 33, T. 8 S., R. 52 E., Montana-Continued

Lower member of Fort Union Formation-Continued

Shale, light-gray-brown to light-yellow-brown; some layers of siltstone less than a tenth of a foot thick; some crystals of gypsum as much as $3 \mathrm{in.} \mathrm{long}$

Shale, light-yellow-brown to rusty-brown, sandy; contains irregularly shaped concretions

Sandstone, light-gray-brown to light-yellow-brown, slightly calcareous, friable; some carbonaceous plant remains; some marcasite nodules half an inch in diameter

Siltstone, light-yellow-brown; weathers rusty brown, calcareous; weathers hackly to thin plates

Shale; several shades of light gray brown and light yellow brown, laminated; weathers hackly

Shale, chocolate-brown

Coal, granular

Shale, light-gray-brown, hackly

Sandstone (partly concealed), grayish-white to light-graybrown to rusty-brown, calcareous, crossbedded; in part friable, in part indurated into ledge-forming beds $2 \frac{1}{2} \mathrm{ft}$ thick; top $3 \mathrm{ft}$ leaf bearing, ledge forming

Concealed; partly exposed light-yellow-brown friable sandstone --

Siltstone, blue-gray; weathers light yellow brown to rusty brown, calcareous; hackly surface

Shale, partly concealed, gray-brown to yellow-brown; weathers hackly

Concealed; exposures elsewhere suggest at least lower $30 \mathrm{ft}$ is sandstone

Sandstone, grayish-white, calcareous, friable

Siltstone, light-gray-brown to rust-brown, calcareous; weathers hackly

Sandstone, grayish-white to light-gray-brown, calcareous, friable; contains marcasite nodules as much as $1 \frac{1 / 2}{\mathrm{in}}$. across

Concealed; probably grayish-brown shale

Sandstone, light-gray-brown to gray-white, fine-grained, calcareous, friable; in part indurated into ledge-forming beds $2 \mathrm{ft}$ thick

Sandstone, light-gray-brown, medium- to fine-grained, calcareous, crossbedded, indurated, ledge-forming

Sandstone, light-gray-brown to grayish-white, fine-grained, calcareous, friable; contains leaves

Shale, light- to dark-gray-brown; weathers hackly

Shale, chocolate-brown to black and sooty

Coal, sooty; has chocolate-brown shale at base

Concealed

Total lower member of Fort Union Formation 
TONGUE RIVER MEMBER

The Tongue River Member consists of interbedded light-yellowgray sandstone, sandy shale, gray shale (some of which is carbonaceous), and coal. The thickness of the member ranges from 1,400 to 1,600 feet. Ledges of red clinker are conspicuous. Many of the sandstone units are either massive or crossbedded, are from 50 feet to more than 100 feet thick, and form prominent ledges in steep slopes and pinnacles on gentle slopes. Thick sandstone units are present at short distances below the principal coal beds and, as was noted in the Ashland coal field (Bass, 1932, p. 35), they commonly crop out in cliffs below ledges of clinker.

Many coal beds are present in the member, and many persist over several townships. Along stream banks and other local areas, fresh unburned coal was mapped; in most parts of the area, however, the coal has been burned and clinker was mapped. In many places it is not known whether a clinker represents a single coal bed or two or more closely associated beds. It is possible, therefore, that a coal bed delineated on the map really may be a coal zone.

The coal beds in the Tongue river Member are thicker and more persistent than the coal beds in the lower member. Many are more than 10 feet thick throughout many square miles, and some are more than 20 feet thick.

A sequence that is repeated many times in the Tongue River Member consists of an upward succession of massive faintly crossbedded sandstone about 40-100 feet thick, shale and clay only a few feet thick, and a thick coal bed overlain by rocks of widely varying thickness in which shale predominates. No doubt this sequence of rocks represents the deposits of an environment that was repeated many times. It has been pointed out by Brown (1952) and by Thom and Dobbin (1924, p. 485) that these rocks were deposited in a flood-plain environment that persisted throughout an extensive region. The many coal beds indicate repeated marsh and swamp conditions, and the interfingering with marine beds in North Dakota (Brown, 1952, p. 92) shows

*** that the coal-forming swamps, pools, or lakes were practically at sea level but at varying distances inland from the sea. This means that the basin receiving the Fort Union sediments was unstable, standing still for a time while vegetable material accumulated, then subsiding and permitting the incipient lignite to be buried beneath muds or sands; and so on until several thousand feet of strata with coal seams were laid down, the land source of the sediments to the west meanwhile undergoing the spasmodic orogenic uplifts of the continuing Laramide Revolution and the sea to the 
east maintaining its position until probably well into Eocene time, when it retreated from the interior of the continent.

The thick sandstone beds and the principal coal beds were probably deposited in littoral and coastal swamp environments, respectively. During periods of eastern regression of the sea, each environment of deposition moved eastward, maintaining its approximate position relative to the coast line. The coastal swamp deposits thus prograded eastward across the underlying littoral sandstone deposits. The thick interbedded light- and dark-gray shale that commonly overlies the coal beds represents either a period of subsidence that moved the shore far westward or an accelerated deposition of sediment that was derived from a low-lying landmass.

The lower boundary of the Tongue River Member is the base of the sequence characterized by a predominance of light-yellowgray sandstone. Inasmuch as similar sandstone is present locally in the lower member, a coal bed herein called the Olsen or Contact (13) bed was arbitrarily chosen to represent the basal bed of the Tongue River Member; where the coal is absent, a thick zone of dark-gray carbonaceous shale is present, and the member boundary is drawn at the base of the shale. The upper boundary of the member is drawn at the top of the Roland coal bed, which persists in the western part of the coal field and into adjacent coal fields. At most places the Roland coal bed is overlain, at various intervals above it, by at least one thin coquina composed of freshwater clams and snails.

The following is a detailed stratigraphic section of the Tongue River Member of the Fort Union Formation:

\section{Composite stratigraphic section of the Tongue River Member of the Fort Union Formation}

[Units 23-156 measured by W. H. Hass; units 1-22 measured by M. W. Ellis]

Wasatch Formation.

Fort Union Formation:

Tongue River Member (sec. 11 and 12, T. 9 S., R. 45 E.) :

156. Roland coal and ash

155. Shale, light-gray to light-brown, sandy

154. Soot (coal bed)

153. Shale, light- to dark-chocolate-brown, sandy

152. Sandstone, light-brown, fine-grained, friable; contains a few thin layers of rusty-brown siltstone. Lower $5 \mathrm{ft}$ contains fossil clam and snails 
Composite stratigraphic section of the Tongue River Member of the Fort Union Formation-Continued

Fort Union Formation-Continued

Ft in.

Tongue River Member-Continued

151. Sandstone, light-brown, medium- to coarsegrained, calcareous, crossbedded; forms ledges -

150. Sandstone, gray-white, fine-grained, crossbedded, friable

149. Sandstone, light-brown, medium- to coarsegrained, calcareous, crossbedded; form ledges; contains many fossil clams and snails

148. Sandstone, light-gray, crossbedded, friable; contains plant remains

147. Shale, light-gray to yellow-brown, sandy

146. Shale, coaly, chocolate-brown and some lightbrown; interbedded with light-gray-brown sandstone layers in basal half foot; contains silicified wood

145. Sandstone, gray-white; has streaks of light yellow brown and dark brown; coarse grained, calcareous, crossbedded, friable; contains thin lenses of siltstone in basal $3 \mathrm{ft}$

144. Shale; in part coaly, chocolate brown to black, slightly sandy; contains many plant remains

143. Shale; somber shades of gray and brown; contains a few layers less than 2 in. thick of rustybrown siltstone

142. Sandstone, chocolate-brown to gray-brown, shaly; contains many plant remains

141. Coal; contains many silicified stumps

Tongue River Member (offset to sec. 11, T. 7 S., R. 47 E., thence down Bloom Creek to SE 1/4 sec. 7, T. 7 S., R. 48 E. Hass calls this the Diamond Butte bed.) :

140. Partly covered; some chocolate-brown shale $3 \quad 10$

139. Mostly covered; some gray-white friable sandstone

138. Siltstone; blue gray when fresh, rusty brown when weathered, calcareous

137. Covered; some gray-white and light-yellowbrown, friable sandstone

136. Siltstone; blue gray when fresh, rusty brown when weathered, calcareous

135. Covered; a few exposures of light-yellow-brown and gray shale, gray-white sandstone, and lightbrown siltstone

134. Siltstone; blue gray when fresh, light yellow brown when weathered, calcareous

133. Covered; some light-yellow-brown shale 
Composite stratigraphic section of the Tongue River Member of the Fort Union Formation-Continued

Fort Union Formation-Continued

Tongue River Member-Continued

132. Coal, sooty; contains silicified wood (may be the Smith bed)

131. Covered; some chocolate-brown and light-yellowbrown shale; a few beds of brown siltstone less than $1 \mathrm{ft}$ thick

130. Sandstone, light-yellow-brown, medium-grained, calcareous; forms ledges _...... 30

129. Covered; some light-brown shale

128. Shale, chocolate-brown

127. Coal _-

126. Shale, chocolate-brown _._._. 10

125. Shale, gray-white to light-yellow-brown _-_._- 40

124. Siltstone; blue gray when fresh, yellow to rusty brown when weathered very calcareous; forms ledges; contains streaks of coal

123. Shale; banded gray white and light yellow brown, sandy

122. Shale, chocolate-brown, coaly; partly covered _...- 788

121. Sandstone; various shades of light yellow brown, friable, noncalcareous

120. Coal (upper split of Anderson bed); contains many upright silicified stumps as much as $10 \mathrm{ft}$ in diameter

119. Shale, brown and black, carbonaceous; has 1-in. stringers of coal, some silicified wood

118. Coal; some black carbonaceous shale

117. Shale, dark-brown to black, carbonaceous; has coal stringers less than 6 in. thick

116. Coal

115. Shale, black, carbonaceous - 12

114. Coal _-

113. Shale, light-gray-brown

112. Siltstone, light-yellow-brown to rusty-brown $\ldots-\ldots$

111. Shale, light-gray to dark-gray, fissile; locally cuts down through coal bed below

110. Coal (lower split of Anderson bed); yellow-brown silicified logs $2 \mathrm{ft}$ in diameter and $10 \mathrm{ft}$ long, coated with gypsum, are at base of coal bed

109. Shale, dark-gray-brown to light-gray-brown; some brown sandy shale

108. Shale, gray-white to light-yellow and rustybrown; some beds of rusty-brown siltstone less than 2 in. thick 
Composite stratigraphic section of the Tongue River Member of the Fort Union Formation-Continued

Fort Union Formation-Continued

Ft in.

Tongue River Member-Continued

107. Coal and soot (upper Dietz bed)

$\begin{array}{rr}1 & 5 \\ 2 & 8 \\ & \\ 1 & 7 \\ 8 & 10 \\ & \\ 3 & 2 \\ & 5 \\ & 11 \\ 5 & 10\end{array}$

106. Shale, light-brown-gray

105. Shale, chocolate-brown, somewhat coaly. plant remain

103. Sandstone, bright-yellow-brown, fine-grained, noncalcareous

102. Shale, chocolate-brown

101. Shale, black, coaly, carbonaceous

100. Coal (Dietz bed); contains bony coal

99. Shale, light-yellow-brown; has thin lenses of rusty-brown calcareous siltstone; grades upward into light-yellow friable calcareous sandstone.

98. Shale, grayish-white to light-grayish-brown; con-
tains paper-thin lenses of coal and remains of

98. Shale, grayish-white to light-grayish-brown; con-
tains paper-thin lenses of coal and remains of $\operatorname{logs} 12$ in. in diameter, $6 \mathrm{ft}$ long -

97 Shale, grayish-white to light-grayish-brown

96. Coal, sooty

95. Shale, chocolate-brown; contains plant remains ---

94. Shale, light-yellow to light-grayish-brown, sandy, calcareous; contains clastic mica, plant remains -

93. Sandstone; light gray when fresh, brown when weathered, medium grained, calcareous, crossbedded; forms ledges

92. Covered

91. Shale, chocolate-brown; contains plant remains -12

chocolate-brown; contains plant remains

90. Coal (Canyon bed) -

89. Shale, chocolate-brown to black, coaly; contains plant remains -_._- 71

88. Shale, grayish-white, calcareous _...- 20

87. Sandstone, predominantly grayish-white, partly yellowish-brown and dark-reddish-brown, shaly, calcareous

86. Sandstone, greenish-gray to grayish-brown,
medium-grained, noncalcareous

85. Shale; is various shades of light brown to gray brown and yellow brown, sandy, friable, cal-

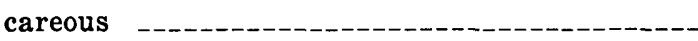

84. Shale, chocolate-brown to black, carbonaceous; one thin coal seam less than 1 in. thick; contains plant remains -

83. Covered - 
Composite stratigraphic section of the Tongue River Member of the Fort

Union Formation-Continued

Fort Union Formation-Continued

Ft in.

Tongue River Member-Continued

82. Sandstone, grayish-white to gray-brown, calcareous, friable, partly covered

81. Sandstone; light gray when fresh, large rustybrown slabs when weathered; fine to medium grained, calcareous, ripple marked; partly covered

80. Siltstone; blue gray when fresh, light rust yellow brown when weathered, calcareous

79. Shale, light-gray to grayish-brown, calcareous

78. Sandstone, light-gray to grayish-brown, finegrained, calcareous, friable

77. Shale; light brown when fresh, various shades of brown when weathered, sandy, calcareous

$5 \quad 2$

76. Clinker of Cook coal bed, chiefly altered sandstone

Tongue River Member (offset about 5 miles down Bloom Creek to hill in NE $1 / 4 \mathrm{SE}^{1 / 4}$ sec. 13 , T. 7 S., R. 48 E.) :

75. Ash of Cook coal bed

10

74. Covered with clinker rubble

73. Sandstone, very light gray, fine-grained; forms persistent white band below the clinker of Cook coal bed

72. Shale, chocolate-brown to black, carbonaceous; has coal seams less than 2 in. each; contains plant remains

71. Shale, light-gray to grayish-brown, sandy, noncalcareous

70. Sandstone, rusty-brown, fine-grained, silty, calcareous

69. Shale, light-gray and chocolate-brown; laminated owing to abundance of plant remains; contains many impressions of leaves

68. Coal

67. Shale, chocolate-brown; contains many impressions of leaves

66. Shale, gray; weathers grayish brown, noncalcareous, claylike when wet

65. Sandstone, grayish-white to light-grayish-brown, fine-grained, calcareous, crossbedded; interbedded with shale

64. Shale, grayish-brown, noncalcareous

63. Sandstone, grayish-white to grayish-brown, finegrained, noncalcareous, friable, crossbedded; contains small amounts of brown shale 
Composite stratigraphic section of the Tongue River Member of the Fort Union Formation-Continued

Fort Union Formation-Continued

Tongue River Member-Continued

62. Covered

Tongue River Member (offset southeast along top of sandstone three-fourths of a mile to hill in NW1/4 sec. 19, T. 7 S., R. 49 E.) :

61. Sandstone, light-tan, fine-grained, calcareous, crossbedded; forms ledges; persists throughout valley; forms cliff with beds 60 and 59

60. Shale; predominantly grayish white and has lightyellow-brown streaks, sandy, calcareous

59. Sandstone; light grayish white when fresh, light $\tan$ to rusty brown when weathered, partly fine grained, indistinct crossbedding, friable; forms ledges

58. Coal bed 5

57. Shale, chocolate-brown, sandy; alternates with light-gray to light-brown friable slightly calcareous sandstone

56. Shale, black; coaly in top $1 \mathrm{ft}$; contains plant remains

55. Shale, light-greenish-gray to light-grayish-brown, calcareous, sandy, friable; contains sandy beds -

54. Shale, mainly chocolate-brown; contains coal stringers and plant remains

53. Siltstone, light-rust-yellow, calcareous

52. Sandstone, grayish-brown, fine-grained, friable, calcareous

51. Shale; various shades of brown, somewhat sandy ---

50. Sandstone, grayish-white to light-grayish-brown, fine-grained, friable

49. Shale, yellowish-brown, sandy

48. Sandstone, grayish-white to reddish-brown, finegrained, noncalcareous, friable

47. Shale; various shades of light grayish brown and reddish brown

46. Clinker of Pawnee (No. 6) coal; varies in thickness -

Tongue River Member (offset along base of Pawnee clinker about half a mile southeast to hill in $\mathrm{S} 1 / 2$ sec. $19, \mathrm{~T} .7 \mathrm{~S}$., R. 49 E.):

45. Ash of Pawnee (No. 6) coal

44. Shale, dark-blue-gray to gray-black; contains a few partly baked plant remains 
Composite stratigraphic section of the Tongue River Member of the Fort

Union Formation-Continued

Ft in.

Fort Union Formation-Continued

Tongue River Member-Continued

43. Shale; various shades of gray brown and light yellow brown, in part calcareous, somewhat sandy -..---_---

42. Sandstone, gray-white to light-gray-brown, finegrained, calcareous, friable; contains a few plant remains

41. Shale; various shades of gray brown and yellow brown, calcareous, sandy

40. Sandstone, partly covered, gray-white to lightgray-brown, fine-grained, slightly calcareous, friable

39. Sandstone, light-rust-brown, fine- to mediumgrained, massive, calcareous, crossbedded _._._. 17.7

38. Clinker of No. 8 coal bed

37. Ash of No. 8 (local) coal bed above Cache bed ....- 15

36. Sandstone, grayish-white to yellowish-brown, noncalcareous, friable

35. Shale; various shades of light gray brown and light yellow brown, somewhat sandy _-_-_--- $9 \begin{array}{lll}9 & 7\end{array}$

34. Shale, chocolate-brown to gray-brown, carbonaceous; contains stringers of coal

33. Shale; various shades of light brown and light yellow brown, somewhat sandy; claylike when damp

32. Sandstone, grayish-white to very light gray brown, fine-grained, noncalcareous, friable

31. Shale, light-gray-brown, somewhat sandy; contains a few plant remains

30. Shale, chocolate-brown to black, coaly

29. Sandstone, light-gray to chocolate-brown, friable; contains plant remains

28. Sandstone, light-bluish-gray, fine-grained, nocalcareous, friable; contains some brown carbonaceous material

27. Siltstone, rust-brown to yellow-brown, calcareous, hard

26. Shale, chocolate-brown; contains a few plant remains (No. 9 or Cache coal bed)

25. Coal; exposed on north bank of Bloom Creek _-_-_- $6 \quad 7$

24. Shale, chocolate-brown; many plant remains; exposed on north bank of Bloom Creek -..--_----- 3

23. Coal 


\section{Composite stratigraphic section of the Tongue River Member of the Fort} Union Formation-Continued

Fort Union Formation-Continued

Tongue River Member-Continued

Tongue River Member (offset to SW $1 / 4$ sec. 13, T. 7 S., R.

51 E. Here No. 9 (Cache) coal bed, designated No. 8-9

bed, is $19 \mathrm{ft}$ thick, including a shale parting half an inch thick near the middle) :

22. Sandstone, buff and white 330

21. Shale, brown

20. Coal

19. Shale, black, carbonaceous

18. Shale, brown

17. Variegated shale and sandstone; much buff sandstone

Ft in.

16. Shale, brown; contains coal bed 6 in. thick _._._. $2 \quad 0$

15. Sandstone, brown to buff, shaly _._._._._-_._. $55 \quad 0$

14. Shale, brown -

13. Coal _.

12. Shale, brown

11. Variegated rocks; much purplish shale _______ $41 \quad 0$

10. Shale, brown

9. Coal _.. 26

8. Shale, brown -.-_-_-_-_- 2

7. Sandstone, buff, shaly ___ $77 \quad 0$

6. Shale, brown -...- 10

5. Coal, contact bed _..... 46

Total Tongue River Member _._. $\overline{1,481} 3$

Lower member:

4. Shale, brown 8

3. Sandstone, white; some yellow ferruginous cones -- 50

2. Sandstone, white and yellow _._._-_-_-_-_ $48 \quad 0$

1. Sandstone and drab-gray shale

\section{WASATCH FORMATION (EOCENE)}

About 200 feet of the basal part of the Wasatch Formation is present on the interstream divides in the southwestern part of the mapped area. The formation contains somber gray-brown and gray shale, some carbonaceous shale, and thin beds of brown calcareous sandstone. Clam and snail shells are so abundant in several beds of sandstone that the units have a coquinoid appearance. Most of the formation is soft and erodes readily into gentle slopes on which the beds of sandstone form small ledges. Few trees grow on the formation. A stratigraphic section of the lowermost 
176 feet of the Wasatch Formation in secs. 21 and 26, T. 9 S., $\mathrm{R} 45 \mathrm{E}$., is given below.

Wasatch Formation (lowermost 176 feet) in secs. 21 and 26 , T. 9 S., R. $45 E$.

[Measured by W. H. Hass]

Wasatch Formation:

Clinker at top of hill and ash at base; contains leaves

Shale, somber brown and gray; partly covered; lens of siltstone 5 in. thick $5 \mathrm{ft}$ above base

Siltstone, light-yellow-brown to rust-brown, calcareous; weather hackly

Sandstone, light-yellow-brown to grayish-white, fine-grained, friable

Shale, light-brown and grayish-brown, partly exposed

Siltstone, rust-brown, calcareous

Shale, chocolate-brown, laminated ; contains plant fragments --

Shale, light-brown and gray-brown; mostly concealed

Siltstone, light-yellow-brown

Sandstone, light-yellow-brown to grayish-white, finegrained, calcareous, friable

Covered; partly exposed brown shale and light-brown fri-

able sandstone

Shale, chocolate-brown, laminated

Shale, dark-grayish-brown

Sandstone; various shades of light yellow brown, friable

Shale, dark-chocolate-brown to black, carbonaceous -...-...-

Covered; some brown shale exposed

Sandstone, light-brown to grayish-white, friable; in part concealed

Siltstone, yellow-brown, calcareous

Shale, light-brown to light-gray; poorly exposed _-..-_-_- 80

Shale, dark-gray to black, carbonaceous; poorly exposed _...- $\quad 2 \quad 1$

Coal

Shale, chocolate-brown to black, carbonaceous; contains plants

Sandstone, grayish-white to light-grayish-brown, calcareous, friable; contains a few 1-in.-thick beds of rust-brown siltstone; contains fresh-water clams and snails, mostly in fragments

Shale, chocolate-brown; contains plant remains

Sandstone, light-grayish-brown, calcareous, friable

Sandstone, light-grayish-brown, medium-grained, calcareous; weathers rusty brown; forms ledge; contains clams and snails 
Wasatch Formation (lowermost 176 feet) in secs. 21 and 26 , T. 9. S., R. 45 E.-Continued

Wasatch Formation-Continued

Interval partly concealed; mainly light-yellow-brown sandstone; contains clams and snails

Sandstone, light-gray-brown, medium-grained, calcareous; weathers rust brown; contains clams and snails

Sandstone, very light gray to yellow-brown, fine-grained, calcareous

Siltstone, light-yellow-brown, very calcareous; forms a ledge; coquina of fresh-water clams and snails

Shale, light-gray and yellow-brown; contains plant remains -- $8 \quad 10$ Fort Union Formation:

Roland coal bed.

The boundary between the Fort Union (Paleocene) and Wasatch (Eocene) Formations, as used by Thom and Dobbin (1924, p. 495) and as used in this report, is drawn at the top of the Roland coal bed; it conforms to the boundary used by Baker (1929) in the northern extension of the Sheridan coal field adjacent to the mapped area on the west and by Olive (1957) in the northern part of the Spotted Horse coal field, Wyoming, adjacent to the south. There seems to be no difference in the rocks directly below and directly above this boundary in the Moorhead coal field or in the northern extension of the Sheridan coal field, according to Baker (1929, p. 28). Many fossils were collected in the Moorhead coal field in an effort to date the Fort Union-Wasatch boundary more precisely.

These collections, and all others available from the Powder River Basin, have been reviewed by D. W. Taylor (written commun., 1968). Distinctive Wasatch and Fort Union faunas are readily recognizable throughout the region. The fossil evidence supports previous interpretations that the Wasatch Formation is separated from the Fort Union by an erosional unconformity, which is scarcely discernible in the center of the basin but which is evident at the margins where the Fort Union has been titled more strongly. The unconformity at the base of the Wasatch is above the Arvada coal bed, about 100 feet above the Roland coal bed in the southwestern part of the Moorhead area. Correlation with adjacent areas indicates that the unconformity is of late earliest Eocene age (late Gray Bull age of Wood and others, 1941). 


\section{QUATERNARY SYSTEM}

\section{PLEISTOGENE(?) DEPOSITS}

Terrace gravel covers small areas in places along the Powder and Little Powder Rivers at several levels above present drainage. Several terrace remnants are near the abandoned town of Moorhead in T. 9 S., Rs. 47 and 48 E., where the valley of the Powder River is narrow and the sides of the valley abruptly rise several hundred feet. Erosion has not widened the valley sufficiently to destroy the terrace remnants. The elevations above the Powder River at which the terrace remnants occur are: 300 feet for the large areas in secs. 17,18 , and 20 , T. 9 S., R. 48 E.; 170-180 feet for the small areas in the $\mathrm{S} 1 / 2$ sec. 19 and the $\mathrm{N} 1 / 2 \mathrm{~N} 1 / 2$ sec. 30., T. 9 S., R. 48 E.; 130 feet for the small area near the center of the N1/2 sec. 25, T. 9 S., R. 47 E.; 160 feet for the small area in the NW $1 / 4, \mathrm{SE} 1 / 4$, sec. $24, \mathrm{~T}, 9 \mathrm{~S} ., \mathrm{R} .47 \mathrm{E} . ; 265 \pm$ feet for the elongate area in the $\mathrm{N} 1 / 2 \mathrm{~N} 1 / 2$ sec. 8 , T. 9 S., R. 48 E.; 180 feet for the small area on the north line of the NE1/4 sec. 5, T. $9 \mathrm{~S}$, R. $48 \mathrm{E}$.; and 250 feet for the remnants farther downstream in the $\mathrm{S} 1 / 2$ sec. 1 , T. 8 S., R. $48 \mathrm{E}$.

A few small remnants of terrace deposits are widely spaced farther down the Powder River. Those in T. 6 S., R. 50 E., are 80 feet above the river bed in the SW $1 / 4, S E 1 / 4$ sec. 28,150 feet in the NW $1 / 4, \mathrm{SW}^{1} / 4 \mathrm{sec}$. 23, and 105 feet near the center of the $\mathrm{S} 1 / 2 \mathrm{SW} 1 / 4$, sec. 14 . The several remnants in T. 6 S., R. $51 \mathrm{E}$., near the corner common to secs. $5,6,7$, and 8 , are 75 feet above the river bed and the gravel is about 10 feet thick. In T. 5 S., R. 51 E., small remnants of a gravel deposit 65 feet thick in secs. 9 and 10 are 60 feet above the river bed. This deposit was quarried for road material several years ago.

Several remnants of high terrace gravel are present in R. $52 \mathrm{E}$. Two remnants of a high terrace gravel occur in the SE1/4, sec. 6 and the NE1/4, sec. 7, T. 5 S., on the divide between the Powder and Little Powder Rivers, 360 feet above the bed of the Powder River. These deposits are about 20 feet thick. Two small remnants in the SE1/4 sec. 3, T. 7 S., west of the Little Powder River, are 235 feet above the river. Patches of gravel are present 130 feet above the river farther south, west of the Little Powder River, in secs. $3,9,10,15,22$, and $27, \mathrm{~T}$. $8 \mathrm{~S}$. This deposit is 10 feet or more thick and has been quarried for road material. The small terrace gravel remnants near the SE. cor. sec. 33 are 10-20 
feet thick and are 260 feet above the river. Three small gravel deposits about 150 feet above the river bed are present on the east side of the Little Powder River in secs. 27 and 28, T. $9 \mathrm{~S}$.

The gravel is composed largely of fragments of clinker and sandstone derived locally, but much of the higher gravel contains fragments of metamorphic and igneous rocks foreign to the area. Much of the locally derived material consists of poorly sorted flat round-edged pebbles that are commonly about $1-11 / 2$ inches long. In places, however, boulders of locally and foreign derived rock are more than 1 foot in diameter. The foreign rock material is more rounded than the local material.

\section{HOLOCENE DEPOSITS}

Wide belts of alluvium occupy the flood plains of the Powder and Little Powder Rivers. Narrower belts are present along all the larger tributaries to these rivers and along the principal streams in the western part of the mapped area. The alluvium is composed of silt, very fine sand, and local lenses of gravel. The width of the belt of alluvium on the Powder River generally ranges from less than half a mile near the southern boundary of the mapped area to more than 2 miles in the northeastern part. The width of the belt of alluvium along most of the course of the Little Powder River northward across the coal field is one-half to threefourth mile. The Little Powder and Powder Rivers have cut their meandering courses about 15 feet below the surface of the flood plains.

Relatively narrow belts of alluvium are present along the courses of all the major tributaries. Such belts are particularly well developed along Baking Powder, Butte, Buttermilk, and Bay Horse Creeks southeast of the Powder River where the rocks dip downstream and along Taylor, Indian, Bradshaw, Bear, and Lee Creeks in the western part of the area. All these tributary streams have cut their channels 10-15 feet below the alluvium surface.

\section{STRUCTURE}

Regionally, the coal field is on the northeastern flank of the Powder River Basin, which is a major structural feature in northeastern Wyoming and part of southeastern Montana (U.S. Geological Survey and American Association of Petroleum Geologists, 1961). Detailed mapping of the structure of the exposed rocks was not included in the investigation. The attitude of the rocks underlying the coal field was determined by the preparation of a 
structure contour map (not reproduced here) drawn on the Upper Cretaceous Eagle Sandstone; the rocks were identified on the electrical logs of wells drilled prior to 1963 for oil and gas in and near the mapped area. The strike of the rocks is about due north in the easternmost tier of townships of the coal field and slightly west of north in the next two tiers on the west. Thence, farther west the strike swings more to the west; it is nearly due northwest in Tps. 7 and 8 S., Rs. 44 to 47 W., and is west in T. 7 S., R. $43 \mathrm{~W}$. The amount of dip westward in the easternmost townships is as much as 75 feet per mile and, except for T. 7 S., R. $43 \mathrm{~W}$., where the dip is southward, decreases to about $40-50$ feet per mile southwestward throughout much of the rest of the area.

A westward dip is readily observed in the exposed rocks in the part of the area lying east of the Powder River; it is particularly evident in the exposures of sandstone beds and clinker on the northeastern slopes of Bay Horse, Butte, and Baking Powder Creeks and the other tributaries of the Powder River. The westward dip is also evident in the barren slopes bordering the eastern tributaries of the Little Powder River. The prevalence of artesian water flows in many wells in the Powder River and Little Powder River valleys is due to the westward dip of the rocks from high areas in the eastern part of the mapped area. The regional strike and dip of the exposed rocks in the central and western parts of the mapped area are not so easily observed because of the decrease in the rate of dip.

Some small local folds were observed, and some faults were mapped in the exposed rocks. An anticline whose flanks dip gently exposes the Anderson clinker in parts of secs. 20, 21, 28, and 29, T. 9 S., R. 44 E., and a dry hole was drilled in sec. 29 in the search for oil or gas. In the southwestern part of the mapped area several normal faults, which trend generally slightly north of east for distances of up to 7 miles, displace the exposed rocks. Except for short faults in secs. 1 and 12 and faults where the rocks are dropped down on the northwest in secs. 14, 22, and 23 , the relative displacement of the rocks along the faults ranges from 50 to 200 feet down on the southeast.

\section{ECONOMIC GEOLOGY \\ OIL AND GAS}

The Moorhead coal field is near the northern end of the Powder 
River Basin, which is a major oil province in the Rocky Mountain region. Oil has been produced from Cretaceous rocks for many years in many fields in the Wyoming part of this basin. Small amounts of gas are produced from eight wells at a depth of about 3,000 feet in the Pumpkin Creek field in Montana, 18 miles northwest of the northeastern margin of the mapped area. Production of the gas is from the Shannon Sandstone Member of the Steele Shale (Parker, 1958) of Late Cretaceous age.

The shallow rocks, at depths of generally less than 7,500 feet in the Moorhead coal field, include possible oil- or gas-bearing sandstones in the Sundance and Morrison Formations of Late Jurassic age; the Lakota, Fall River, Dakota, and Newcastle Formations of Early Cretaceous age; several sandstones equivalent to the Upper Cretaceous Frontier Formation; and the Shannon and Sussex Sandstone Members of the Steele Shale and the Parkman and Teapot Sandstone Members of the Mesaverde Formation of Late Cretaceous age (Parker, 1958; Strickland, 1958). Many of the oil and gas pools in these sandstones in eastern Wyoming are in stratigraphic traps, some of which are associated with structural features such as anticlines or domes. The sandstones generally diminish in thickness or pinch out eastward across the Powder River Basin.

At ieast 21 oil pools were discovered during the period 1960-63 (Trotter, 1963, p. 120) in the northern part of the Powder River Basin in Wyoming in the Minnelusa Formation of Pennsylvania and Permian age. Of these, the northernmost one, the Rocky Point pool, is only 10 miles southeast of the southeastern corner of the Moorhead coal field. These oil discoveries were the result of active exploratory drilling carried on throughout the Wyoming and Montana parts of the basin.

Beds of sandstone commonly form the oil reservoirs in the Minnelusa Formation; facies changes from sandstone to dolomite and porosity pinchouts caused by secondary precipitation of anhydrite form the traps in some fields (Trotter, 1963, p. 120). Generally, the sandstones are at or near the eroded top of the formation, and leaching of the cementing material in them has increased their porosity. Many of the major irregularities on the Minnelusa surface seem to have been caused by differential erosion of hard and soft beds of the Minnelusa on the crests of anticlines and along the outcrop of the formations on the regional west-dipping monocline prior to burial by the overlying Permian 
Opeche Shale. Consequently, detailed maps showing the thickness of the Opeche Shale combined with subsurface structure contour maps and thickness maps of the Minnelusa Formation aid in locating sites for drilling wells (Trotter, 1963, p. 122). Thin linear belts of Opeche Shale which alternate with thick belts may indicate the presence of sandstone at the top of the Minnelusa. Seismograph surveys are used to aid in locating fluctuations in the thicknesses of the Opeche Shale and the Minnelusa Formation and in detecting local structural features. Exploratory wells in that part of Wyoming which contains the oil pools in the Minnelusa Formation have a discovery ratio of about $1: 10.4$ wells drilled, according to Trotter (1963, p. 122).

A thick column of sedimentary rocks underlies the top of the Minnelusa Formation in and near the mapped area. The Gulf Oil Corp. Bales 1, drilled in 1962 in the center NE1/4 NW1/4 sec. 11, T. 9 S., R. 45E., in the southwestern part of the Moorhead coal field, penetrated a sequence of beds 1,950 feet thick below the top of the Minnelusa and bottomed 4 feet below the top of the Deadwood Formation of Cambrian and Ordovician age. The Gulf Oil Corp. Boyle 1, drilled in 1952 in the SW1/4 NW1/4 SE1/4, sec. 4, T. 8 S., R. 52 E., in the southeastern part of the area, penetrated a similar sequence of beds 2,108 feet thick and bottomed 18 feet below the top of the Deadwood Formation. A third deep well, Mobil Producing Co. F43-3NP, drilled in 1956 in the center NE1/4.SE1/4 sec. 3, T. 4 S., R. 44 E., 17 miles north of the western part of the mapped area, penetrated a similar sequence of beds 2,082 feet thick and bottomed 72 feet below the top of the Winnipeg Formation of Middle Ordovician age-a few feet above the top of the Deadwood Formation (Sandberg, 1962, figs. 6, 8).

This pre-Permian sequence consists, in descending order, according to lithologic logs of the wells prepared by the American Stratigraphic Co. (Denver, Colo.), of about 400 feet of interbedded gray to white dolomite, gray sandstone, and green to gray shale of Pennsylvanian age, unconformably overlying slightly less than 1,000 feet of gray and brown dolomite, minor amounts of buff limestone including the Charles, Mission Canyon, and Lodgepole Formations of Mississippian age; unconformably overlying in the Mobil well (absent from the Gulf Boyle 1) 113 feet of creamcolored dolomite of Devonian age; unconformably overlying dolomite of Silurian age similar to that above and slightly more than 100 feet thick; unconformably overlying 400 feet of buff to gray- 
brown dolomite which in turn overlies 50-90 feet of white sandstone both of which are of Ordovician age (Richards and Nieschmidt, 1961); unconformably overlying white sandstone of Cambrian age. Neither well penetrated the Ordovician and Cambrian (Deadwood Formation) sandstone, but regional data suggest that the sandstone is $800-1,000$ feet thick and that it overlies crystalline rock of Precambrian age (Sandberg, 1962, figs. 6, 7).

The following stratigraphic section of pre-Permian rocks is a composite of lithologic logs of wells prepared by the American Stratigraphic Co. (Denver, Colo.):

Pennsylvanian:

Feet

9. Dolomite, interbedded gray to white, gray sandstone, and green to gray shale -..--

Unconformity.

Mississippian:

$\left.\begin{array}{l}\text { 8. Dolomite, gray and brown } \\ \text { 7. Limestone, buff; includes the Charles, Mission Canyon, } \\ \text { and Lodgepole Formations }\end{array}\right\}<1,000$

Unconformity. and Lodgepole Formations _-

Devonian:

6. Dolomite, cream-colored; in the Mobil well (absent from the Gulf Boyle 1)

Unconformity.

Silurian:

5. Dolomite; similar to unit 6

Unconformity.

Ordovician: ${ }^{1}$

4. Dolomite, buff to gray-brown

3. Sandstone, white

Unconformity.

Ordovician and Cambrian: ${ }^{2}$

2. Sandstone, white; Deadwood Formation (regional data) $-800-1,000$ Precambrian:

1. Rock, crystalline.

1 Richards and Nieschmidt (1961).

2 Sandberg (1962, figs. 6, 7 ).

The average depth of exploratory wells drilled in and near the mapped area has increased since 1959. Prior to 1960, the principal objective for most wells was the testing of the Parkman Member of the Mesaverde Formation and Sussex and Shannon Members of the Steele Shale between depths of about 3,000 and 5,500 feet; a few deep wells reached the Dakota Sandstone at a depth of about 
5,000 feet, and a few tested the Morrison Formation between the depths of about 5,500 and 7,500 feet. Of 27 wells drilled prior to 1960 in the mapped area and in a belt of country about 6 miles bordering it in Montana, ${ }^{1} 16$ reached the Parkman, the Sussex, or the Shannon; five reached the Morrison, and one reached the Minnelusa. Of a total of 28 wells drilled during 1960-63, however, two penetrated only the Parkman, Sussex, and Shannon; two reached the Dakota, 10 reached the Morrison, and 14 reached the Minnelusa between depths of 6,800 and 8,700 feet. Eleven wells were drilled during 1962-63, and all tested the Minnelusa. Only two wells-one in the western part and one in eastern part of the coal field-penetrated the 2,000-foot-thick carbonate sequence that underlies the top of the Minnelusa Formation. One was drilled in 1952 ; the other, in 1962.

\section{CLINKER}

Except for the northeastern and the easternmost parts of the coal field, clinker formed by the burning of coal beds along their outcrops is widespread. It is widely used for surfacing local roads. Although it is not as durable as gravel obtained from river beds and from terrace deposits, the proximity of the clinker to the places where it is used gives it an advantage over other materials in most of the area.

\section{COAL}

The investigation revealed the presence of about 30 beds of coal, which are distributed through a stratigraphic sequence slightly more than 2,000 feet thick. A few thin beds of coal are in the lower member of the Fort Union Formation, many thick and many thin beds are in the Tongue River Member, and a few thin beds are in the lower part of the Wasatch Formation. Only coal beds that were at least 2 feet thick were mapped. Wherever the thickness of a bed diminishes to less than 2 feet, the bed is not shown on the map; the outcrop of a coal bed that may be traced for many miles may not be shown on the map for this reason. This condition was observed at many places in the area

\footnotetext{
1 The Bell Creek oil field was discovered in the Montana part of the Powder River Basin in 1967 (after this report was written) in the Cretaceous Muddy Sandstone Member of the Thermopolis Shale. The oil field is 15 miles long and from $1 / 2$ to $31 / 2$ miles wide and extends 15 miles northeastward from sec. 32 , T. 9 S., R. 53 E., which is only $1 \frac{1 / 2}{2}$ miles east of the mapped area of the coal field. It is ranked as a giant oil field, whose cumulative production is $30,600,000$ barrels and whose reserve is estimated to be $83,600,000$ barrels as of 1970 (Oil and Gas Journal, Jan. 26, 1970, p. 132).
} 
occupied by the lower member of the Fort Union inasmuch as many of its coal beds are thin and lenticular. An attempt was made to correlate many of the lenses of coal in the lower member from place to place, but precise correlations were impossible because of the thinness and lenticularity of the beds.

The approximate stratigraphic position of the principal coal beds is shown on plate 2. Many individual beds of coal in the Tongue River Member are thick and persist for many miles. The outcrops of zones of baked rock, so-called clinker, were mapped throughout most parts of the coal field. Most of the coal sections were measured in gulches where unburned coal is exposed. It is impossible to be certain whether a single coal bed persists from gulch to gulch or whether the outcrops represent several closely associated coal beds; therefore, the skeleton columnar sections (pl. 2) show the relative stratigraphic position of the principal coal beds or zones. The thickness of intervals between beds as mapped varies considerably from township to township, especially in the area east of the Powder River. Accordingly, considerable discrepancy exists between total thickness of the members in the stratigraphic sections described in the text and the skeleton sections shown on plate 2 .

\section{PHYSICAL AND CHEMICAL PROPERTIES}

Fresh coal in the field is black, shiny, and hard. The coal slacks rapidly when exposed to the air; therefore, it cannot be stored in open piles for long periods or shipped a long distance in open cars. Table 2 shows analyses of 10 samples of coal, of which six are from core holes at the Moorhead damsite in sec. 19, T. $9 \mathrm{~S}$., R. $48 \mathrm{E}$., three are from mines near Broadus, and one is from the Two Trees mine 15 miles northwest of Broadus. The analyses were made by the U.S. Bureau of Mines in its Pittsburgh, Pa., laboratory. Based on these analyses the rank of the coal near Broadus is lignite $\mathrm{A}$, and the rank of the coal from the core holes and from the Two Trees mine in sec. 15, T. 4 S., R. 48 E., is subbituminous-C. The average heating value of "as received" coal from the core holes is 8,515 Btu (British thermal units), and the average for the coal from the three mines near Broadus is $7,297 \mathrm{Btu}$. The heating value for determining the rank of the coal, however, is calculated on a moist, mineral-matter-free (American Society for Testing and Materials, 1966). Accordingly, the heating value of the coal from the core holes in secs. 18 and 19, T. 9 S., R. 48 E., is $9,013 \mathrm{Btu}$ and that from the three mines 


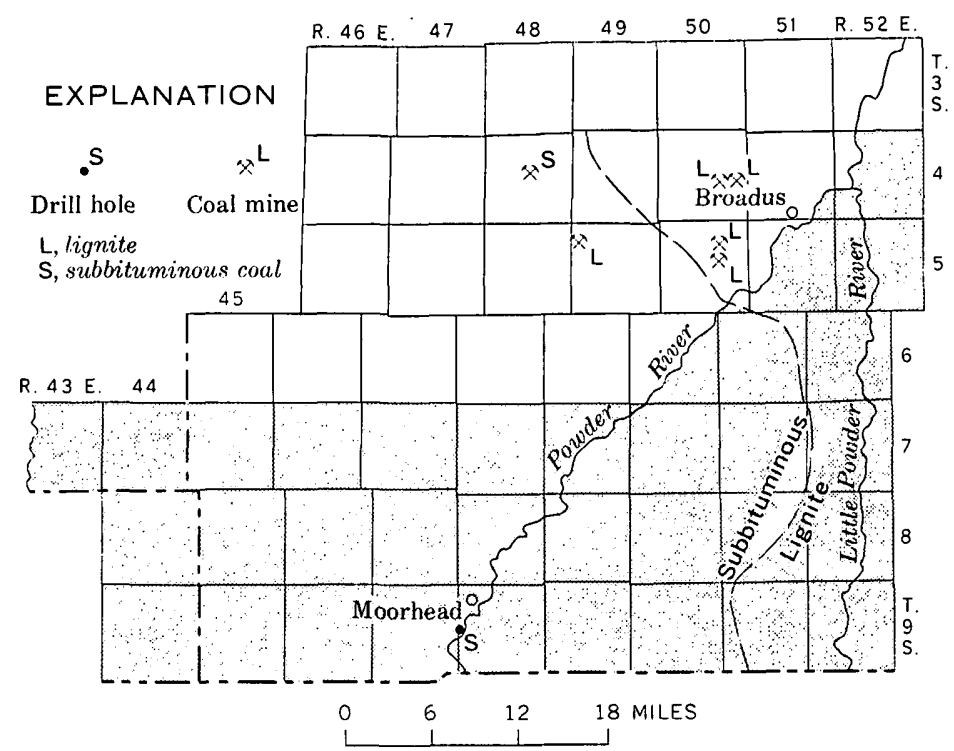

Figure 2.-Map showing Moorhead coal field, Montana, and boundary between subbituminous coal and lignite coal (from Trumbull, 1959).

near Broadus is 7,470 Btu. A regional investigation of the character of the coal in eastern Montana shows that coal increases in hardness gradually westward. The boundary between lignite and subbituminous coal passes slightly west of north through the eastern part of the Moorhead field. Inasmuch as the change from one rank to another is gradational, the boundary represents a broad belt of country rather than a sharply defined line. Its position as shown in figure 2 is adapted from the coal map of the United States by Trumbull (1959); the position of the boundary shown by Trumbull is based on the analyses of many coal samples from Powder River County and counties adjacent to it. The moisture content of the coal decreases at a rate of about 1 percent in each 11 miles southwestward in this part of Montana, according to a regional map prepared by the senior author but not reproduced here.

\section{UTILIZATION}

Virtually none of the coal of the Moorhead coal field was being mined in 1963. Ranchers find it more economical to drive to 


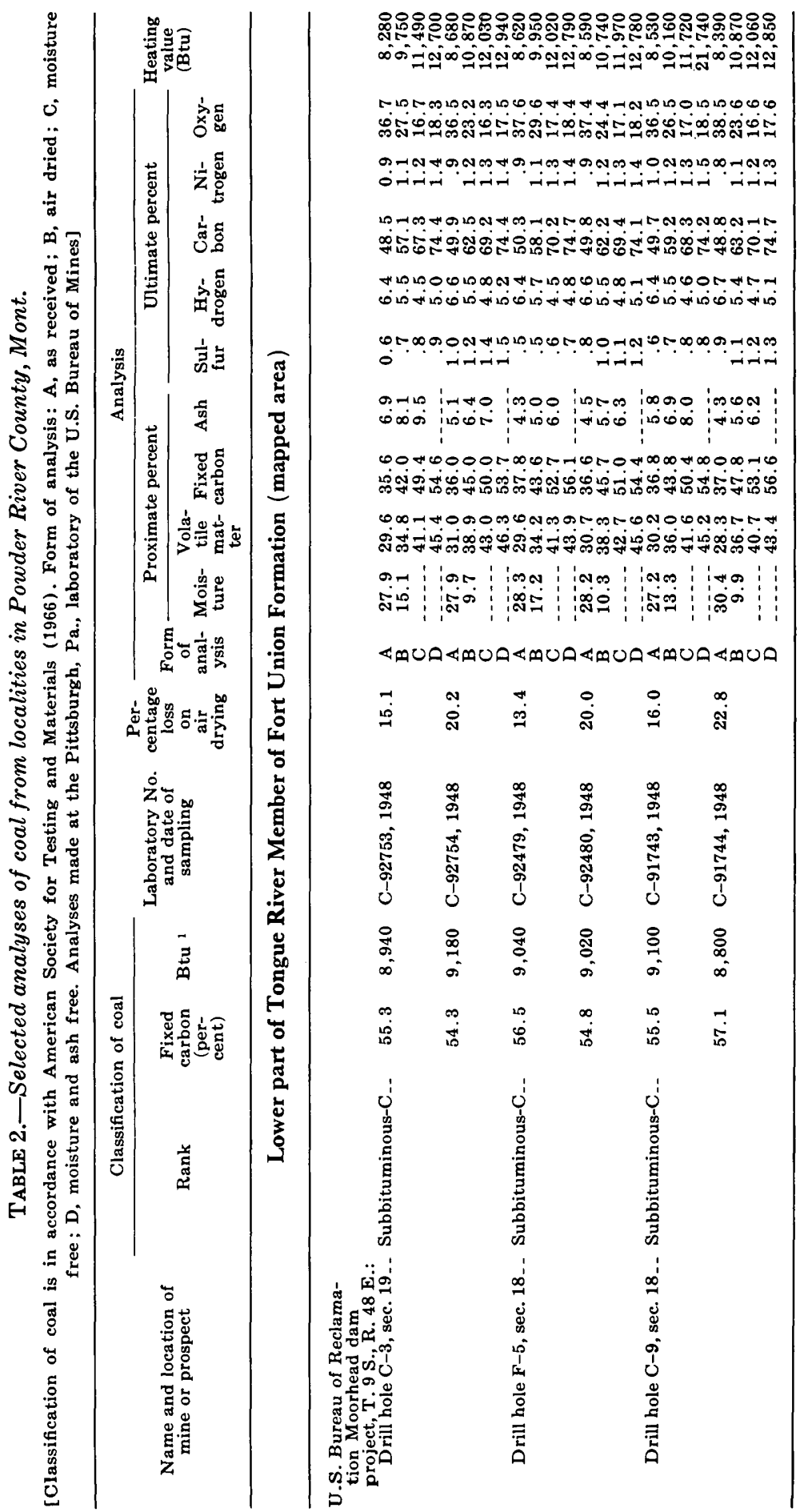




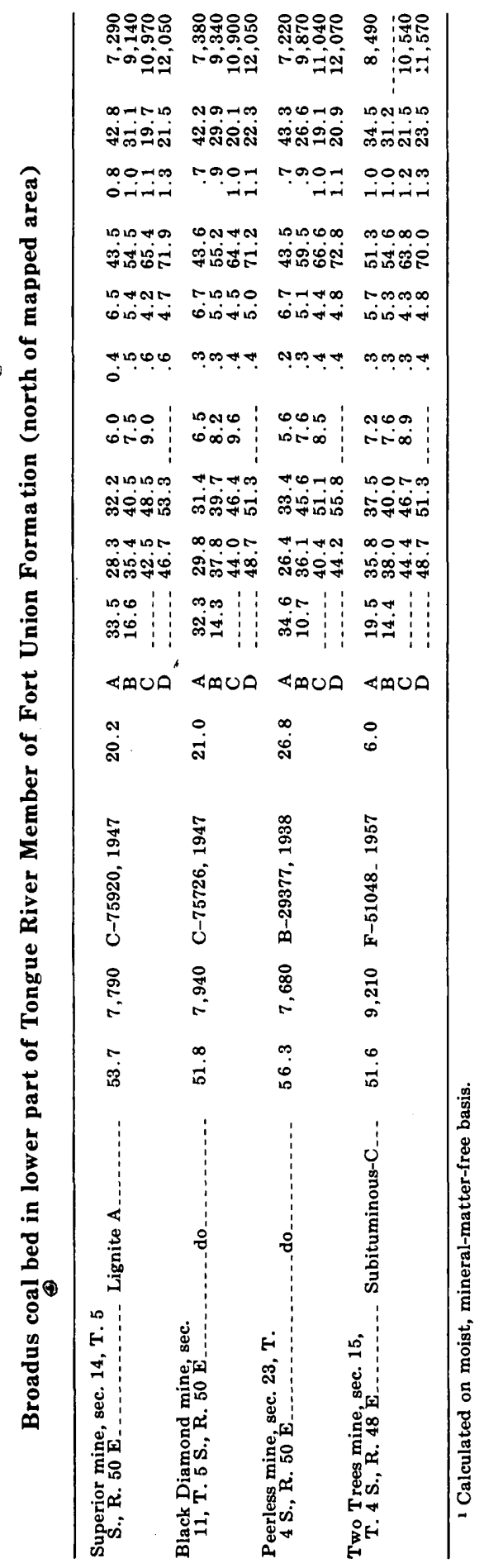


Gillette, Wyo., where a large-scale strip mine is in operation, to obtain coal or they can find it more economical to have coal delivered, 5-7 tons at a time, from Gillette to their ranches than to mine the local coal. Most ranch homes are supplied with liquid petroleum gas for cooking and electricity for appliances and use coal only for heating.

\section{ESTIMATE OF COAL RESERVES}

As calculated by the method used by the U.S. Geological Survey, the total reserves of coal in beds 2 feet or more thick in the mapped area are $21,591,100,000$ tons, of which $108,000,000$ tons is lignite and $21,483,100,000$ tons is of subbituminous-C rank. The reserves are reported in table 3 by townships and by two main categories: (1) measured and indicated and (2) inferred and, under each of these categories, by coal bed, by area in acres, and by four bed thicknesses. The thickness of a bed in an area was interpolated from measurements of the thickness at many localities; each locality has a number ( $\mathrm{pl} .1$ ) which corresponds to the number shown at the tops of graphic plots of the coal beds in figures 3-9 and plates 3-6. The length of outcrop of a given coal bed, having a thickness within the limits of one of the four thickness categories shown in table 3 , was considered to define the limits of the coal as being a semicircular area extending back from the outcrop and having a radius equal to half the length of the line of outcrop. Each area so constructed was measured by planimeter. The inferred reserves include the coal lying more than 2 miles back from the line of outcrop. The tonnages were calculated by assuming that the weight of 1 acre-foot of coal is 1,770 short tons (Combo and others, 1949, p. 17). The maximum depth of the coal shown in the reserve tables is 800 feet in T. 9 S., Rs. 44 and 45 E.; reserves for this area are 3,797,000,000 tons. The maximum depth elsewhere in the field is less than 650 feet, and much of the depth is less than 500 feet.

TABLE 3.-Estimated reserves of coal in the Moorhead coal field, Montana, by township

[Measured and indicated reserves (italic numbers) and inferred reserves (roman numbers), in millions of short tons]

\begin{tabular}{|c|c|c|c|c|c|c|}
\hline \multirow[b]{2}{*}{ Bed } & \multirow[b]{2}{*}{$\underset{(\text { feet })}{\text { Thickness }}$} & \multirow[b]{2}{*}{$\begin{array}{c}\text { Area } \\
\text { (acres) }\end{array}$} & \multicolumn{4}{|c|}{ Reserves } \\
\hline & & & $\begin{array}{c}\text { Beds } \\
2-2.5 \text { feet } \\
\text { thick }\end{array}$ & $\begin{array}{l}\text { Beds } \\
2.5-5 \text { feet } \\
\text { thick }\end{array}$ & $\begin{array}{c}\text { Beds } \\
5-10 \text { feet } \\
\text { thick }\end{array}$ & $\begin{array}{c}\text { Beds } \\
>10 \text { feet } \\
\text { thick }\end{array}$ \\
\hline
\end{tabular}

T. 7 S., R. $43 \mathrm{E}$.

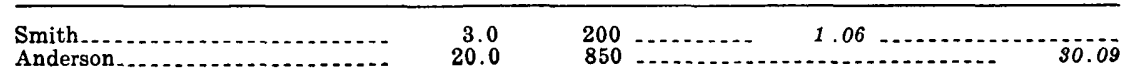


TABLE 3.-Estimated reserves of coal in the Moorhead coal field, Montana, by township-Continued

\begin{tabular}{|c|c|c|c|c|c|c|}
\hline \multirow[b]{2}{*}{ Bed } & \multirow{2}{*}{$\begin{array}{c}\text { Thickness } \\
\text { (feet) }\end{array}$} & \multirow{2}{*}{$\begin{array}{c}\text { Area } \\
\text { (acres) }\end{array}$} & \multicolumn{4}{|c|}{ Reserves } \\
\hline & & & $\begin{array}{c}\text { Beds } \\
2-2.5 \text { feet } \\
\text { thick }\end{array}$ & $\begin{array}{l}\text { Beds } \\
2.5-5 \text { feet } \\
\text { thick }\end{array}$ & $\begin{array}{c}\text { Beds } \\
\text { 5-10 feet } \\
\text { thick }\end{array}$ & $\begin{array}{c}\text { Beds } \\
>10 \text { feet } \\
\text { thick }\end{array}$ \\
\hline
\end{tabular}

T. 7 S., R. 43 E.-Continued

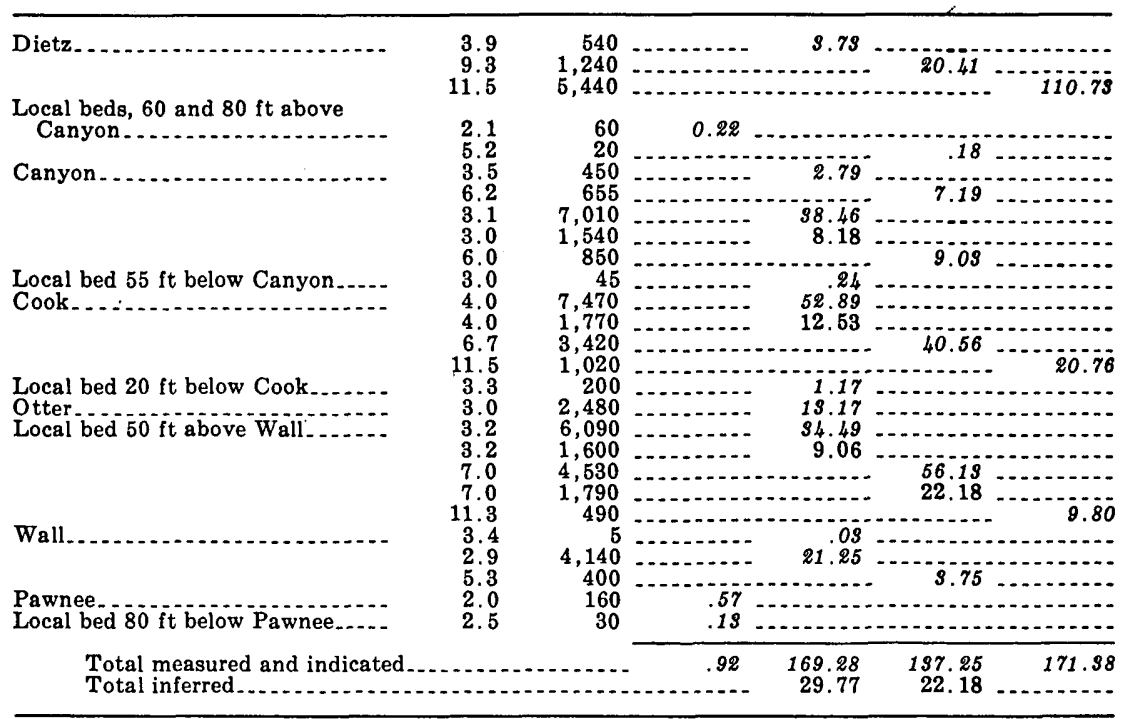

\section{T. 7 S., R. 44 E.}

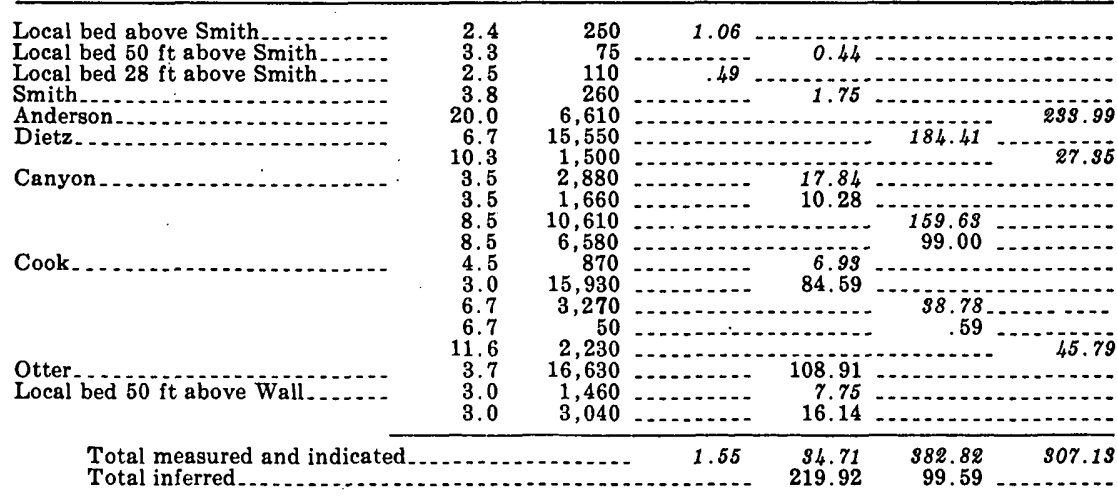

T. 8 S., R. 44 E.

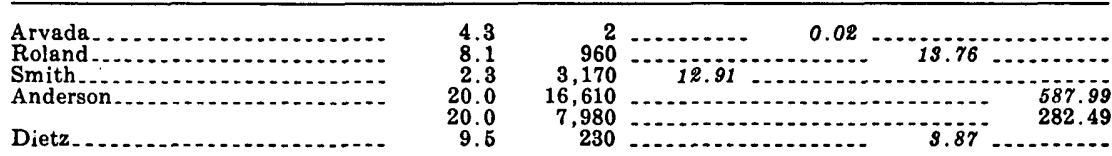


TABLE 3.-Estimated reserves of coal in the Moorhead coal field, Montana, by township-Continued

\begin{tabular}{|c|c|c|c|c|c|c|}
\hline \multirow[b]{2}{*}{ Bed } & \multirow{2}{*}{$\begin{array}{c}\text { Thickness } \\
\text { (feet) }\end{array}$} & \multirow{2}{*}{$\begin{array}{c}\text { Area } \\
\text { (acres) }\end{array}$} & \multicolumn{4}{|c|}{ Reserves } \\
\hline & & & $\begin{array}{c}\text { Beds } \\
2-2.5 \text { feet } \\
\text { thick }\end{array}$ & $\begin{array}{c}\text { Beds } \\
2.5-5 \text { feet } \\
\text { thick }\end{array}$ & $\begin{array}{c}\text { Beds } \\
5-10 \text { feet } \\
\text { thick }\end{array}$ & $\begin{array}{c}\text { Beds } \\
>10 \text { feet } \\
\text { thick }\end{array}$ \\
\hline
\end{tabular}

T. 8 S., R. 44 E.-Continued

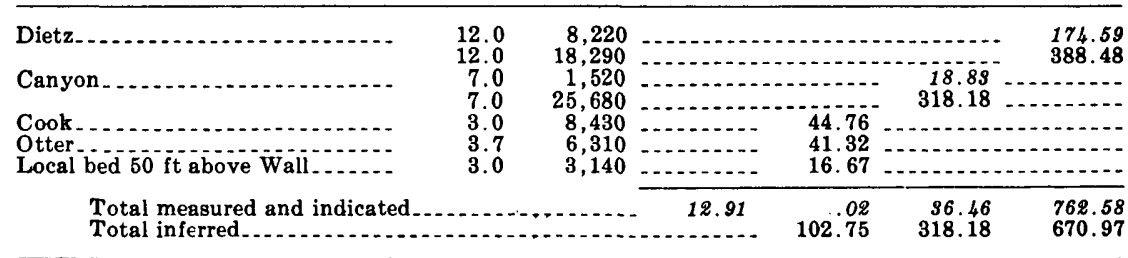

T. 9 S., R. 44 E.

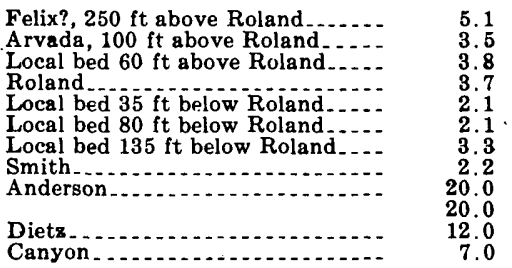

Total measured and indicated. 7.0

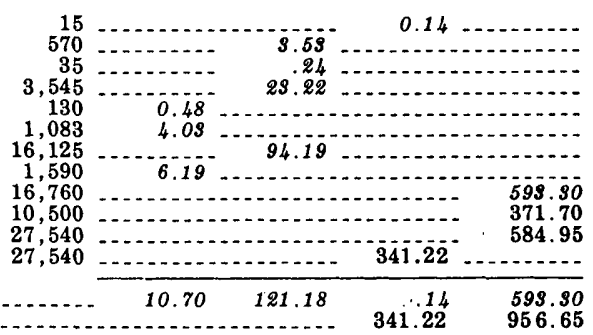

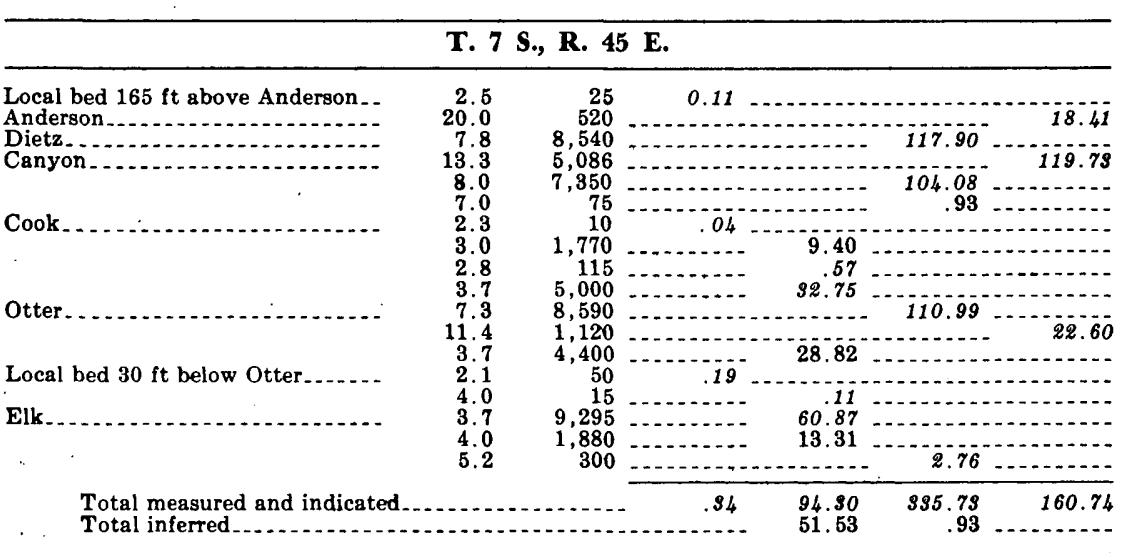

\section{T. 8 S., R. 45 E.}

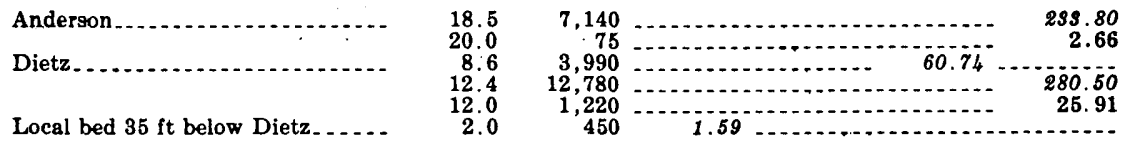


TABLE 3.-Estimated reserves of coal in the Moorhead coal field, Montana, by township-Continued

\begin{tabular}{|c|c|c|c|c|c|c|}
\hline \multirow[b]{2}{*}{ Bed } & \multirow{2}{*}{$\begin{array}{c}\text { Thickness } \\
\text { (feet) }\end{array}$} & \multirow{2}{*}{$\begin{array}{c}\text { Area } \\
\text { (acres) }\end{array}$} & \multicolumn{4}{|c|}{ Reserves } \\
\hline & & & $\begin{array}{c}\text { Beds } \\
2-2.5 \text { feet } \\
\text { thick }\end{array}$ & $\begin{array}{c}\text { Beds } \\
2.5-5 \text { feet } \\
\text { thick }\end{array}$ & $\begin{array}{c}\text { Beds } \\
5-10 \text { feet } \\
\text { thick }\end{array}$ & $\begin{array}{c}\text { Beds } \\
>10 \text { feet } \\
\text { thick }\end{array}$ \\
\hline
\end{tabular}

T. 8 S., R. 45 E.-Continued

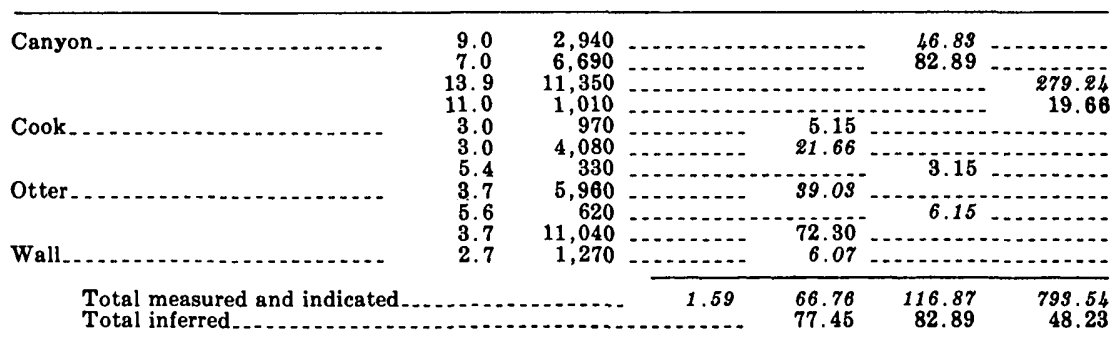

\section{T. 9 S., R. 45 E.}

\begin{tabular}{|c|c|}
\hline Arvada & 4.1 \\
\hline Roland ... & $\begin{array}{r}2.9 \\
6.6 \\
10\end{array}$ \\
\hline $\begin{array}{l}\text { Local bed } 80 \mathrm{ft} \text { below Roland..... } \\
\text { Local bed } 135 \mathrm{ft} \text { below Roland.... }\end{array}$ & $\begin{array}{l}2.3 \\
2.1 \\
3.3 \\
3.3\end{array}$ \\
\hline Anderson & $\begin{array}{l}11.4 \\
20.0\end{array}$ \\
\hline Dietz & $\begin{array}{l}11.0 \\
12.0\end{array}$ \\
\hline Canyon $\ldots \ldots \ldots$ & $\begin{array}{r}11.0 \\
7.0\end{array}$ \\
\hline
\end{tabular}

Total measured and indicated.. Total inferred.

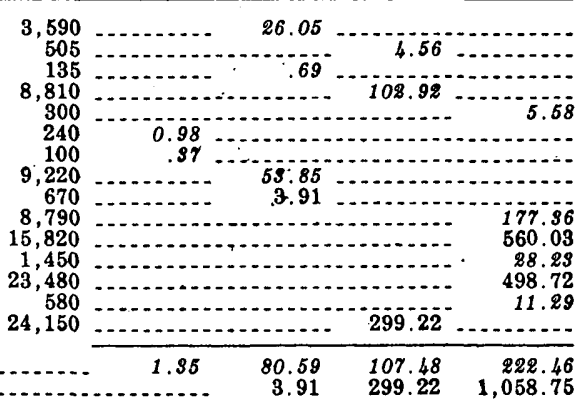

\section{T. 7 S., R. 46 E.}

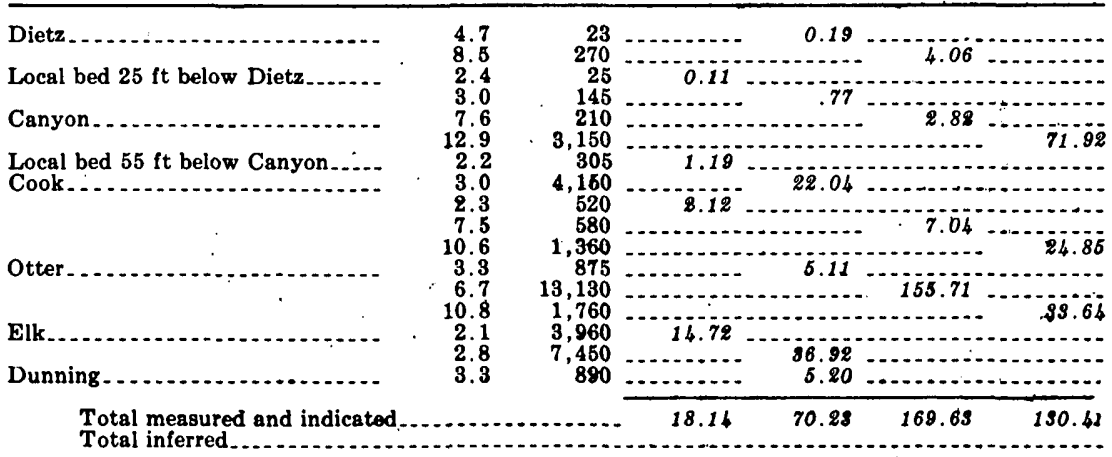

T. 8 S., R. 46 E.

Local bed 135 feet below Roland.

Anderson........

Dietz.

2.4
11.0
8.5

100
2,450
7,960

0.68

8.5 
TABLE 3.-Estimated reserves of coal in the Moorhead coal field, Montana, by township-Continued

\begin{tabular}{|c|c|c|c|c|c|c|}
\hline \multirow[b]{2}{*}{ Bed } & \multirow{2}{*}{$\begin{array}{c}\text { Thickness } \\
\text { (feet) }\end{array}$} & \multirow{2}{*}{$\begin{array}{c}\text { Area } \\
\text { (acres) }\end{array}$} & \multicolumn{4}{|c|}{ Reserves } \\
\hline & & & $\begin{array}{c}\text { Beds } \\
2-2.5 \text { feet } \\
\text { thick }\end{array}$ & $\begin{array}{l}\text { Beds } \\
2.5-5 \text { feet } \\
\text { thick }\end{array}$ & $\begin{array}{c}\text { Beds } \\
5-10 \text { feet } \\
\text { thick }\end{array}$ & $\begin{array}{c}\text { Beds } \\
>10 \text { feet } \\
\text { thick }\end{array}$ \\
\hline
\end{tabular}

T. 8 S., R. 46 E.-Continued

\begin{tabular}{lrrrr}
\hline Local bed 55 ft above Canyon $\ldots$ & 2.2 & 220 & 0.86 &
\end{tabular}

\section{T. 9 S., R. 46 E.}

\section{Arvada}

Roland

Local bed $90 \mathrm{ft}$ below Roland

Local bed $135 \mathrm{ft}$ below Roland....

Smith..

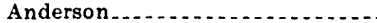

Dietz

Canyon.

Cook

Local.

Total measured and indicated..

Total inferred.

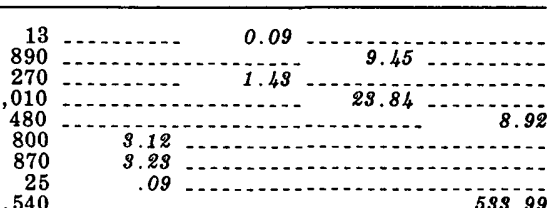

$17,540 \quad 0950.59$

$4,350 \quad 153.99$

3,400
10,130

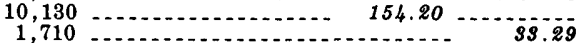

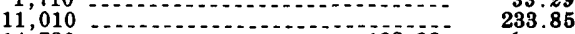

$14,720 \quad \ldots \ldots \ldots$

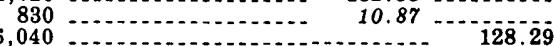

6,040
3,520

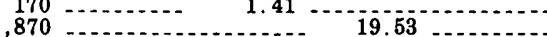

$\begin{array}{lllll}6.44 & 1.52 & 198.36 & 655.89\end{array}$

\section{T. 7 S., R. 47 E.}

Local bed $270 \mathrm{ft}$ above base of Anderson Local bed 210 feet above base of Anderson .................... Anderson:

Upper split.

Middle split

Lower split.

Dietz, upper split

Dietz.

Canyon.

2.9
2.9
3.3
2.3
3.6
8.6
11.0
3.1
3.5
5.4
3.9
6.1
13.0
2.6
6.5
11.4
11.3

Total measured and indicated. Total inferred.

$$
6
$$

0.03

140

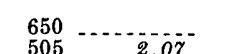

1,290

300

2,460

2,000

15

10,250

1,130

18,010
380

1,200

13,910

9,000

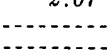

3.80 5.49 12.89

70.76

0

(n) $4.57-47.90$ $4012.20-414.41$

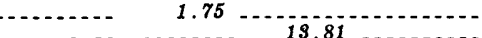

(3) $13.81-280.68$

$\begin{array}{llll}2.07 & 103.66 & 30.72 & 742.99\end{array}$ 180.01 
TABLE 3.-Estimated reserves of coal in the Moorhead coal field, Montana, by township-Continued

\begin{tabular}{|c|c|c|c|c|c|c|}
\hline \multirow[b]{2}{*}{ Bed } & \multirow{2}{*}{$\begin{array}{l}\text { Thickness } \\
\text { (feet) }\end{array}$} & \multirow{2}{*}{$\begin{array}{c}\text { Area } \\
\text { (acres) }\end{array}$} & \multicolumn{4}{|c|}{ Reserves } \\
\hline & & & $\begin{array}{c}\text { Beds } \\
2-2.5 \text { feet } \\
\text { thick }\end{array}$ & $\begin{array}{l}\text { Beds } \\
2.5-5 \text { feet } \\
\text { thick }\end{array}$ & $\begin{array}{c}\text { Beds } \\
\text { 5-10 feet } \\
\text { thick }\end{array}$ & $\begin{array}{c}\text { Beds } \\
>10 \text { feet } \\
\text { thick }\end{array}$ \\
\hline \multicolumn{7}{|c|}{ T. 8 S., R. 47 E. } \\
\hline $\begin{array}{l}\text { Anderson } \\
\text { Dietz }\end{array}$ & $\begin{array}{r}12.0 \\
4.3 \\
7.5 \\
12.1 \\
12.5 \\
15.0\end{array}$ & $\begin{array}{r}8,040 \\
3,060 \\
10,990 \\
1,280 \\
21,130 \\
660\end{array}$ & & 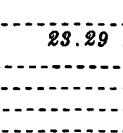 & 145.89 & $\begin{array}{r}170.77 \\
27.41 \\
467.50 \\
17.52\end{array}$ \\
\hline Ottar & $\begin{array}{r}3.2 \\
6.3 \\
12.1 \\
3.0 \\
6.7 \\
12.0\end{array}$ & $\begin{array}{l}2,180 \\
4,730 \\
3,080 \\
1,890 \\
3,070 \\
1,870\end{array}$ & $\begin{array}{ll}-- \\
-- \\
--\end{array}$ & $\begin{array}{l}12.95 \\
10.04 \\
90\end{array}$ & $\begin{array}{r}52.74 \\
36.41\end{array}$ & 95.96 \\
\hline $\begin{array}{l}\text { Otter } \\
\text { Local }\end{array}$ & $\begin{array}{l}4.7 \\
2.6\end{array}$ & 3,200 & (n) & $\begin{array}{r}6.24 \\
14.73 \\
\end{array}$ & . & 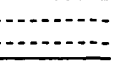 \\
\hline $\begin{array}{l}\text { Total measured and indica } \\
\text { Total inferred....... }\end{array}$ & $\ldots$ & -- & & $\begin{array}{l}50.37 \\
16.28\end{array}$ & $\begin{array}{r}198.68 \\
36.41\end{array}$ & $\begin{array}{r}791.64 \\
57.24\end{array}$ \\
\hline
\end{tabular}

T. 9 S., R. 47 E.

\begin{tabular}{|c|c|c|c|}
\hline $\begin{array}{l}\text { Anderson } \\
\text { Dietz } \\
\text { Canyon } \\
\text { No. } 5 \text {. } 4 \mathrm{a}\end{array}$ & $\begin{array}{r}20.3 \\
2.3 \\
6.3 \\
7.3 \\
13.2 \\
7.3 \\
4.6 \\
6.4 \\
4.7 \\
2.1 \\
3.6 \\
5.9 \\
3.1 \\
5.5 \\
19.3 \\
5.5\end{array}$ & $\begin{array}{r}5,209 \\
3,000 \\
8,230 \\
5,260 \\
11,410 \\
240 \\
8,452 \\
4,690 \\
1,750 \\
640 \\
2,420 \\
2,070 \\
2,390 \\
8,000 \\
670 \\
7,440\end{array}$ & 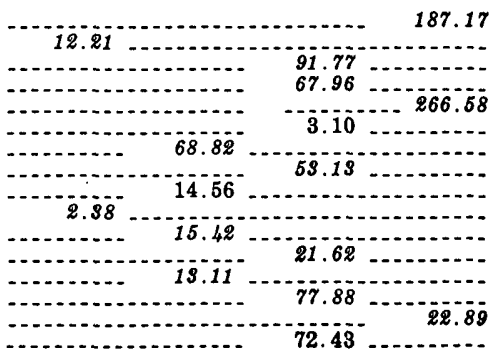 \\
\hline infe & & & $\begin{array}{rr}912.36 & 476.64 \\
75.53 & \end{array}$ \\
\hline
\end{tabular}

\section{T. 7 S., R. 48 E.}

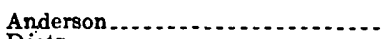

Dietz....

Canyon ...........................

15.0

15.8
15.0

15.0

Cook

3.9

6.9
10.8

No. 5 .

10.8
4.0
5.2

No. 6

4.0

7. $\frac{1}{5}$

No. 6 lower bench............. 2.3

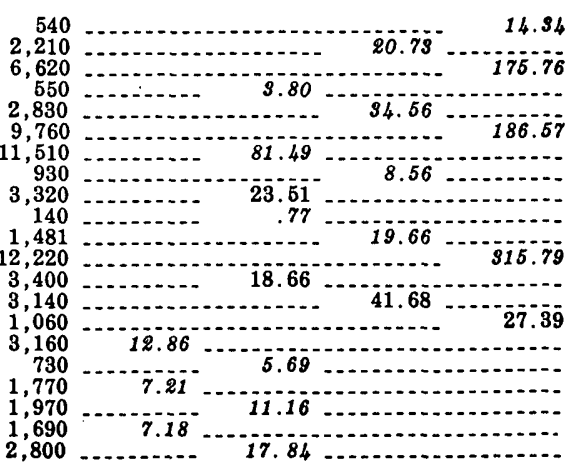


TABLE 3.-Estimated reserves of coal in the Moorhead coal field, Montana, by township-Continued

\begin{tabular}{|c|c|c|c|c|c|c|}
\hline \multirow[b]{2}{*}{ Bed } & \multirow{2}{*}{$\underset{\text { (feet) }}{\text { Thickness }}$} & \multirow{2}{*}{$\begin{array}{c}\text { Area } \\
\text { (acres) }\end{array}$} & \multicolumn{4}{|c|}{ Reserves } \\
\hline & & & $\begin{array}{c}\text { Beds } \\
2-2.5 \text { feet } \\
\text { thick }\end{array}$ & $\begin{array}{l}\text { Beds } \\
2.5-5 \text { feet } \\
\text { thick }\end{array}$ & $\begin{array}{c}\text { Beds } \\
5-10 \text { feet } \\
\text { thick }\end{array}$ & $\begin{array}{c}\text { Beds } \\
>10 \text { feet } \\
\text { thick }\end{array}$ \\
\hline
\end{tabular}

T. 7 S., R. 48 E.-Continued

\begin{tabular}{|c|c|}
\hline No. 8 & 3.8 \\
\hline- & $\begin{array}{l}7.5 \\
3.8 \\
7.5\end{array}$ \\
\hline Cache $(\mathrm{No}, 9) \ldots$ & $\begin{array}{l}2.6 \\
9.4 \\
2.6 \\
9.4\end{array}$ \\
\hline No. 9 lower bench. & $\begin{array}{l}2.3 \\
3.7 \\
2.3 \\
3.7\end{array}$ \\
\hline
\end{tabular}

Total measured and indicated.

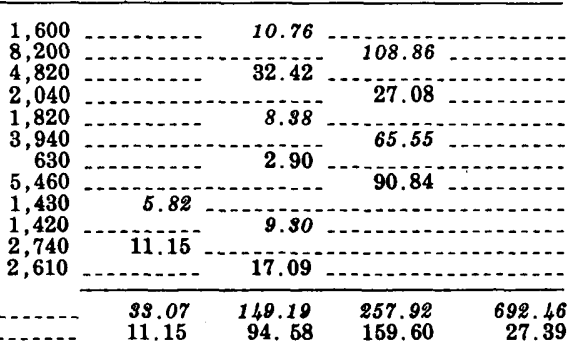

T. 8 S., R. 48 E.

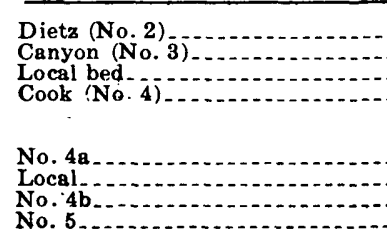

No. 6.

No. 7

No. 8 .

No. $8 \mathbf{a}$

Cache $(\mathrm{No} .9)$

Total measured and indicated

4.7
14.1
5.0
4.7
6.1
12.2
2.6
2.2
2.8
2.2
3.6
6.4
4.0
2.3
3.4
7.6
12.6
3.4
2.3
3.8
2.3
3.5
3.5
3.7
2.3
2.6

Total measured and indicated
Total inferred.

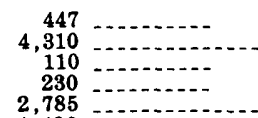

$\begin{array}{r}447 \\ 4,310 \\ 110 \\ 230 \\ 2,785 \\ \hline\end{array}$

3.72

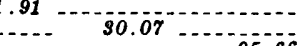
3,235 $3,2350.58 \quad 14.89 \quad \ldots \ldots$ $150 \quad 0.58 \quad \ldots+6.2900$

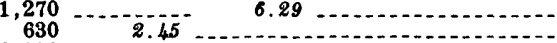

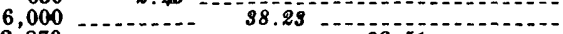
2,870 _. 32.51

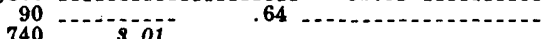

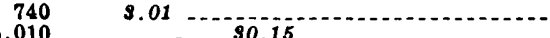
$6,010 \ldots 50.15 \ldots$ 1,950 . $26.29 \quad 210.99$ 1,860 …

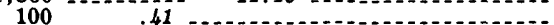
110

$1,100-4,48$

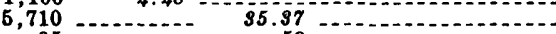
95 .59 $\quad .59$

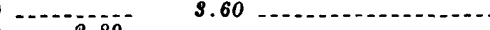
$710 \quad 8.89 \quad 3.50 \quad \ldots$

$\begin{array}{llll}13.82 & 199.87 & 88.81 & 230.21\end{array}$

\section{T. 9 S., R. 48 E.}

Dietz (No. 2)

Canyon (No. 3)

Cook (No. 4).

No. 4 a.

No. $4 b$

No. 5.

No. $5 \mathrm{a}$

15.0
9.8
12.8
2.3
3.7
5.2
2.3
6.0
11.5
2.2
2.9
2.2
3.9
6.7
2.1

Total measured and indicated Total inferred

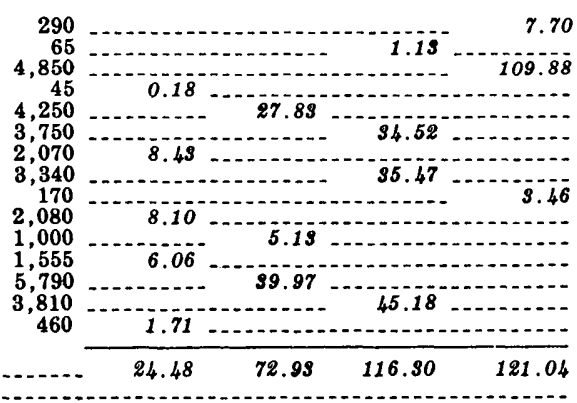


TABLE 3.-Estimated reserves of coal in the Moorhead coal field, Montana, by township-Continued

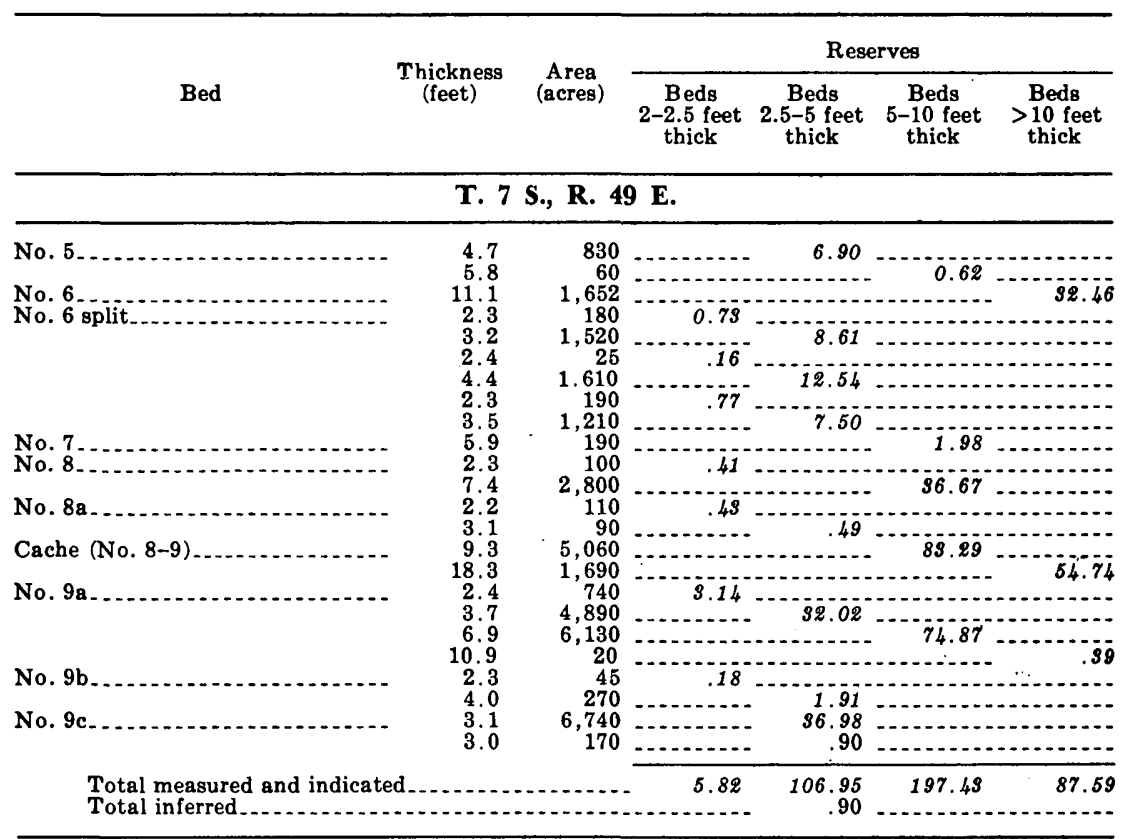

\section{T. 8 S., R. 49 E.}

Dietz (No. 2)

Canyon (No.3)

Cook (No. 4).

No. 5

No.6.

No. 6 split

No. 7.

No. 8

No. $8 \mathrm{a}$

Cache (No. 8-9)

No. $9 \mathrm{a}$

No. $9 \mathrm{c}$

Total measured and indicated. Total inferred

5.0
5.8
12.0
5.0
2.3
4.3
6.2
7.2
3.6
7.4
15.4
3.7
8.2
3.1
2.5
3.9
5.5
2.3
3.4
3.1
2.3
3.0
8.6
2.3
3.0
8.6
2.2
3.4
3.4

$\begin{array}{r}50 \\ 130\end{array}$
290
50


TABLE 3.-Estimated reserves of coal in the Moorhead coal field, Montana, by township—Continued

\begin{tabular}{|c|c|c|c|c|c|c|}
\hline \multirow[b]{2}{*}{ Bed } & \multirow{2}{*}{$\begin{array}{c}\text { Thickness } \\
\text { (feet) }\end{array}$} & \multirow{2}{*}{$\begin{array}{c}\text { Area } \\
\text { (acres) }\end{array}$} & \multicolumn{4}{|c|}{ Reserves } \\
\hline & & & $\begin{array}{c}\text { Beds } \\
2-2.5 \text { feet } \\
\text { thick }\end{array}$ & $\begin{array}{l}\text { Beds } \\
2.5-5 \text { feet } \\
\text { thick }\end{array}$ & $\begin{array}{c}\text { Beds } \\
5-10 \text { feet } \\
\text { thick }\end{array}$ & $\begin{array}{l}\text { Beds } \\
>10 \text { feet } \\
\text { thick }\end{array}$ \\
\hline
\end{tabular}

\section{T. 9 S., R. 49 E.}

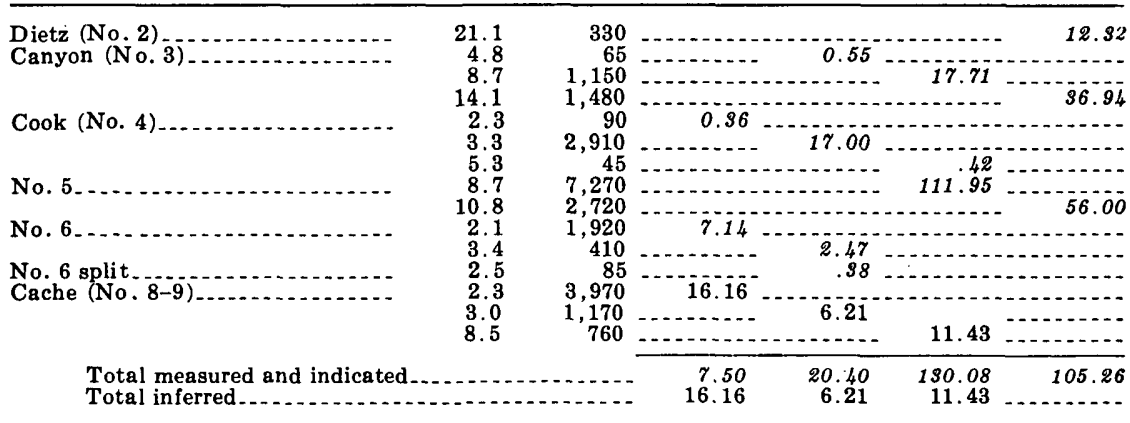

T. 6 S., R. 50 E.

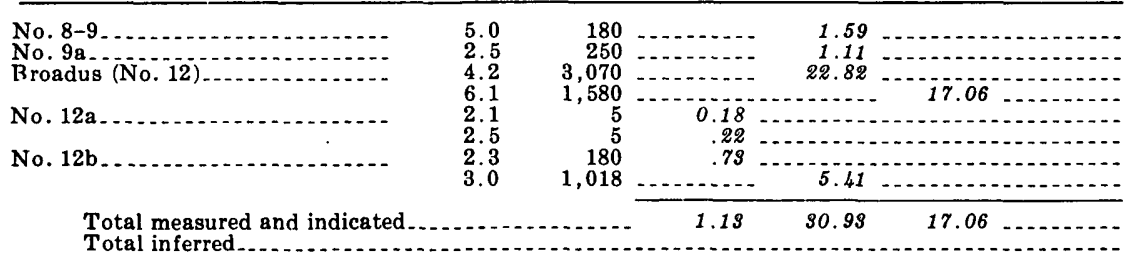

Total measured and indicated

\section{T. 7 S., R. 50 E.}

Cook (No. 4)

No. 5 .

No. 6 .

No. $8-9$

12.0
12.3
7.8
17.8
2.3
3.6
6.0
2.3
3.6
2.3
4.0
2.3
3.4
3.4
3.4
3.4

Total measured and indicated

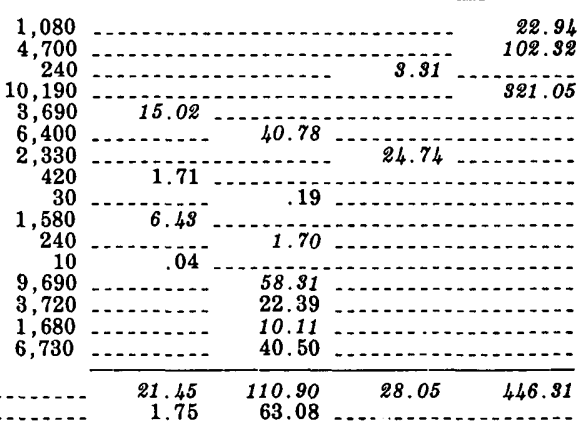

Total inferred

1.75

63.08

\section{T. 8 S., R. 50 E.}

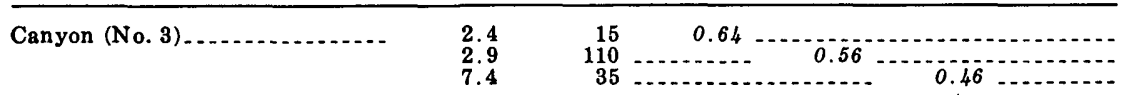


TABLE 3.-Estimated reserves of coal in the Moorhead coal field, Montana, by township-Continued

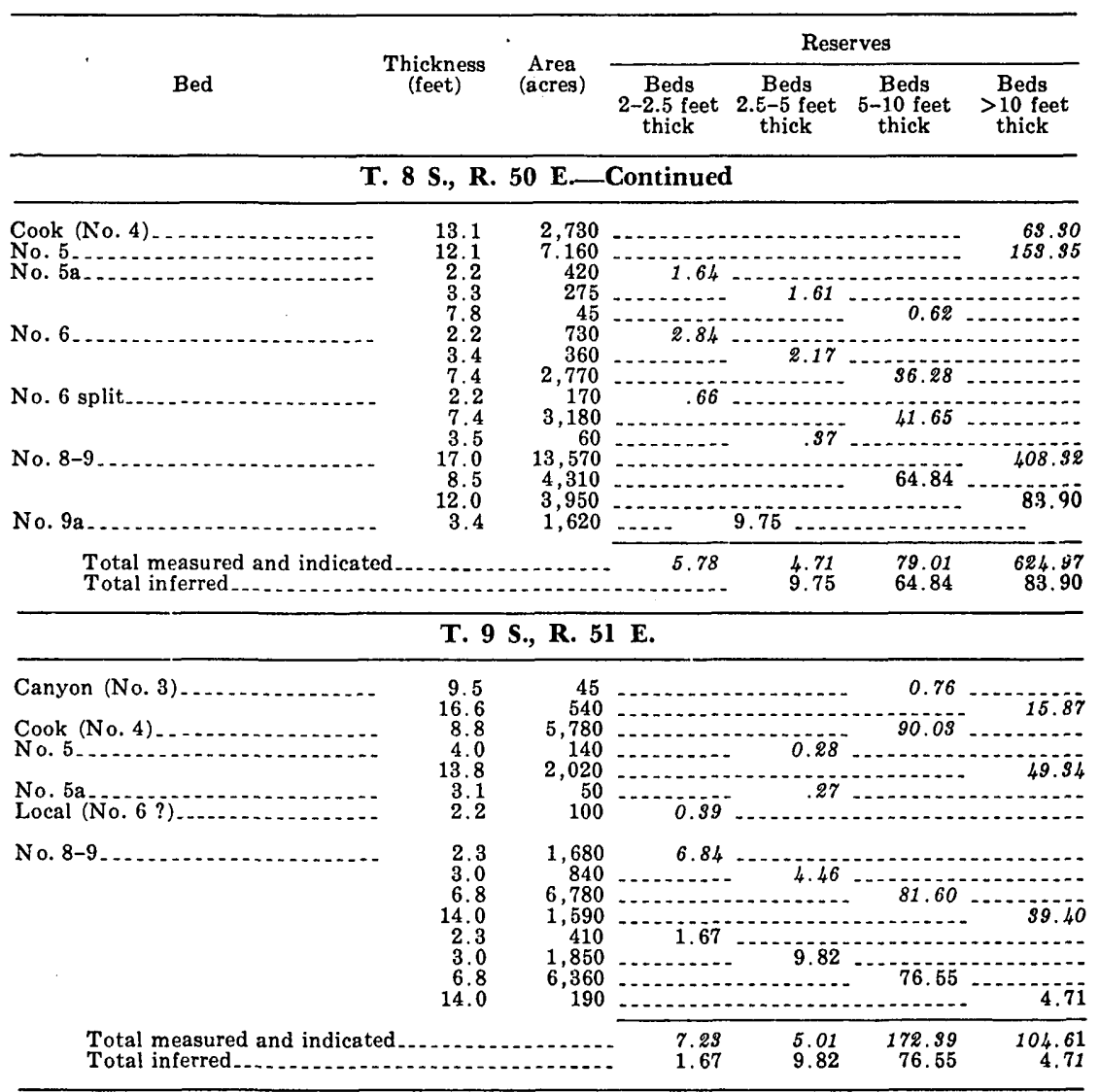

T. 6 S., R. 51 E.

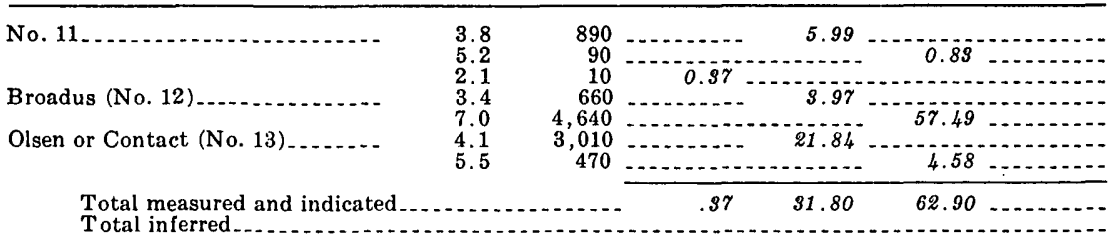

T. 7 S., R. 51 E.

\begin{tabular}{|c|c|c|c|c|}
\hline 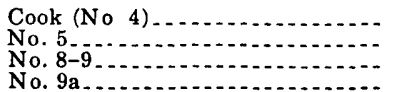 & $\begin{array}{r}11.1 \\
12.0 \\
23.9 \\
2.3\end{array}$ & $\begin{array}{r}330 \\
2,740 \\
6,570 \\
730\end{array}$ & 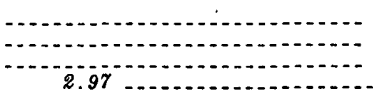 & $\begin{array}{r}6.48 \\
58.20 \\
277.93\end{array}$ \\
\hline
\end{tabular}


TABLE 3.-Estimated reserves of coal in the Moorhead coal field, Montana, by township-Continued

\begin{tabular}{|c|c|c|c|c|c|c|}
\hline \multirow[b]{2}{*}{ Bed } & \multirow{2}{*}{$\underset{\text { (feet) }}{\text { Thickness }}$} & \multirow{2}{*}{$\underset{\text { (acres) }}{\text { Area }}$} & \multicolumn{4}{|c|}{ Reserves } \\
\hline & & & $\begin{array}{c}\text { Beds } \\
2-2.5 \text { feet } \\
\text { thick }\end{array}$ & $\begin{array}{l}\text { Bers } \\
2.5-5 \text { feet } \\
\text { thick }\end{array}$ & $\begin{array}{c}\text { Beds } \\
5-10 \text { feet } \\
\text { thick }\end{array}$ & $\begin{array}{c}\text { Beds } \\
>10 \text { feet } \\
\text { thick }\end{array}$ \\
\hline \multicolumn{7}{|c|}{ T. 7 S., R. 51 E.Continued } \\
\hline No. $11 \ldots$ & $\begin{array}{l}3.6 \\
4.7 \\
5.8 \\
2.9\end{array}$ & $\begin{array}{r}1,310 \\
1,800 \\
90 \\
110\end{array}$ & - & $\begin{array}{r}8.95 \\
14.97 \\
.56\end{array}$ & 0.92 & \\
\hline Broadus (No. 12) ........ & $\begin{array}{l}2.3 \\
3.4 \\
7.0\end{array}$ & $\begin{array}{r}600 \\
6,520 \\
270\end{array}$ & 2.44 & 39.24 & 3.95 & \\
\hline Olsen or Contact (No. 13) $\ldots \ldots$ & $\begin{array}{l}3.4 \\
3.9\end{array}$ & $\begin{array}{r}9,130 \\
760\end{array}$ & (2) & $\begin{array}{r}54.94 \\
5.25\end{array}$ & - & \\
\hline $\begin{array}{l}\text { Total measured and indicated } \\
\text { Total inferred........... }\end{array}$ & d........ & $\ldots$ & 5.41 & $\begin{array}{l}67.81 \\
55.50\end{array}$ & 4.27 & 342.61 \\
\hline
\end{tabular}

\section{T. 8 S., R. 51 E.}

Cook (No. 4) ........ 12.0

No. 5 (No. 4)

No. $8 \mathrm{a}-9$

13.0
6.6

No. $9 \mathrm{a}$

No. 11 .

Broadus (No. 12)

Olsen or Contact (No. 13)

110
200
370
5,940
1,110
1,400
830
6,430
1,930
490
370
7,360

110
200
370
, 940
, 110
, 400
830
430
930
490
370
, 360

Total measured and indicated
Total inferred.

22.3

2.3

2.9

3.6

5. 5

2.3

4.2

7,360

2.94

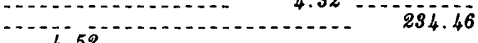

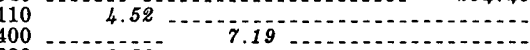

3.98
40.97

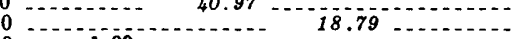

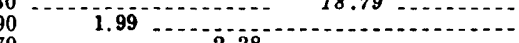

2.38
24.71

T. 9 S., R. 51 E.

\begin{tabular}{|c|c|c|c|}
\hline $\begin{array}{l}\text { No. } 5 \\
\text { Local } 8.9 \\
\text { Local } 8 \text {. } \\
\text { Olsen or Contact }(\mathrm{No} .13)\end{array}$ & $\begin{array}{r}2.4 \\
2.6 \\
14.4 \\
2.2 \\
6.8 \\
14.0 \\
3.2 \\
2.5 \\
4.3\end{array}$ & $\begin{array}{r}15 \\
90 \\
110 \\
80 \\
1,170 \\
1,210 \\
35 \\
880 \\
45\end{array}$ & 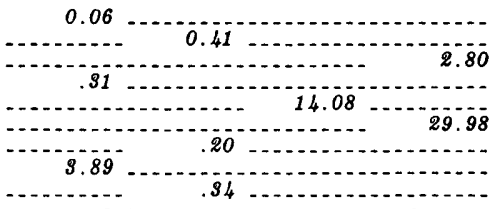 \\
\hline ured and indicate & & $\cdots$ & 14.08 \\
\hline
\end{tabular}

T. 4 S., R. 52 E.

\begin{tabular}{|c|c|c|c|c|}
\hline 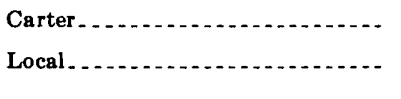 & $\begin{array}{l}2.3 \\
3.1 \\
2.4 \\
2.1\end{array}$ & $\begin{array}{r}\mathbf{3 3 0} \\
\mathbf{2 5} \\
\mathbf{3 0} \\
\mathbf{3 0}\end{array}$ & $\begin{array}{r}1.34 \\
.13 \\
.11\end{array}$ & $\begin{array}{r}0.14 \\
0\end{array}$ \\
\hline $\begin{array}{l}\text { Total measured and indicated } \\
\text { Total inferred }\end{array}$ & 8 & 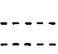 & $\begin{array}{c}1.58 \\
-.-2 .-\end{array}$ & 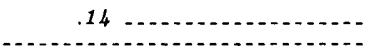 \\
\hline
\end{tabular}

T. 5 S., R. 52 E.

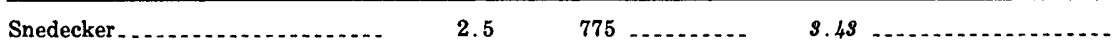


TABLE 3.-Estimated reserves of coal in the Moorhead coal field, Montana, by township-Continued

\begin{tabular}{|c|c|c|c|c|c|c|}
\hline \multirow[b]{2}{*}{ Bed } & \multirow{2}{*}{$\underset{\text { (feet) }}{\text { Thickness }}$} & \multirow{2}{*}{$\begin{array}{c}\text { Area } \\
\text { (acres) }\end{array}$} & \multicolumn{4}{|c|}{ Reserves } \\
\hline & & & $\begin{array}{c}\text { Beds } \\
2-2.5 \text { feet } \\
\text { thick }\end{array}$ & $\begin{array}{c}\text { Beds } \\
2.5-5 \text { feet } \\
\text { thick }\end{array}$ & $\begin{array}{c}\text { Beds } \\
5-10 \text { feet } \\
\text { thick }\end{array}$ & $\begin{aligned} & \text { Beds } \\
&> 10 \text { feet } \\
& \text { thick }\end{aligned}$ \\
\hline
\end{tabular}

T. 6 S., R. 52 E.

\begin{tabular}{ccccc}
\hline Snedecker...... 3.6 & 3,960 & & \\
\hline & T. 8 S., R. 52 E.
\end{tabular}

Local ......................... 3

T. 9 S., R. 52 E.

Local.

3.5

280

1.73

A summary of estimated reserves by townships is given in table 4.

\section{ADDITIONAL POSSIBLE RESERVES}

A sequence of rocks several hundred feet thick is present in the lower part of the Tongue River Member in many townships below the coal beds that are included in the table of reserves. Regional data indicate that this lower part of the member contains many coal beds and that its maximum depth in the coal field is less than 2,000 feet. A conservative estimate of possible coal reserves in the buried part of the Tongue River Member in the mapped area indicates a total of 30 billion tons. If this amount is added to the total reserve shown in table 4 , the total is $511 / 2$ billion tons, which is 23 percent of the total estimated coal reserves of Montana (Combo and others, 1949, p. 21).

\section{DESCRIPTIONS BY TOWNSHIP}

T. 7 S., R. 43 E.

(pl. 3)

The surface of T. 7 S., R. 43 E., is relatively rugged, although the valley of Lee Creek is wide and its slopes are somewhat subdued. Stroud Creek and Hay Canyon have relatively narrow steep-sided valleys, and the valley of Hanging Woman Creek at the west margin of the area is relatively wide. Much of the surface of the township is clinker that marks the position of the thick Anderson coal bed. The clinker margins and the northfacing slopes are forested with pines, but the timber stand is not dense. 


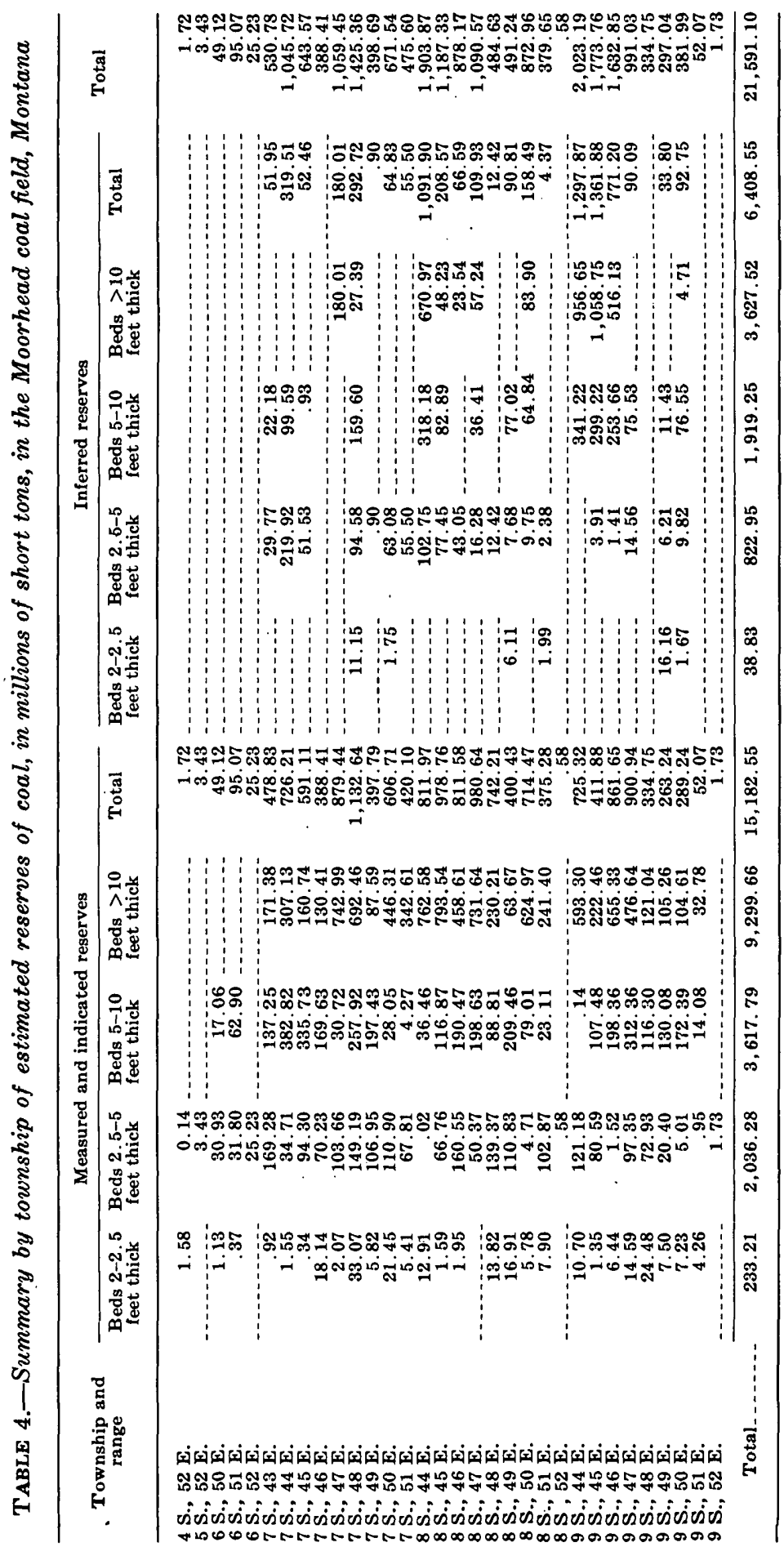


The exposed rocks consists of about 800 feet of interbedded light-yellow-gray sandstone, shale, and coal beds of the upper part of the Tongue River Member of the Fort Union Formation. It is estimated that an additional 500 feet of the Tongue River Member lies beneath the surface. The uppermost 200 feet or more of the member has been removed by erosion.

The rocks in the area between Stroud Creek and Hay Canyon appear to dip southward at less than $2^{\circ}$. Elsewhere, the dip of the rocks is difficult to determine. The subsurface data suggest a southward dip of about 50 feet per mile in the north half of the township and 30 feet per mile in the south half.

Smith coal bed.-The uppermost coal bed is the Smith bed, which is about 125 feet above the base of the clinker formed by the Anderson bed and which crops out at several places near the crest of the ridge in secs. 25 and 26 . The bed has a thickness of 3 feet 2 inches, which includes a shale parting 1 inch thick near the base at locality 82 in sec. 25 . The average thickness was estimated to be 3 feet in 200 acres (table 3 ). The thickness of the bed diminishes rapidly westward from this locality to slightly less than 2 feet in sec. 26. Many silicified tree stumps occur in the coal bed.

Anderson coal bed.-Although the Anderson coal bed does not crop out in this township, a widespread thick clinker at this horizon indicates the former existence of a thick coal bed. The unbaked condition of the rocks in parts of secs. 25, 26, 35, and 36 indicates that a part of the Anderson bed remains unburned here; the total area was estimated to be 850 acres and the thickness of the coal bed to be 20 feet (table 3 ).

Dietz coal bed.-The Dietz coal bed, which is about 55 feet below the Anderson bed, ranges in thickness from 5 feet 5 inches to 12 feet 6 inches at four localities in the south half of the township where it was measured. In the north half of the township, it was measured only at locality 14 near the NW. cor. sec. 2; here it is 5 feet 3 inches thick and includes a parting of shale 8 inches thick.

Local coal beds.-A local coal bed that lies 60 feet above the Canyon bed ranges in thickness from 2 feet 4 inches to 7 feet 2 inches at localities where it was measured on Lee and Hanging Woman Creeks in the northern and northwestern parts of the township. The coal bed is variable in quality as well as in thickness; it contains partings of shale at some places. A local bed 
20 feet higher, or 80 feet above the Canyon bed, was mapped chiefly in secs. 16 and 17. It is 5 feet 2 inches thick at locality 63 in the NE1/4 sec. 17 and 2 feet 4 inches thick at locality 66 in the SE1/4 sec. 17.

Canyon (No. 3) coal bed.-The Canyon coal bed, which is about 170 feet below the Dietz bed, crops out extensively along Lee and Hanging Woman Creeks but is variable in thickness and quality. Locally it grades into carbonaceous shale. Moreover, some doubt exists as to the identification of the coal bed in parts of the area.

Local coal bed.-A bed of coal 55 feet below the Canyon coal, containing 3 feet 4 inches of weathered coal, crops out at locality 85 in the SE $1 / 4$ sec. 12 . It was mapped across sec. 12 but was not recognized elsewhere.

Cook (No. 4) coal bed.-A coal bed, believed to be equivalent to the Cook coal bed of the Birney-Broadus coal field adjacent to the mapped area on the north, is 130 feet below the Canyon bed. It crops out extensively and was measured at many localities. Its thickness ranges from 2 feet to 12 feet 8 inches where it was measured.

Local coal bed.-A coal bed about 20 feet below the Cook coal ranges from 3 feet 4 inches to 3 feet 9 inches at localities 18 and 21 in sec. 4.

Otter coal bed.-The Otter coal bed, lying 50 feet below the Cook bed, occurs in a sequence of carbonaceous shale near the mouth of Lee Creek and along Hanging Woman Creek in secs. 3, 4, 8, 9, 10, 16, and 17. Farther south and east the coal bed appears to grade into carbonaceous shale. Its thickness, where measured, ranged from 2 feet 8 inches to 5 feet 6 inches.

Local coal bed.-A local coal bed 50 feet above the Wall bed crops out extensively in the north-central and southwestern parts of the township. Its thickness ranges from 2 feet 1 inch to 13 feet 6 inches at the 16 localities where ii was measured. It appears to thicken southward across the township. The bed measured at locality 71 in the $\mathrm{N} 1 / 2$ sec. 20 is a lower bench of the local bed.

Wall coal bed.-The Wall coal bed 280 feet below the Canyon bed crops out extensively in the northwestern part of the township. It ranges from 2 feet to 5 feet 11 inches thick and contains partings of shale.

Pawnee (No. 6) coal bed.-A thin coal bed 45 feet below the Wall bed and tentatively correlated with the Pawnee coal bed of the adjacent coal field to the north was mapped in secs. 4 and 5 
in Lee Creek valley. It is 2 feet thick at locality 32 in the NW $1 / 4, S^{1} 1 / 4$ sec. 4.

Local coal bed.-A coal bed about 80 feet below the Pawnee coal bed is 3 feet 9 inches thick at locality 33 in the $\mathrm{N} 1 / 2$ sec. 5 .

$$
\text { T. } 7 \text { S., R. } 44 \text { E. }
$$

The clinker of the Anderson coal bed dominates the surface of T. 7 S., R. 44 E. Most of the township is drained by the south, middle, and north forks of Lee Creek. These intermittent streams have cut relatively deep steep-sided valleys through the Anderson clinker and the thick sandstone underlying it. The valleys widen perceptibly below the outcrop of the Deitz clinker because a sequence of soft shales is predominant below the Dietz bed. The broad divide above the Anderson clinker in the eastern part of the township is a rolling grassy upland. Pine trees grow on the edges of the clinker, which borders the valleys, and on the northfacing slopes. There are patches of bare rocks on the southfacing slopes. The maximum relief in the township is about $\mathbf{5 5 0}$ feet.

The exposed rocks consist of about 550 feet of interbedded lightyellow-gray sandstone, shale, and coal of the upper part of the Tongue River Member of the Fort Union Formation. An estimated additional 950 feet of the Tongue River Member lies beneath the surface. Locally, only the uppermost 150 feet or less has been removed by erosion. Mesas along the divide, particularly in secs. 1, 2, and 4, consist of strata that may be uppermost Tongue River and may possibly include the basal part of the Wasatch Formation. The natural burning of the Anderson coal bed has produced an extensive thick clinker in many parts of the township. Thinner clinkers are present at the horizons of the Dietz and Canyon coal beds. The rocks dip southwestward at about 50 feet per mile, according to data obtained from logs of wells drilled in the region for oil and gas.

Four to five coal beds, ranging in thickness from a few inches to about 2 feet and each containing many silicified tree stumps and logs, occur in the 100 - to 200 -foot interval that is directly above the Anderson coal bed. In the northern part of the township, at least one of these beds is locally 2 feet or more thick. Specific correlations, however, with the coal beds, including the Smith bed, in the area south of this township could not be made with confidence. 
Local coal beds.-A thin coal bed, lying an unknown distance above the Smith bed, crops out near the crest of a ridge at the northern edge of the township and is the highest bed in the township. Its thickness is 2 feet 5 inches at an unrecorded locality a few hundred feet east of this township. A coal bed about 50 feet above the Smith bed has thicknesses of 2 feet 11 inches and 3 feet 10 inches, respectively, at localities 87 and 86 in sec. 4. A coal bed about 28 feet above the Smith bed has thicknesses of from $21 / 2$ to $3 \frac{1}{2}$ feet in secs. 2 and 3 . It is 3 feet 5 inches thick at locality 88 in the NW1/4 sec. 2 . Silicified tree stumps are common in this bed.

Smith bed.-The Smith coal bed, which is about 125 feet above the base of the clinker of the Anderson bed, is less than 4 feet thick, including a thin parting near its base, at localities 93 and 94 in sec. 31. It maintains a thickness of more than 2 feet southward into T. 8 S., R. 44 E., but thins eastward to less than 2 feet in sec. 32. Elsewhere along the divide, in secs. 35 and 26 , the bed is less than 2 feet thick. Many silicified tree stumps are present.

Anderson coal bed.-The Anderson coal bed does not crop out in this township. A thick clinker at this horizon, however, is widespread and gives evidence of a former thick coal bed. The Anderson bed contains about 15 feet of coal in nearby townships. The unbaked condition of the rocks in several tracts where the coal is under a cover of less than 200 feet indicates that here the Anderson bed remains unburned.

Dietz (No. 2) coal bed.-The Dietz coal bed, which is about 65 feet below the Anderson bed, has burned at the outcrop nearly everywhere in the township. Only one measurement was obtaind. The coal is 8 feet 6 inches thick at locality 92 in sec. 30 . The bed has an average thickness of nearly 8 feet in adjacent townships to the east, southeast, and south.

Canyon (No. 3) coal bed.-The Canyon coal bed, which is about 145 feet, below the Dietz bed, crops out in this township only in the west-central part, in the valley of Lee Creek. Its position commonly is marked by a conspicuous band of clinker. The bed is more than 9 feet thick at locality 89 in sec. 8 . It has an average thickness of nearly 8 feet in the western part of T. 7 S., R. 45 E., that is adjacent on the east and is known to maintain a rather uniform thickness in the region. It is probable, therefore, that the Canyon bed is a thick bed of coal under most of the township. 
Cook (No. 4) coal bed.-A coal bed, which is correlated with the Cook bed of the adjacent Birney-Broadus coal field to the north, is about 150 feet below the Canyon bed. It crops out in the valley of Lee Creek in sec. 18. The bed is 15 feet 3 inches thick at locality 90 in the NW1/4 sec. 18 and more than 9 feet thick at locality 91 in the SE $1 / 4$ sec. 18 . The thickness of this bed is variable in adjacent townships; therefore, it is not possible to predict its thickness far from the area of outcrop on Lee Creek. Reserves of coal in the Otter bed and a local bed 50 feet above the Wall bed, based on data from the adjacent area, are shown in table 3. Other coal beds may reasonably be expected in the part of the Tongue River Member that lies at shallow depth in this township.

\section{T. 8 S., R. 44 E. \\ (pl. 4)}

Rolling grass-covered upland characterizes T. 8 S., R. 44 E. Units of brown sandstone each 3 feet to at least 10 feet thick that lie below the Roland coal bed form benches that support sparse growths of pine trees on some of the outcrops. Parts of the upland are dry-farmed for small grains, including barley and oats. Clinker is present only in the northeastern part of the area and in secs. 6 and 7 where the thick clinker of the Anderson coal bed is at the surface. It forms red hummocks in the grassy plain in much of this area.

The exposed rocks consist of about 600 feet of interbedded lightyellow-gray sandstone, shale, and coal beds. Of these rocks, the uppermost 75 feet is included in the Wasatch Formation because it lies above the Roland coal bed, which has been considered to be the uppermost bed of the Tongue River Member of the Fort Union Formation. The remaining 525 feet is included in the Tongue River Member. An additional 900 feet of the Tongue River Member is estimated to lie beneath the surface.

The rocks dip slightly west of south at about 55 feet per mile, as determined from the logs of wells drilled for oil and gas. A small normal fault that has a measured throw of about 15 feet down on the south trends east-northeastward in the SE1/4, sec 22.

Arvada coal bed.-The Arvada coal bed, which is about 75 feet above the Roland bed, crops out in sec. 27. It is 3 feet 8 inches thick at locality 106. The bed is thin and underlies only a small area and so does not contain important reserves of coal. 
Roland coal bed.-The Roland coal bed crops out in many places along the Bear Creek-Hanging Woman Creek divide in the south half of the township. Its thickness ranges from more than 6 feet at locality 107 in the SW1/4 sec. 27 to 8 feet 10 inches at locality 105 in the SW $1 / 4$. sec. 26. The bed contains silicified tree stumps at some localities.

Local coal bed.-A thin coal bed, about 60 feet below the Roland bed, underlies a large area in the southern part of the township. Sections of the bed measured at many places, however, showed the thickness of the coal to be less than 2 feet.

Smith coal bed.-The Smith coal bed, which is about 180 feet below the Roland bed, crops out at many places in the township. Its thickness is slightly more than 2 feet at the six localities where measured sections are shown; elsewhere in the township the thickness of the coal is less than 2 feet. The coal bed contains silicified tree stumps.

Anderson (No. 1) coal bed.-The Anderson coal bed about 300 feet below the Roland bed, is not exposed in this township, but a thick clinker at its horizon is present in the northeastern and northwestern parts of the township. The coal bed is thick in adjacent townships to the west, east, and south, and therefore may be about 20 feet thick in this township.

Dietz (No. 2) coal bed.-The Dietz coal bed, about 60 feet below the Anderson bed, crops out only along Little Bear Creek in secs. 1,2 , and 12. The coal is more than 8 feet thick at locality 97 in sec. 2 , and sections measured in adjacent townships suggest that the coal may be about 12 feet thick in much of this township.

Reserves of coal were calculated (table 3 ) for the Canyon, Cook, Otter, and a local bed on the basis of data in adjacent townships.

$$
\begin{gathered}
\text { T. } 9 \text { S., R. } 44 \text { E. } \\
\text { (pl. } 4 \text { ) }
\end{gathered}
$$

Trail Creek and its tributaries and the east fork of Trail Creek drain T. 9 S., R. 44 E., and after combining in the township adjacent to the west, flow northwestward into Hanging Woman Creek. All the streams are intermittent. The main valleys are broad and comparatively straight. The slopes are moderately dissected, and the interstream areas have low relief. Most of the township is a rolling grass-covered upland, but this upland is much more dissected than that of the adjacent township to the north. The valley slopes are fairly steep and are characterized 
by several small ledges of brown sandstone. Pine trees grow sparsely on some of the sandstone.

The exposed rocks consist of about 600 feet of interbedded lightyellow-gray to brown sandstone, gray shale, and coal beds. Beds of gray shale predominate in this township. Of these rocks, the uppermost 250 feet is included in the Wasatch Formation because it lies above the Roland coal bed, which is considered to be the uppermost bed of the underlying Tongue River Member of the Fort Union Formation. The Wasatch Formation here consists predominantly of gray shale. Several units of brown sandstone, some of which are fossiliferous, are present. The remaining 350 feet of the exposed rocks is included in the Tongue River Member. It is estimated that an additional 1,100 feet of the member lies beneath the surface. The local warping and faulting of generally drab coal-bearing strata add to the uncertainties of the correlation of individual coal beds in this township.

Four normal faults, whose displacements are 50-200 feet down on the south, trend eastward to northeastward. Two short normal faults trend northeastward; the maximum displacement here is about 50 feet down on the northwest. Data obtained from logs of deep wells drilled for oil and gas in this township and in the adjacent townships to the east and west show that the rocks dip southwestward about 50 feet per mile.

Felix coal bed.-A coal bed about 250 feet above the Roland bed, which is tentatively correlated with the Felix coal bed of the adjacent Spotted Horse coal field to the south, is the highest coal bed in the township. It is present in a very small area near the SW. cor. sec. 32 . The main bench of coal is 5 feet 5 inches thick, and an upper bench 9 feet higher is 2 feet 1 inch thick, including a shale parting 4 inches thick, at locality 149 in the SW $1 / 4$ sec. 32 .

Arvada(?) coal bed.-A coal bed about 2-5 feet thick lying about 100 feet above the Roland coal in secs. 24 and 30-33 is tentatively correlated with the Arvada coal bed. It was measured at six localities in secs. 24, 31, and 32 .

Local coal bed.-A coal bed 60 feet above the Roland is present locally in the southern part of the township. It is 3 feet 9 inches thick at locality 156 south of the center of sec. 34 .

Roland coal bed.-The Roland coal bed crops out in many parts of the township. The bed was measured at 13 localities. It is split into several benches by two or more thick shale partings at many places. 
Local coal bed.-A local coal bed about 35 feet below the Roland bed is exposed in a small area along the divided between Trail Creek and the east fork of Trail Creek near the center of the township. The coal is 2 feet 2 inches thick at locality 131 in the NW $1 / 2$ sec. 22.

Local coal bed.-A local coal bed about 80 feet below the Roland bed is persistent in the township but is less than 2 feet thick at most places. Its thickness ranges from 2 feet 7 inches to 4 feet 9 inches at the four localities in secs. $19,32,33$, and 35 where it was measured. The coal bed is split into two benches by a shale parting at each locality.

Local coal bed.-A local coal bed about 135 feet below the Roland bed has a nearly uniform thickness, averaging about $31 / 2$ feet, throughout much of the township. Its thickness was measured at 20 localities. The coal bed commonly contains silicified tree stumps.

Smith coal bed.-The Smith coal bed, which is about 205 feet below the Roland bed, is exposed along the east fork of Trail Creek and along Trail Creek, but the coal is less than 2 feet thick at most places. A slighlty thicker Smith bed is present at the six localities where it was measured. It commonly contains silicified tree stumps.

Anderson (No. 1) coal bed.-The Anderson coal bed, which is about 330 feet below the Roland bed, is probably present throughout the township. The top 7 feet of the bed is exposed in the creek bottom at locality 109 in the $\mathrm{SW} 1 \frac{1}{4} \mathrm{SE} 1 / 4, \mathrm{sec}$. 5. The basal 16 feet 6 inches of the bed is exposed at locality 144 in the $\mathrm{SE}_{1} 1 / 4 \mathrm{NE} 1 / 4$ sec. 29 , and the upper part has been eroded there. It is likely that a thick Anderson coal bed is available for strip mining at shallow depths along the valley of Trail Creek and along the east fork of Trail Creek.

Dietz (No. 2) and Canyon (No. 3) coal beds.-The Dietz and Canyon coal beds almost surely are present at shallow depth in much of the township, according to data on these beds in adjacent areas to this township.

$$
\begin{aligned}
& \text { T. } 7 \text { S., R. } 45 \text { E. } \\
& \text { (pl. 4) }
\end{aligned}
$$

Otter Creek flows northward near the eastern margin of T. $7 \mathrm{~S}$, R. $45 \mathrm{E}$. Its tributaries in this township are Horse, Camp, and Bear Creeks; Cub, Tooley, and Little Bear Creeks are tributaries of Bear Creek. All streams, including Otter Creek, are inter- 
mittent. The valley bottoms of Otter and Bear Creeks are broad and open. The topography of the rest of the township is rugged: valley sides are steep and deeply dissected, and sparsely timbered slopes rise as much as 550 feet from the floors of the valleys to the edge of the clinker-capped ridges. The maximum relief is about 800 feet.

The exposed rocks consist of about 800 feet of interbedded light-yellow-gray sandstone, shale, and coal beds of the upper part of the Tongue River Member of the Fort Union Formation. It is estimated that an additional 500 feet of the member lies beneath the surface. The uppermost 150 feet of the Tongue River Member has been removed by erosion. Red bands of clinker are conspicuous. Data obtained from logs of wells drilled for oil and gas show that the rocks dip southwestward about 60 feet per mile.

Local coal bed.-A thin lenticular bed of coal occurs in the midst of a zone about 50 feet thick that contains many beds of carbonaceous shale about 165 feet above the Anderson coal bed. Its stratigraphic position suggests that it is 28 feet above the Smith coal bed. Silicified tree stumps are present in the coal bed and in the associated carbonaceous shale beds. Its thickness may reach 2 feet 6 inches in only a small area in the northwesternmost part of sec. 6 .

Anderson (No. 1) coal bed.-The Anderson coal bed does not crop out in this township, but a thick widespread clinker at the horizon of the Anderson indicates the former existence of a thick coal bed. The Anderson bed contains about 15 feet of coal in adjacent townships. The unbaked condition of the rocks indicates that the Anderson coal bed remains unburned in a small area in secs. 6, 7, 17, and 18 under a cover not more than 200 feet thick.

Dietz (No. 2) coal bed.-The Dietz coal bed, which lies about 50 feet below the Anderson bed, was mapped throughout most of the township, but measurements of its thickness were made only in the south half. The thickness in the seven localities where it was measured ranges from 2 feet 8 inches to 11 feet 4 inches; the thickest section includes a shale parting 10 inches thick near the middle of the bed and a bed of shaly coal 1 foot thick at the base.

Canyon (No. 3) coal bed.-A thick clinker 155 feet below the Dietz bed throughout the township marks the position of the Canyon coal bed. The true thickness of the coal bed is believed to be much greater than is indicated by the sections measured at 
three localities in the south half of the township. The thickness shown at these three localities ranges from 4 feet to 7 feet 6 inches. Sections of the bed measured in adjacent townships show its thickness to range from 9 to 25 feet and, except for the southern part, similar thicknesses can be expected in this township.

Cook (No. 4) coal bed.-A coal bed tentatively correlated with the Cook bed crops out locally in secs. 23 and 24 . Its thickness ranges from 2 feet 6 inches to 3 feet 10 inches. The coal is shaly at locality 236 in the SE1/4 sec. 23.

Otter coal bed.-The Otter coal bed, which here lies about 165 feet below the Canyon bed, crops out extensively along the valleys in the eastern part of the township. This bed may be equivalent to the Wall coal bed in the adjacent Birney-Broadus coal field to the north (Warren, 1959, p. 573). The seven sections measured show a wide range in thickness of the coal; it ranges from 2 feet 8 inches at locality 228 in the SW1/4 sec. 27 to 20 feet 8 inches, including a shale parting 3 feet 2 inches thick, at locality 234 in the $\mathrm{N} 1 / 2$ sec. 23.

Local coal bed.-A local coal bed about 30 feet below the Otter bed crops out for a short distance on Camp Creek in secs. 3 and 10 and on Horse Creek in the NE1/4 sec 1 . It is 2 feet 4 inches thick at locality 245 near the SE. cor. sec. 3 and 4 feet thick but weathered at locality 250 in the $N E 1 / 4$ sec. 1.

Elk coal bed.-A coal bed or beds (the coal occurs in two benches or beds at several places) at about the stratigraphic position of the Wall and the Elk coal beds crop out extensively along Otter Creek valley in the eastern part of the township. The coal thickness was measured at nine localities where the thickness of the main bench ranges from 2 feet 2 inches to 5 feet 6 inches.

Outcrops of thick beds of coal in adjacent townships indicates that coal beds may be present in this township in the lower part of the Tongue River Member at moderate depths.

$$
\begin{gathered}
\text { T. } 8 \text { S., R. } 45 \text { E. } \\
\text { (pl. 4) }
\end{gathered}
$$

The relatively broad Bear Creek-Otter Creek divide trends northward near the eastern edge of the township. All streams are intermittent, and most of the township is drained by tributaries of Bear Creek, which flows northward through the middle of the township. Except in the northern part where the hills bordering Bear Creek valley are steep sided, the valley is wide and has gentle slopes. Large areas in the western, southern, and eastern 
parts of the township are rolling grassy uplands. There are scattered growths of pine trees near the margins of the Anderson clinker. The maximum relief is about 700 feet.

The exposed rocks consist of about 700 feet of interbedded lightyellow-gray sandstone, shale, and coal beds in the upper part of the Tongue River Member of the Fort Union Formation. An estimated additional 750 feet of the member lies beneath the surface. The thicker coal beds, particularly the Anderson bed, have produced much clinker in many parts of the township.

An east-trending normal fault, where a maximum stratigraphic displacement is about 100 feet down on the south, is present in the southern part of secs. 9 and 10 and the NE1/4 sec. 17. Data obtained from logs of wells drilled for oil and gas show that the rocks dip southwestward about 65 feet per mile.

Roland coal bed.-The clinker of the Roland coal bed, which is the top bed of the Tongue River Member, is present only in very small outliers in sec. 31 .

Smith coal bed.-The Smith coal bed, which is 210 feet below the Roland bed, crops out at many places in the southern and western parts of the township, but this coal bed and other beds between the Roland and Anderson beds are each less than 2 feet thick.

Anderson (No. 1) coal bed.-The Anderson coal bed is the highest coal bed of value in the township. Its position in most of the township is marked by a conspicuous band of clinker. Two incomplete sections of the coal measured in secs. 9 and 16 show thicknesses of 8 feet 7 inches and 6 feet 10 inches, respectively, and a complete section in sec. 26 shows a thickness of 14 feet. A thickness of more than 38 feet is reported in an old record of a well at locality 204 in the $\mathrm{NE}_{1 / 4}$, sec. 29. Large areas in the township are underlain by this coal bed.

Dietz (No. 2) coal bed.-The Dietz coal bed, which is about 60 feet below the Anderson bed, crops out extensively in the township in the slopes below the Anderson clinker. The thickness of the bed ranges from 8 feet 10 inches to 14 feet 2 inches, including a shale parting as much as 1 foot 1 inch thick.

Local coal bed.-A local coal bed, about 35 feet below the Dietz bed, was observed at several places in the township. It has a thickness of more than 2 feet only at locality 214 in the NW1/4 sec. 11, where it is 2 feet 9 inches thick, including a parting of shale 4 inches thick. 
Canyon (No. 3) coal bed.-The clinker of the Canyon coal bed, which lies 155 feet below the Dietz bed, is present in the northeastern part of the township and along the Bear Creek valley in the north-central part. The coal is 9 feet thick at locality 219 in the NE $1 / 4$ sec. 5 and more than 15 feet thick at locality 212 in the $\mathrm{S} 1 / 2$ sec. 10. These data, together with measurements of the Canyon coal bed in the southwestern part of the adjacent township to the east, suggest that the coal bed thickens southeastward across T. 8 S., R. 45 E.

Cook (No. 4) coal bed.-A coal bed, about 120 feet below the Canyon bed, herein correlated with the Cook coal bed, crops out in sec. 1 along the southwestern slope of Otter Creek valley. It is 3 feet thick at locality 215 near the north boundary of the NE1/4 sec. 1 and 6 feet 2 inches thick at locality 216 in the center of the $\mathrm{N} 1 / 2$ sec. 1 . The bed is generally about 5 feet thick in the northwestern part of the adjacent township to the east and in the region north of this township is present only locally.

Otter coal bed.-The Otter coal bed, which is about 150 feet below the Canyon bed, crops out in sec. 1 on the southwestern slope of Otter Creek valley. No measurements of its thickness were made in this township.

Wall coal bed.-The evidence of the Wall coal bed and other coal beds in the part of the Tongue River Member underlying this township, as revealed by outcrops in adjacent townships, indicates that coal beds other than those described in the above paragraphs are present in the relatively shallow subsurface.

$$
\begin{gathered}
\text { T. } 9 \text { S., R. } 45 \text { E. } \\
\text { (pl. } 4 \text { ) }
\end{gathered}
$$

The surface of T. 9 S., R.45 E., is part of a high rolling grasscovered plateau. The valleys of the intermittent streams are shallow. The rocks at the surface consist largely of interbedded shale, siltstone, and friable sandstone, all of which erode readily to form gentle slopes. A sequence of light-brown sandstone in the uppermost part of the Tongue River Member is more resistant than the beds above and below, and it forms ledges, particularly on the south- and west-facing slopes in the southern part of the township. Pine trees grow sparsely on these sandstone beds.

Of a total exposed sequence about 550 feet thick, the uppermost 210 feet is included in the Wasatch Formation, inasmuch as it lies above the Roland coal bed, which is considered to be the top bed of the Fort Union Formation. The rocks dip southwestward at 
about 60 feet per mile, according to data from the logs of wells drilled in the region for oil and gas.

Felix(?) coal bed.-A coal bed about 205 feet above the Roland bed, which is probably the Felix bed, is represented by a small area of clinker near the $\mathrm{S} 1 / 4$, cor. sec. 21 .

Arvada coal bed.-The Arvada coal bed, which is about 70 feet above the Roland bed and is the highest bed of coal in the township, crops out at many places in the south half of the township. Its thickness ranges from 3 feet 4 inches to 6 feet at the 17 localities where it was measured.

Roland coal bed.-The outcrop of the Roland coal bed is widespread in the south half and western part of the township. The bed is split into two benches at most places; the thickness of the upper bench ranges from 3 feet 2 inches to 7 feet 6 inches, and it is more than 5 feet thick at most places where it was measured. It is 5 feet 11 inches thick at a place 1,300 feet east and 500 feet south of the SW. cor. sec. 36 outside the mapped area. The lower bench is a little more than 3 feet thick at most localities.

Local coal bed.-A local coal bed 80 feet below the Roland bed crops out west of this township and is estimated to underlie 240 acres in this township (table 2).

Local coal bed.-A local coal bed that lies about 135 feet below the Roland bed ranges from 2 feet 1 inch to 4 feet 8 inches at seven localities where it was measured. The coal contains silicified stumps at two of the localities.

Smith coal bed.-A thin coal bed 210 feet below the Roland bed, believed to be the Smith bed, crops out at many places in the northern part of the township. Its thickness is less than 2 feet.

Anderson (No. 1) coal bed.-The Anderson coal bed is about 335 feet below the Roland bed. It lies near the surface in secs. 1,2 , and 3, where clinker has been formed. According to an old well record more than 12 feet of coal in this bed is present at a depth of 16-20 feet at locality 200 in sec. 11. Inasmuch as the Anderson bed is a thick bed where it was measured at many localities west, north, and east of this township, it likely is a thick bed under much of this township.

Other coal beds, including the Dietz and Canyon beds, underlie the township at shallow depth, according to data obtained by mapping outcrops in adjacent townships. 


\section{T. 7 S., R. 46 E. \\ (pl. 4)}

Most of T. 7 S., R. 46 E., is drained northwestward by Indian and Taylor Creeks, tributaries of Otter Creek, which flows northwestward across the southwesternmost part of the township. The stream valleys throughout most of the township are relatively broad, shallow, and flat bottomed and have gently sloping sides. The streams are intermittent. The clinker which rims the valleys forms prominent bare rock ledges only in the lower courses of the streams where the relief is somewhat greater than in the upper courses. Here the southward-facing slopes have patches of bare rock, which expose much interbedded gray shale and some light-tan to yellow sandstone. Pine trees grow on the clinker margins and on the surface for 500-1,000 feet back from the clinker outcrops. Trees grow sparsely on the slopes of most valleys.

The exposed rocks consist of about 650 feet of interbedded light-yellow-gray sandstone, shale, and coal beds in the upper part of the Tongue River Member of the Fort Union Formation. An estimated additional 500 feet of the member lies beneath the surface, and the uppermost part of the member, about 300 feet thick, has been removed by erosion. Data obtained from logs of wells drilled for oil and gas show that the rocks dip southwestward about 50 feet per mile.

Anderson (No. 1) coal bed.-A thick clinker at the horizon of the Anderson coal bed caps several high points in the township and suggests that the bed had been thick in the area. The baked condition of the rocks suggests that it is improbable that any of the coal of this bed remains unburned.

Dietz (No. 2) coal bed.-The Dietz coal bed, which is from 50 to 80 feet below the base of the Anderson clinker, is the uppermost bed of coal that crops out in the township. It is present in several small areas. Measured sections at four places suggest that the bed has an average thickness of about 8 feet.

Local coal bed.-A local coal bed, about 25 feet below the Dietz bed, crops out at several places in the western part of the township. The coal is 3 feet 11 inches thick at locality 268 in the SE1/4 sec. 18 and 3 feet 9 inches thick at locality 276 in the SE1/4 sec. 20.

Canyon (No. 3) coal bed.-The Canyon coal bed is about 155 feet below the Dietz bed in the western part of the township. The coal has burned along the outcrop at many places, and the posi- 
tion of the bed is marked by a conspicuous band of clinker. The coal bed is 25 feet 4 inches thick at locality 266 near the SW. cor. sec. 18, 9 feet 6 inches thick at locality 289 in the $S 1 / 2$ sec. 32 , and 7 feet 9 inches thick at locality 253 in the NW1/4 sec. 5 .

Local coal bed.-A local coal bed, about 55 feet below the Canyon bed, is thin, of poor quality, and of limited extent.

Cook (No. 4) coal bed.-A thin coal bed which lies about 105 feet below the Canyon bed and therefore near the horizon of the Cook bed, crops out widely but not continuously in the township. The thickness of the bed at the nine localities where it was measured ranges from 2 feet 6 inches to 10 feet 9 inches.

Otter coal bed.-The Otter coal bed, which in this township is 140 feet below the Canyon bed, is widespread. Its thickness ranges from 5 feet 11 inches to as much as 11 feet at seven of the localities where it was measured. In addition, a thickness of only 2 feet 7 inches was obtained at locality 275 in the SE1/4 sec. 21 , but not all the bed appears to be exposed.

Elk coal bed.-A thin coal bed, 255 feet below the Canyon coal bed, crops out in the valleys of the three main streams of the township. It appears to be equivalent to the Elk coal bed. Of 10 measurements of the bed, 4 feet 6 inches is the largest, and the coal contains one or more thin partings of shale at most places. Its outcrops are widespread, however, a fact suggesting that the bed is present in most of the township.

Dunning coal bed.-The outcrop of a coal bed, 345 feet below the Canyon coal bed, can be traced southeastward from T. 6 S., R. 46 E., into secs. 3 and 4 of this township. The Dunning coal is a thick bed (Warren, 1959, pl. 25) in parts of T. 6 S., R. 46 E., but it is thin and contains shale and bone in secs. 3 and 4 of this township.

More coal beds undoubtedly lie at relatively shallow depth in this township because they crop out along Otter Creek a few miles north of the township boundary.

$$
\text { T. } 8 \text { S., R. } 46 \text { E. }
$$

(pl. 4)

Much of T. 8 S., R. 46 E., is high rolling grassland, dissected by the valleys of Otter Creek, which flows slightly west of north in the westernmost part, and Pasture and Bradshaw Creeks, which flow northwestward across the central part of the township. All streams are intermittent. For the most part, the valleys are shallow, are grass covered and have gently sloping sides. Red clinker 
caps the slopes and forms rounded ledges at many places. Pine trees grow sparsely on the clinker for about one-fourth mile back from the outcrop and locally on the sandy slopes below the clinkers.

The exposed rocks consist of about 600 feet of interbedded light-yellow-gray sandstone, shale, and coal beds, which are in the upper part of the Tongue River Member of the Fort Union Formation. It is estimated that an additional 650 feet of the member lies beneath the surface and that the uppermost 100 or more feet has been removed by erosion. Data obtained from logs of wells drilled for oil and gas show that the rocks dip southwestward about 65 feet per mile. The maximum stratigraphic displacement along an east-trending normal fault in secs. 13 and 14 is about 100 feet down on the south.

Local coal bed.-A thin local coal bed 135 feet below the Roland bed occupies small areas in secs. 35 and 36 . It is 3 feet 5 inches thick including two thin partings of shale at locality 323 in the $\mathrm{S} 1 / 2$ sec. 35.

Smith(?) coal bed.-A coal bed, which is tentatively designated the Smith(?) coal bed, crops out in small areas in secs. 13, 24, and 25 . The bed commonly contains shale partings.

Anderson (No. 1) coal bed.-The Anderson coal bed, which lies 135 feet below the Smith bed, is the highest bed of value in the township. Its outcrop is marked by a prominent band of clinker in the east half of the township. Parts of the bed crop out and were measured at locality 322 in the $\mathrm{W} 1 / 2$ sec. 36 and at locality 324 in the E1/2 sec. 33. The data from these localities suggest that the thickness of coal generally exceeds 10 feet. Unburned Anderson coal is under less than 200 feet of cover in large areas in part of the township.

Dietz (No. 2) coal bed.-The Dietz coal bed, which may really be two closely associated beds, is about 50-80 feet below the Anderson bed. It crops out at many places in the township. The thickness of the coal ranges from 5 feet 3 inches at locality 303 in the NW1/4 sec. 2 to 9 feet $2+$ inches at locality 326 near the NW. cor. sec. 31 . Less confidence is placed in the identification of the coal bed at locality 326 than in that at the other eight localities where the bed was measured. The coal bed at locality 326 may really be somewhat lower stratigraphically than the Dietz bed.

Local coal bed.-A coal bed 30 feet below the Dietz bed was mapped locally. It is 2 feet 8 inches thick at locality 317 near 
the SW. cor. sec. 19. Reserves of coal are very small, and the bed is not included in table 2 .

Local coal bed.-A local coal bed was observed about 55 feet above the Canyon bed at several places in the township, but it is less than 2 feet thick at most places. It is 2 feet 8 inches thick, however, at locality 301 in sec. 4.

Canyon (No. 3) coal bed.-The Canyon coal bed is 180 feet below the Dietz bed in sec. 4 , where the interval between beds was measured. The bed crops out extensively as a thick clinker in the west half of the township. Partial sections of the bed were measured at localities 316 and 318 in the $\mathrm{S} 1 / 2$ sec. 19 and in the $\mathrm{N} 1 / 2$ sec. 30 , respectively. A complete section showing a thickness of 18 feet for the main bench of coal was measured at locality 315 near the E1/4, cor. sec. 22 . No measurement of the thickness of the coal bed was made in the northern half of the township, but measurements at outcrops in the adjacent township to the north suggest that it maintains a large thickness in the northern part of this township. The lack of baked rocks in large tracts in the interstream areas indicates that much coal in the Canyon bed is at a depth of less than 200 feet.

Cook (No. 4) coal bed.-A lenticular bed of coal lying 115 feet below the Canyon bed and therefore at the horizon of the Cook coal bed crops out on Bradshaw and Otter Creeks in the northwestern part of the township. The thickness of the bed measured at seven places ranges from 4 feet 2 inches at locality 309 in the SE $1 / 4$, sec. 7 to 11 feet 8 inches, including a parting of shale and bone 1 foot 11 inches thick, at locality 312 in the NE1/4 sec. 16. The coal bed thins rapidly eastward up Little Bradshaw Creek and was not mapped east of the SW1/4 sec. 4.

Otter coal bed.-A coal bed at the stratigraphic position of the Otter bed, 150 feet below the Canyon bed, crops out extensively along Otter and Bradshaw Creeks in the northwestern part of the township. Its thickness ranges from 4 feet 8 inches to 7 feet 1 inch at the ten localities where it was measured.

Elk coal bed.-A coal bed, believed to be the Elk bed, which is 260 feet below the Canyon bed, crops out only at locality 293 in the NW1/4 sec. 6 , where it is exposed in the wall of a small cave.

Abundant data on the outcrops of coal beds in the Tongue River Member in the region outside the boundary of this township indicate that several thick coal beds underlie the township at moderately shallow depth. 


\section{T. 9 S., R. 46 E. \\ (pl. 4)}

Most of T. 9 S., R. 46 E., is a high rolling grass-covered plateau. There are many intermittent streams which head in this township; some drain eastward into the Powder River and others drain northwestward into the Tongue River, which is west of the map area. Most of the surface is formed on rocks that are in the uppermost part of the Tongue River Member, above the Anderson coal bed. The lowermost part of the Wasatch Formation is at the surface in the southwestern part of the township. These rocks are interbedded shale, siltstone, and friable sandstone, rock types that erode easily and form gentle slopes. A sequence of lightbrown sandstone lying a short distance below the Roland coal bed, which is the top bed of the Tongue River Member, is more resistant than the beds above and below it and therefore forms a rather prominent ledge, particularly on south- and west-facing slopes; it also caps long narrow divides in many parts of the township. Pine trees grow sparsely on this sandstone sequence. The sandstone and associated beds are exposed in secs. 18, 19, and 20 and at other places.

The thick clinker of the Anderson coal bed forms prominent hummocks in the northwestern part of the township, and it is quarried at several places for local road metal.

Data obtained from the logs of wells drilled for oil and gas show that the rocks dip southwestward about 65 feet per mile.

The exposed rocks consist of about 500 feet of interbedded light-yellow-gray sandstone, shale, and coal beds. Of these rocks the uppermost 100 feet, which lies above the Roland coal bed, is included in the Wasatch Formation, inasmuch as the Roland coal bed is considered to be the uppermost bed of the Tongue River Member of the Fort Union Formation. The remaining 400 feet is included in the Tongue River Member. It is estimated that an additional 1,050 feet of the member lies beneath the surface. Burning of the thick coal beds has produced conspicuous red clinker in several parts of the township. A fossiliferous limestone (coquina) in the southwestern part of the township actually forms the roof of the Roland coal bed. The fossiliferous limestone roof of the Roland coal bed is exposed at locality 351 , and a fossiliferous sandstone about 75 feet lower is near locality 335 in the NW1/4, sec. 28.

Arvada coal bed.-The highest coal bed of significant thickness in the township is called the Arvada coal bed. It crops out near 
the crest of the divide in the southwestern part of the township. Its thickness is about $51 / 2$ feet at several of the eight localities where it was measured.

Roland coal bed.-The Roland coal bed, which lies 55 feet below the Arvada bed, is present high in the slopes in the southwestern part of the township. The thickness of the main bench of coal ranges from 5 feet 6 inches to 9 feet 7 inches at the five localities where it was measured. The roof of the coal in this township, as well as in some other parts of the coal field, is formed by a fossiliferous shale and a fresh-water limestone coquina. Bony coal and carbonaceous shale comprise the lowermost few feet of the bed.

Local coal bed.-A local coal bed lying about 90 feet below the Roland bed crops out extensively in this township but was not mapped everywhere because its thickness is commonly less than 2 feet. At three localities its thickness is at least 2 feet.

Local coal bed.-A local coal bed lying 135 feet below the Roland bed is slightly more than 2 feet thick at a few places. The thickness of the bed was measured at locality 330 in the NE1/4 sec. 12 and at locality 331 in the SW1/4 sec. 10.

Smith coal bed.-The Smith coal bed, which is 210 feet below the Roland bed, crops out at many places in the west half of the township but is less than 2 feet thick. Its outcrop was mapped in parts of secs. 6,7 , and 31 . It is as much as 2 feet thick only at locality 345 in the SE $1 / 4$ sec. 31 .

Anderson (No. 1) coal bed.-The outcrop of the Anderson coal bed has an irregular course northeastward across the northwestern part of the township. The bed lies 335 feet below the Roland coal bed. The thickness of the Anderson bed ranges from 9 feet 4 inches to 11 feet 3 inches at the four localities where its total thickness was measured. The coal contains silicified tree stumps at several places. Several measured sections in the adjacent township to the east suggest that the bed thickens eastward and southeastward from its outcrop to about 20 or more feet in the eastern part of the township.

Dietz (No. 2) coal bed.-The Dietz coal bed lies about 75 feet below the Anderson bed. The position of its outcrop is shown in secs. 4 and 5, but measurements of the thickness of the bed were not made. Thickness data for the bed in the southern part of the adjacent township to the north suggest that it is from $81 / 2$ to 12 feet thick. 
Data on the outcrops of thick coal beds in the Tongue River Member in the region adjacent to this township indicate that several thick coal beds underlie this township at depths of only a few hundred feet. The reserves of three of these beds based on data obtained from outcrops outside this township are shown in table 3.

T. 7 S., R. 47 E.

(pl. 5)

The eastern and southern parts of T. 7 S., R. 47 E., are hilly country but not so rugged as the breaks along the Powder River in the adjacent townships to the east. The grass-covered valleys are relatively shallow and have gently sloping sides that extend upward to the ledge of clinker at the top of the slopes. A large triangular area extending northward from sec. 21 and as much as 4 miles wide at the north boundary of the township is a treeless rolling grass-covered upland. Pine trees grow along the outcrops of the the clinker zones. The clinker of the Anderson coal bed is widespread in the south half of the township, but the slopes below and above it are gentle. The clinker of the Canyon coal bed is fairly extensive lower in the slopes in the western part of the township.

The exposed rocks consist of about 700 feet of interbedded lightyellow-gray sandstone, shale, and coal beds of the upper part of the Tongue River Member of the Fort Union Formation. The upper half of this sequence contains more shale than the lower half. It is estimated that the lower 600 feet of the member is below the surface. The uppermost $60 \pm$ feet of the member has been removed by erosion.

Data obtained from logs of wells drilled for oil and gas show that the rocks dip southwestward about 50 feet per mile.

Local coal bed.-The uppermost coal bed, which lies about 270 feet above the base of the Anderson coal bed, is exposed only on Diamond Butte in sec. 11 at locality 450 , where it is 2 feet 10 inches thick.

Local coal bed.-A local coal bed, which is about 210 feet above the base of the Anderson bed, is 2 feet 11 inches thick at locality 451 in sec. 11 near triangulation station "Diamond," but it is less than 2 feet thick at other localities where it was measured. A coal bed that is tentatively correlated with this local bed was mapped in much of the divide area in this and other townships to the south and west along the headwaters of Otter Creek and its tributaries. 
Smith coal bed.-Locally this coal bed is a few inches thick and therefore not mapped; it is tentatively correlated with the Smith bed of the southern part of the coal field and is about 80 feet below the local bed described above.

Anderson (No. 1) coal bed.-Three beds or splits of the Anderson coal bed are present in the northeastern part of the township. The upper and middle splits are about 20 feet apart, and the middle and lower splits are 10 feet apart. Because exposures are not continuous, some confusion arises in identifying these splits at localities where only one split is exposed.

Dietz (No. 2) coal bed.-The Dietz coal bed is about 70 feet below the Anderson bed. Another coal bed 20 feet higher, called the upper split of the Dietz bed, is more than 3 feet thick locally in the northeastern part of the township. This bed is less than 2 feet thick north of locality 456 in the SW1/4 sec. 12, but the main bed is widespread in the township. Exposures are not adequate to show whether the upper split is present everywhere. Silicified tree stumps are abundant in the coal in the northern part of the township.

Canyon (No. 3) coal bed.-The Canyon coal bed is 100 feet below the Dietz bed. Five measurements (pl. 5) suggest that its thickness varies greatly. Its thickness exceeds 12 feet in three localities in secs. 4, 17, and 21 and, as indicated by a thick clinker at the Canyon horizon, the bed is thick in the southern and the western parts of the township. It apparently is thin only in the northeastern part of the township.

Cook (No. 4) coal bed.-The Cook coal bed, which is generally about 10 feet thick, is about 100 feet below the Canyon bed. It crops out on Taylor and Indian Creeks in the western part of the township and was measured at six localities.

Otter coal bed.-The Otter coal bed, which is about 155 feet below the Canyon coal bed. crops out on Indian Creek near the west boundary of the township near the southwest corner of the township. It is 4 feet 7 inches thick at locality 416 in the SW1/4 sec. 31. The area underlain by the bed is too small to be listed in table 3. The presence of a coal bed believed to be equivalent to the Otter bed is indicated by a band of clinker on the south fork of Taylor Creek in sec. 18. Outcrops to the west, north, and east indicate that the stratigraphic sequence underlying this township at relatively shallow depth probably contains several moderately thick beds of coals. 


\section{T. 8 S., R 47 E.}

(pl. 5)

The east border of T. 8 S., R. 47 E., is occupied by rugged hills and deep canyons, which are part of the dissected margin of a high plateau lying west of the Powder River. Most of the rest of the township is part of the plateau and is rolling grassland. Pine trees grow on clinker at the east margin and to a much lesser extent in the western and north-central parts of the township, where the clinker slopes are subdued. These slopes are generally grass covered and descend into broad valleys; only the ledges formed by the clinker are precipitous. The clinker of the Anderson coal bed is the most extensive of that of the beds in the township. The rolling grass-covered country above the Anderson clinker has a few exposures of shale and light-tan siltstone, and some 200-300 feet above the Anderson, a ledge-forming tan sandstone is $6-10$ feet thick. This sandstone underlies a considerable area of the rolling grassland. Locally, such as at Miles triangulation point near the center of the south boundary of sec. 32 , rocks 30-40 feet thick overlie the sandstone and underlie a grassy knoll.

The exposed rocks consist of about 500 feet of interbedded lightyellow-gray sandstone, shale, and coal beds of the upper part of the Tongue River Member of the Fort Union Formation. The uppermost part of the member, about 200 feet thick, has been removed by erosion. It is estimaed that an additional 750 feet of the member lies beneath the surface.

Data obtained from logs of wells drilled for oil and gas show that the rocks dip southwestward about 50 feet per mile. A normal fault, trending east, crosses the northern part of sec. 18. The displacement of the rocks along the fault is about 100 feet down on the south.

Smith(?) bed.-Two closely associated beds, the lower of which is probably the Smith bed, crop out at several places near the crest of the Otter Creek-Powder River divide. The thickness of the coal in each of the beds is less than 2 feet, and so neither was mapped. The lower or Smith(?) bed is 135 feet above the Anderson bed.

Anderson (No. 1) coal bed.-The Anderson coal bed is, stratigraphically, the highest thick coal bed in the township. Its natural burning has formed a prominent clinker on both sides of the Otter Creek-Powder River divide. An incomplete thickness of the coal bed at locality 402 in sec. 33 shows the bed to be at least 13 feet 
thick. A large area in the central part of the Otter Creek-Powder River divide wherein clinker is absent suggests that this broad area contains a thick Anderson coal bed at shallow depth.

Dietz (No. 2) coal bed.-The Dietz coal bed is about 55 feet below the Anderson bed. Its thickness ranges from 3 feet 9 inches at locality 411 in the SW1/4 sec. 1 to $10+$ feet at locality 406 near the center of sec. 20 . The data from the nine places where the bed was measured suggest that it thins from west to east across the township. Except at locality 404 in sec. 35, outcrops of the Dietz bed were not seen, and it was not mapped south of the Flood Creek-Thompson Creek Divide.

Canyon (No. 3) coal bed.-The Canyon bed is about 105 feet below the Dietz bed. It is marked by a prominent band of clinker on both sides of the Otter Creek-Powder River divide. The thickness of the coal was measured at four widely spaced localities in the township These measurements together with others in the region outside the township suggest that the bed is probably more than 12 feet thick throughout most of the township.

Cook (No. 4) coal bed.-The clinker of the Cook coal bed was mapped on Thompson Creek in sec. 25. Although no measurement of the thickness of the bed was made here, it is 5 feet 2 inches thick at one place and 6 feet 11 inches thick at another place in the Thompson Creek Valley less than a mile east of this township. The average depth of the Cook bed below the Canyon bed is 160 feet in the adjacent township to the east. The bed mapped in sec. 25 lies at a much smaller interval below the Canyon bed and may be a local bed, somewhat younger than the Cook bed. Undoubtedly several beds of coal that crop out along the Powder River valley a few miles east of the township boundary are present in the subsurface in this township. Reserves for two of these beds, Otter and a local bed, are shown in table 3.

$$
\text { T. } 9 \text { S., R. } 47 \text { E. }
$$

(pl. 5)

T. 9 S., R. 47 E., is occupied by rugged clinker-capped hills and ridges and deep canyons that form a part of the dissected margin of a high plateau. The plateau lies northwest of the Powder River valley, which crosses the southeasternmost part of the township. Here the flood plain of the river is one-half to three-fourths mile wide. The river flows northeastward in a meandering course about 15 feet below the flood plain. Line, 
Bradshaw, Rough, and Trail Creeks are intermittent tributaries that flow southeastward toward the Powder River. A high grasscovered rolling surface on the plateau, 1-2 miles wide, occupies the westernmost part of the township. The thick clinker of the Anderson coal bed forms the rims of the deep canyons and the surface of the high plateau and interstream ridges and other clinker beds are in the canyon walls. The clinker on the margin of the upland supports a growth of pine trees.

The exposed rocks consist of about 650 feet of interbedded lightyellow-gray sandstone, shale, and coal beds which are in the upper two-thirds of the Tongue River Member of the Fort Union Formation. It is estimated that the uppermost 200 feet of the member has been removed by erosion and that an additional 600 feet lies beneath the surface.

Data obtained from logs of wells drilled for oil and gas show that the rocks dip slightly south of west about 50 feet per mile. A small east-northeast-trending normal fault, along which the rocks are downthrown on the north, extends into the southern part of sec. 32, and in a small area just north of the fault the rocks $\operatorname{dip} 2^{\circ}-3^{\circ}$ northwestward.

Local coal bed.-A coal lens near the stratigraphic position of the Smith bed, 125 feet above the Anderson bed, is the uppermost coal bed exposed. It is 2 feet 11 inches thick, including a 3 -inch shale parting, at locality 400 near the NE. cor. sec. 5 and was traced only a few hundred feet on each side of locality 400 . Reserves for this bed are not shown in table 3 because of its small area and small thickness.

Anderson (No. 1) coal bed.-The Anderson coal bed crops out in many places in the western part of the township. Its thickness ranges from 5 feet 6 inches to 25 feet, and it is generally more than 15 feet thick at the 11 places where it was measured. The burning of such a thick coal bed has formed an unusually thick clinker. The unbaked appearance of the rocks one-eighth to onefourth mile back from the outcrop in many places, however, indicates the presence of unburned coal in large areas.

Dietz (No. 2) coal bed.-The Dietz coal bed is about 45 feet below the Anderson bed. It crops out at many places on the main interstream divides. Its thickness ranges from 2 feet 11 inches to 8 feet 4 inches at the nine places where it was measured in this township. The bed contains partings of bony coal and shale at several localities. It is 7 feet thick, including two thin partings at 
an outcrop 1,300 feet southeast of the SW. cor. sec. 32 outside the mapped area.

Canyon (No. 3) coal bed.--The Canyon coal bed is about 90 feet below the Dietz bed. It has burned and formed a prominent clinker in much of the township. The bed was measured at four widely separated localities where the thickness of the main bench ranges from 3 feet 6 inches to 16 feet 5 inches.

Cook (No. 4) coal bed.-A coal bed that crops out extensively about 120 feet below the Canyon bed, on Line and Bradshaw Creeks, and locally on the south side of Rough Creek likely is equivalent to the Cook bed of other parts of the coal field, Generally, the bed appears to be less than 2 feet thick, or is absent in the north half of the township. Measurements at nine places on Line, Bradshaw, and Rough Creeks in the south half of the township show that the thickness ranges from 3 feet 10 inches to 9 feet 7 inches.

No. 4a coal bed.-A coal bed crops out locally 190 feet below the horizon of the Canyon bed on Rough, Bradshaw, and Line Creeks in the eastern part of the township. Its thickness ranges from 4 feet, including a parting 1 foot thick, to 5 feet 11 inches at the five localities where it was measured.

No. 5 coal bed.-What appears to be a sequence containing several coal beds, lying about 230-280 feet below the Canyon coal bed, crops out on Bradshaw, Rough, Trail Creeks in the eastcentral part of the township. Three beds of coal in a total sequence 43 feet 2 inches thick were measured at locality 384 in the SE1/4, sec. 23. One bed of coal was exposed at localities $383,387,366$, and 398 , and two beds were exposed at locality 396 . A bed 19 feet 4 inches thick is exposed at locality 361 in the $\mathrm{SE} 1 / 4$, sec. 35 . It may be that these beds represent only a part of the sequence present. The bed designated " 5 " is near the stratigraphic position of the Wall coal bed of the adjacent Spotted Horse coal field to the south (Olive, 1957, p. 46).

\section{T. 7 S., R. 48 E.}

(pl. 5)

Bloom and Plum Creeks, tributaries of the Powder River, flow southeastward across T 7 S., R. 48 E. They are intermittent streams ; their valleys in the eastern half of the township are about half a mile wide. The interstream areas are rugged and are char- 
acterized by steep-sided clinker-capped ridges and hills, and there are many areas of bare rock on the south-facing slopes. The grasscovered valleys in the west half of the township are narrow and shallow, and their slopes terminate in a ledge of red clinker which supports a growth of pine trees. The bordering hills and ridges have rounded slopes.

Most subdivisions of the Tongue River Member are fairly well exposed on the north side of Bloom Creek. Here Hass measured much of the stratigraphic section of the Tongue River Member, which is described in the section "Fort Union Formation (Paleocene)." The clinker of the Cook coal bed is a conspicuous feature; it is well exposed, capping the high flat-topped butte in the SE $1 / 4$, sec. 11 and NE1/4, sec. 14, north of Bloom Creek and west of the eastern boundary of the Custer National Forest. Directly below the clinker is a bed of gray shale about 10 feet thick, underlain by a very light gray sandstone about 40 feet thick that is prominently exposed on the southwestern face of the butte, at many places northwestward along Bloom Creek, and along the south fork of Bloom Creek. Much of the bed is exposed on the north side of the main road in the $\mathrm{SE} 1 / 4 \mathrm{SW} 1 / 4$ sec. 7 . A long slope of gray shale interbedded with chocolate-colored carbonaceous shale underlies the light-gray sandstone. The shale is underlain by a light-tan sandstone and shale sequence 125 feet thick. Parts of this standstone and shale unit form conspicuous ledges in the slope on Bloom Creek, in the slopes of gulches southward from Bloom Creek to beyond Plum Creek, in the hills northwest of the Powder River in the northeastern part of T. 8 S., R. 48 E., and also northeastward from Bloom Creek for several miles into the northwestern part of T. 7 S., R. 49 E. Farther south in T. 9 S., R. $48 \mathrm{E}$., east of the Powder River, the Tongue River Member appears to contain more shale than on Bloom Creek, and the ledge-forming sandstone and shale unit described above is not apparent. Several beds of ledge-forming light-tan sandstone crop out in this southern area, however, but their precise correlation with similar beds on Bloom Creek is not known.

A sequence of gray and brownish-gray shale $\mathbf{7 5}$ feet thick, underlying the sandstone and shale sequence described above, is exposed on the side of the hill on the forest boundary half a mile north of Bloom Creek. The shale in turn overlies a sequence 80 feet thick that consists of two beds of ledge-forming light-brown sandstone and a middle unit of sandy shale. This sandstone 
sequence forms tan ledges on the southwestern side of Bloom Creek in sec. 30 and caps the butte in the SW1/4 sec. 19, T. 7 S., R. $49 \mathrm{E}$., on the northeastern side of Bloom Creek.

The rocks associated with the Canyon coal bed in the northwestern part of T. 7 S., R. 48 E., are shaly and form relatively gentle slopes. Shale is predominant in the 450 -foot-thick rock sequence directly above the Canyon coal and forms grass-covered slopes westward up to triangulation station "Diamond" in T. 7 S., R. 47 $\mathrm{E}$. The Dietz and Anderson sequence of coal and intervening shale beds forms clinker in the southwestern part of T. 7 S., R. $48 \mathrm{E}$.

Data obtained from logs of wells drilled for oil and gas show that the rocks dip southwestward in this township about 45 feet to the mile.

Anderson (No. 1) coal bed.-A thick clinker at the stratigraphic position of the Anderson coal bed in the southwestern part of the township indicates that the coal bed had been relatively thick in the area. Nearby, at locality 429 in the NW1/4 sec., 24, T. 7 S., R. 47 E., the thickness of the Anderson bed is more than 9 feet. Coal of comparable thickness is probably present at a shallow depth in parts of secs $19,20,31$, and 32 , where the unbaked appearance of the rocks indicates that the Anderson bed has not been burned.

Dietz (No. 2) coal bed.-The Dietz coal bed, about 50 feet below the Anderson bed, is 5 feet 9 inches thick where it crops out at locality 468 in the SW1/4 sec. 5 . This coal may really be equivalent to a lower split of the Anderson coal bed as mapped west of this township. This bed underlies the western and southern parts of the township, and measurements of the coal at localities a short distance west and southwest of the township indicate that it is about 5 feet thick.

Canyon (No. 3) coal bed.-Although the Canyon coal bed, which is 145 feet below the Dietz coal bed, crops out at only two localities (loc. 469 in the SE1/4 sec. 5 and loc. 476 in the SE1/4 sec. 8) in the township, its position is indicated by a widespread conspicuous thick clinker. A thickness of more than 15 feet at each of the two exposures in secs. 5 and 8 and a generally large thickness in the region suggest that a thickness of about 15 feet may be expected for the coal bed in the many parts of the township where it has not been burned.

Cook (No. 4) coal bed.-The Cook coal bed, about 125 feet below the Canyon coal bed, crops out in the valleys of Bloom and Plum 
Creeks, where the coal bed was measured at five localities (loc. 473 and 474 in the NW1/4, sec. 10 , loc. 485 in the SE1/4 sec. 21 , loc. 486 in the $\mathrm{SE} 1 / 4$, sec. 29 , and loc. 492 in the NW1/4 sec. 36). The thickness of the bed is about 11 feet in the northeastern part of the township, but it is only 7 feet 3 inches at locality 492 ; this decrease suggests that the thickness becomes less southeastward. The position of the bed is marked by a prominent red band of clinker. The thick clinker and the data from the measured sections suggest that the bed has a thickness of from 7 to 11 feet in most of the township.

A thin coal bed, which is designated herein as a lower bench of the Cook bed, was observed at many places about 20 feet below the main bed. This bed was not mapped separately, although it may be equivalent to the Otter coal bed of the area to the west. Sections of the lower bench were measured at six localities. These sections show a southward thinning of the bed from about 6 feet in sec. 10 to about 3 feet at the south boundary of the township.

No. 5 coal bed.-This bed, about 140 feet below the Cook bed and possibly equivalent to the Elk coal bed, crops out in the eastern part of the township along the valleys of Bloom and Plum Creeks. The coal was measured at locality 471 in the NE1/4 sec. 11 , locality 475 near the center of W1/2 sec. 10, locality 487 in the $\mathrm{N} 1 / 2$ sec. 26 , and locality 489 in the NE1/4 sec. 25 . The thickness of the bed is 5 feet 9 inches at locality 489 and decreases northwestward to 3 feet 1 inch of poor or shaly coal at locality 475 . The coal bed was traced only a short distance northwest of locality 475 and could not be found on the south fork of Bloom Creek west of the E1/2 sec. 16.

No. 6 coal bed.-This bed, which is about 345 feet below the Canyon coal bed and 220 feet below the Cook bed, crops out along the valley of Bloom Creek from the east edge of the township west as far as sec. 15 and along the valley of the Powder River in secs. 25 and 36 . The No. 6 coal is really composed of three closely associated beds or benches of coal. The lowest bench is 21 feet 10 inches thick at locality 488 in the $\mathrm{NE}^{1 / 4}$, sec. 25 and is 23 feet 11 inches thick (base concealed) at locality 493 in the SW1/4 sec. 36. Only the top bench of the coal bed was measured at locality 470 in the SW $1 / 4$ sec. 12 . The coal bed is at shallow depth and may be adaptable to strip mining in parts of secs. $9,10,15$, and 16 . The available data suggest that it underlies most of the township.

No. 8 coal bed.-This bed, ranging in thickness from 2 feet 11 
inches at locality 494 in the SW1/4 sec. 36 to 10 feet 2 inches at locality 482 in the SE1/4 sec. 24 , crops out in the valley of Bloom Creek near the east boundary of the township and in the valley of the Powder River in sec. 36. Northwestward on Bloom Creek it passes beneath alluvium in the $\mathrm{NW}^{1 / 4}$ sec. 24 and the $\mathrm{SW} 1 / 4$ sec. 13. The lower bench of the coal bed at locality 482 and at locality 491 in the NE1/4 sec. 36 contains petrified wood.

Cache (No. 9) coal bed.-The Cache coal bed, which is about 170 feet below the No. 6 coal bed, crops out only at locality 490 on the east boundary of sec. 36, where an upper bench 6 feet 10 inches thick is separated from a lower bench 3 feet thick by a bed of black shale 3 feet 7 inches thick. The Cache bed has an average thickness of about 9 feet in the adjacent southern part of T. 6 S., R. 49 E., to the northeast (Warren, 1959, pl. 26). It seems probable, therefore, that the bed is extensive in the subsurface of this township.

Several coal beds are present in the lower part of the Tongue River Member where it crops out a few miles northeast of this township (Warren, 1959, pl. 26). Therefore, it is reasonable to conclude that additional coal beds are present in the shallow subsurface of this township.

T. 8 S., R. 48 E.

(pl. 5)

The Powder River flows northeastward from the SW. cor. sec. 33 , across T. 8 S., R. 48 E., to the SE $1 / 4$ sec. 1 . The width of its flood plain generally is about 1 mile. The river flows in a meandering channel about 15 feet below the flood plain. Much of the flood plain is farmland. Buffalo Creek is the main intermittent tributary to the southeast. The valley of Buffalo Creek is grass covered and is nearly a mile wide; its gentle slopes are flanked by steepsided hills and by ridges capped with clinker. The clinker supports a growth of pine trees on its outcrops, but the slopes below the clinker are largely bare rock. The part of the township lying northwest of the Powder River is rugged; in succession from southwest to northeast, Thompson, Flood, Spring, Dutch, and Plum Creeks are southeastward-flowing intermittent tributaries. Their valleys are narrow, and their sides, mainly bare rock, are steep. Most of the narrow flat-topped divides is floored by a thick clinker formed by the natural burning of the Dietz and Anderson coal beds. The ledge-forming sandstone that lies between the Cook and No. 5 coal beds and the sandstone that lies between the No. 5 
and No. 6 coal beds, which are known on Bloom Creek to the north, are widely exposed in this township on the slopes northwest of the Powder River. In the rugged country southeast of the Powder River these sandstone units are not conspicuous. The exposed sequence, including these zones, appears to contain more shale, and the sandstone units, if present, are likely shaly, silty, or less firmly consolidated than they are farther north.

The exposed rocks consist of about 750 feet of sandstone, shale, and coal beds which are the middle part of the Tongue River Member of the Fort Union Formation. The uppermost 300-350 feet of the Tongue River Member has been eroded, and about 350 feet of the lower part lies beneath the surface. There are red bands of clinker on the ridge areas of the township; this red is a sharp contrast to the general light-yellow-gray of the rocks.

The rocks in the township dip southwestward about 50 feet per mile, according to data from logs of wells drilled for oil and gas. Two of the wells are in T. 8 S., R. 48 E. The westerly dip of the rocks is readily observable in the exposed rocks in Buffalo Creek valley and in other valleys southeast of the Powder River.

Anderson (No. 1) coal bed.-With the possible exception of very small ridge areas in the northern part of secs. 5 and 6, the Anderson coal bed has been burned, and its clinker caps the highest ridges in the northwestern and southeastern parts of the township.

Dietz (No. 2) coal bed.-The Dietz coal bed is about 50 feet below the Anderson bed. It is 5 feet thick at locality 498 in the NW1/4, sec. 6 and 4 feet 6 inches thick at locality 499 in the SW1/4 sec. 6. The bed was mapped separately in secs. 6 and 7 ; elsewhere northwest of the Powder River it forms a clinker that appears to merge with the clinker of the overlying Anderson bed. Only one clinker was mapped, and the presence and the thickness of the Dietz coal bed are conjectural. A coal bed mapped and identified as the Cayon bed in the southern part of the township may really be the Dietz bed.

Canyon (No. 3) coal bed.-The Canyon coal bed lies from 50 to 100 feet below the Dietz bed; the distance between these coal beds decreases southeastward. The thickness of the Canyon coal ranges from 10 feet-its top is concealed-to 14 feet 1 inch at five localities northwest of the Powder River and to 8 feet 1 inch at locality 579 in sec. 34 southeast of the river. These data obviously suggest that the thickness of the coal bed decreases southeastward. An upper bench of coal, 1 foot 6 inches to 1 foot 10 inches thick, lies 
about 5 feet above the main bed at localities 515 and 516 in sec. 10 .

Local coal bed.-Several thin lenses of coal are present in the 160-foot-thick interval between the Canyon and Cook coal beds. Most of them are less than 2 feet thick and were not mapped. A coal bed about 110 feet below the Canyon bed is 5 feet 6 inches thick at locality 557 in the SE1/4, sec. 19. This thickness persists only a short distance along the outcrop of the bed, however.

Cook (No. 4) coal bed.-The Cook coal bed lies about 160 feet below the Canyon coal bed. Sections of the bed were measured at 21 places. It is thick and persistent throughout most of the township and ranges in thickness from 10 to 16 feet in the northcentral and east-central part of the township and from 3 feet 8 inches to 6 feet 11 inches in the southern part.

No. $4 a$ coal bed.-A few thin lenticular beds of coal, commonly less than 3 feet thick, are present northwest of the Powder River at various intervals below the Cook bed. The upper one, No. 4a coal bed, lying 40-50 feet below the Cook bed, was mapped northeastward from the N1/2 sec. 19 on the north side of Flood Creek to about the center of the $\mathrm{S} 1 / 2$ sec. 10 , and its thickness was measured at eight localities.

Local coal bed.-A coal bed lying about 20 feet below the horizon of No. 4a coal bed was mapped for about half a mile in the $\mathrm{NE} 1 / 4$, sec. 29 ; it is 2 feet 6 inches thick at locality 564 .

No. $4 b$ coal bed.-This bed lies 50 feet below the local bed at locality 564 and was mapped on both sides of Flood Creek through parts of secs. $28,29,20$, and 21 .

No. 5 coal bed.-A coal bed, which is about 200 feet below the Cook bed, herein called No. 5 coal bed, was mapped throughout the township. Its thickness was measured at 19 localities.

No. 5 a coal bed.-A coal bed called No. 5 a, lying between No. 5 and No. 6 coal beds, crops out and was mapped for about threefourths mile in the $\mathrm{SE} 1 / 4$, sec. 29 and the $\mathrm{NE} 1 / 4$ sec. 32 . It has two thin benches of coal 1 foot 4 inches and 2 feet thick separated by a bed of shale 10 inches thick at locality 583 in the NE1/4 NE1/4 sec. 32. No reserves are shown for this thin bed in table 3 .

No. 6 coal bed.-This bed, which is tentatively correlated with the Pawnee coal bed, is widely distributed and has a wide range in thickness in the township. Its thickness was measured at nine localities, where it ranged from 2 feet to as much as 13 feet.

No. 7 coal bed.-A coal bed lying 30 feet below No. 6 was mapped from a place in the $\mathrm{SE} 1 / 4 \mathrm{NW}^{1 / 4}$ sec. 24 southeastward a 
short distance, thence northwestward around a prong of land in the $\mathrm{S} 1 / 2$ sec. 13 and past the township boundary in the NE1/4 sec. 24. It is 5 feet thick at locality 541 in the NE1/4 sec. 24 .

No. 8 coal bed.-This bed is about 45 feet below No. 7. Its thickness ranges from 2 feet 8 inches to 7 feet 7 inches at 12 localities distributed through the eastern half of the township where the bed was measured.

No. 8 a coal bed.-This bed that lies from 10 to 25 feet below No. 8 was mapped separately in the eastern part of the township. It was measured at three localities.

Cache (No. 9) coal bed.-The Cache coal bed crops out only in the northeastern part of the township a short distance above the alluvium of the Powder River valley floor. It ranges in thickness from 2 feet 6 inches to 2 feet 8 inches at the four places where it was measured.

$$
\begin{gathered}
\text { T. } 9 \text { S., R. } 48 \text { E. } \\
\text { (pl. 5) }
\end{gathered}
$$

The Powder River flows northeastward in a meandering course across the northwestern part of T. 9 S., R. 48 E. The flood plain of the river ranges in width from one-half to three-fourths mile; much of it is farmland. From southwest to northeast, the intermittent tributaries-Bitter, Dry, Jenkins, Bootjack, and Buffalo Creeks-flow toward the Powder River from the southeast. Bitter and Buffalo Creeks have wide grass-covered valleys flanked by high rugged hills and ridges; the other tributaries are in narrow steep-sided gulches. Much of the township's surface is clinkercapped steep-sided bare ridges and hills. Most of the high ridges are capped by a thick clinker of the Dietz coal bed. Pine trees grow on the clinker outcrops and along the margins of the flat-topped mesas.

The bare slopes expose a sequence of the Tongue River Member of the Fort Union Formation about 700 feet thick, which consists of interbedded gray and dark-gray shale, brownish-black carbonaceous shale, and small amounts of light-tan sandstone, some of which form ledges. The main sandstone units between the Nos. 6 and 4 coal beds, which are conspicuous on the north side of Bloom Creek in T. 7 S., R. 48 E., could not be identified in this township. The general appearance of the outcrops suggests that there is more shale here than at Bloom Creek and, if the sandstone units which are conspicuously exposed at Bloom Creek are pres- 
ent, they contain more shaly beds and therefore fail to form prominent ledges.

The rocks dip westward about 50 feet per mile according to data obtained from logs of wells drilled for oil and gas. The westward dip is readily observable in the exposed rocks in much of the township.

Anderson (No. 1) coal bed.-The highest clinker that was mapped is that of the Anderson coal bed; it caps the divides in parts of secs. 1, 6, 25, 26, 35, and 36. Although the Anderson coal is not exposed, the unaltered condition of the rocks suggests that it may be present in a few small areas in secs. 25 and 36.

Dietz (No. 2) coal bed.- The clinker of the Dietz coal bed, which is about 40-50 feet below the Anderson coal bed, crops out extensively on the high divides in the eastern part of the township. Local areas in which the coal appears to be unburned are in secs. $13,14,23-25$, and 36. Measurements of the thickness of the coal at three places within half a mile of the township boundary (at loc. 658,637 , and 638 in secs. 30 and 31, T. 9 S., R. 49 E.) indicate its thickness may be as much as 15 feet in this township.

Canyon (No. 3) coal bed.-A band of clinker northwest of the Powder River valley marks the position of the Canyon coal bed as about 70 feet below the clinker of the Dietz coal. The Canyon bed is 10 feet 4 inches at locality 589 in the NW1/4 sec. 6 In the area southeast of the Powder River this bed is widespread, but it has burned almost everywhere along its outcrop. The thickness of the coal was measured in secs. $11,14,23$, and 35 , however, where it ranges from 8 feet, base concealed, to 14 feet 5 inches.

Cook (No. 4) coal bed.-The Cook coal bed lies about 140 feet below the Canyon bed. The coal is underlain by a thick unit of black to brown carbonaceous shale, which commonly contains large gypsum crystals. Sections of the coal measured at nine widely spaced localities and a continuous band of clinker indicate that the coal bed persists throughout the township. Its thickness ranges from 3 feet 6 inches to 7 feet 5 inches at the localities where it was measured.

Nos. $4 a$ and $4 b$ (local).-Two local coal beds, generally thin, are at intervals of about 70 and 100 feet below the Cook bed at many places in the township. Northwest of the Powder River except at locality 591 near the SW. cor. sec. 6, the upper of these beds, herein called No. 4 a coal bed, is less than 2 feet thick or is absent. The bed is 2 feet 3 inches thick at locality 591. Southeast of the 
Powder River, a coal bed believed to be No. 4a trends southeastward from near the E1/4 cor. sec. 21 , and its thickness ranges from 2 feet 4 inches at locality 615 in the SW1/4 sec. 22 to 11 feet 8 inches at locality 635 in the SW1/4 sec. 35 .

The lower of the two local beds, herein called No. $4 \mathrm{~b}$ coal bed, is generally less than 2 feet thick and was not mapped in most of the township. West of the Powder River it is 2 feet thick in a knoll at locality 595 in the NE1/4 sec. 5. Southeast of the Powder River, its thickness ranges from 2 feet to 3 feet 3 inches at the six localities where it was measured.

No. 5 coal bed.-A coal bed, herein called No. 5, which is about 170 feet below the Cook (No. 4) bed and about 310 feet below the Canyon bed, is widespread in the township. Its thickness was measured at 18 localities, where it ranges from 2 feet 1 inch to 7 feet 3 inches.

No. 5 a coal bed.-A local coal bed, which occurs at about the stratigraphic position of No. $5 \mathrm{a}$ in the adjacent township to the north, crops out for a short distance in Dry Creek valley.

Coal beds in the subsurface.-Several beds of coal are doubtless present at depths of less than 300 feet in the Powder River valley. Core drilling by the U.S. Bureau of Reclamation in 1948 at localities $605 \mathrm{a}, 605 \mathrm{~b}$, and $605 \mathrm{c}$ in secs. 18 and 19 penetrated two beds of coal at a depth of about 75 feet. The upper bed, 14 feet to 15 feet 11 inches thick, is separated from the lower bed, 4 feet 11 inches to 5 feet 5 inches thick, by a bed of shale 3 feet 2 inches to 5 feet 7 inches thick.

\section{T. 7 S., R. 49 E.}

(pl. 6)

The Powder River flows northeastward in a flat-bottomed valley across T. 7 S., R. 49 E. The flood plain of the river is from 1 to $11 / 2$ miles wide, and the river bed is about 15 feet below the flood plain. Bay Horse and Buttermilk Creeks flow intermittently northwestward into the river, and Fire Gulch and Pinto and Bloom Creeks flow intermittently southeastward into it. The valleys of the northwestward-flowing tributaries, particularly that of Bay Horse Creek, have broad grass-covered gently inclined slopes devoid of trees. The valley of Bay Horse Creek is as much as a mile wide, and the flood plain of that creek is one-eighth to one-fourth mile wide. The valleys of Pinto and Bloom Creeks are narrower and are bordered by the steep slopes of deeply dissected interstream 
ridges, which are mostly grass covered. Stretches of steeply sloping bare rock are on the higher hills and ridges. Patches of pine trees are common and are most abundant on clinker beds and clinker-strewn slopes. The most conspicuous features of Buttermilk valley and of the lower mile of Bay Horse valley, particularly the north sides of the valleys, are the exposures of the thick orange-red clinker of the Cache coal bed and of the thick light-gray bed of sandstone directly below it.

The rocks dip slightly south of west at about 30 feet per mile according to data obtained from logs of wells drilled for oil and gas. The westerly dip is observed in outcropping rocks in Bay Horse Creek valley.

Canyon (No. 3) coal bed.-Clinker formed by the burning of a coal bed, tentatively identified as the Canyon bed, occupies small areas on the crests of ridges in the $\mathrm{S} 1 / 2$ sec. 7 and the N1/2 sec. 18. Apparently all the coal burned.

Cook(?) (No. 4) coal bed.-Though burned along and well back from the outcrop the Cook(?) coal bed is probably unburned in parts of secs. 7 and 18. It is 9 feet 8 inches thick, including 3 feet of shaly coal at the base at locality 785 in the SW1/4,SE1/4 sec. 7 . The area of unburned coal is very small, and so it is not shown in table 3. The clinker that caps several buttes on the ridge in sec. 33, southeast of the Powder River, was tentatively identified as that of the Cook bed.

Local coal bed.-A local coal bed about 25 feet below the Cook (?) bed was mapped in a part of the N1/2 sec. 5. It is 2 feet 4 inches thick at locality 794 in the NE1/4 sec. 5 , but the extent of the bed is too small to warrant its inclusion in table 2. The bed crops out at many places northwest of the Powder River, but it is not shown on the map because it is less than 2 feet thick.

No. 5 coal bed.-A coal bed about 95 feet below the Cook(?) bed and herein correlated with the No. 5 bed of other parts of the mapped area crops out extensively northwest of the Powder River. Its thickness ranges from 4 feet 5 inches to 5 feet 8 inches at eight of the localities where it was measured northwest of the Powder River. The bed is present in sec. 33, high on the divide between the Powder River and Bay Horse Creek. In the NE1/4 sec. 33, at locality 757 , the bed is 7 feet 11 inches thick, including a parting of shale 1 foot 1 inch thick that is 1 foot 2 inches below its top.

No. 6 coal bed.-A coal bed lying 175 feet below the Cook(?) bed and herein correlated with the No. 6 coal bed forms a con- 
spicuous clinker along most of its outcrop. Its clinker caps many buttes in secs. 23-26 and secs. 35 and 36. Its thickness was measured at five localities, and it ranges from 6 feet 2 inches, probably representing only the upper split of the bed, to 28 feet 10 inches, including several partings. The thickest bench of coal devoid of partings is 11 feet 8 inches at locality 793 in the $\mathrm{SW} 1 / 4 \mathrm{NE} 1 / 4$, sec. 5 .

No. 7 coal bed.-A coal bed about 30 feet below the No. 6 bed, herein called the No. 7 coal bed, is exposed at three places in the $\mathrm{N} 1 / 2$ sec. 33 on the divide between the Powder River and Bay Horse Creek. It is 7 feet thick and has no partings at locality 756. At the other two localities, it contains a parting of shale ranging in thickness from 3 to 6 inches.

No. 8 coal bed.-This bed, which is about 80 feet below the No. 6 bed, is exposed near the center of sec. 5 , in the $\mathrm{S} 1 / 2 \mathrm{~N} 1 / 2$ sec. 19 , and in the NW1/4, sec. 30 .

No. 8 a coal bed.-A thin coal bed about 45 feet below the No. 8 bed was mapped a short distance in the valley of Pinto Creek. At locality 791 in the SW1/4 sec. 5 , the bed consists of coal 2 feet 7 inches thick and thin partings.

Cache (No. 9 or No. 8-9) coal bed.-The next thick bed of coal below the No. 8 bed in the northwesternmost part of the township is the Cache, or No. 9 bed. Nos. 8 and 9 beds coalesce at locality 773 near the west line of the NW1/4 NW1/4 sec. 20 , and they are mapped as the No. 8 bed southwest of this locality. On the southeast side of the Powder River, however, the coal bed at this horizon is the Cache, or No. 8-9 bed. The coal bed is thick but contains several partings of shale.

Nos. $9 a, 9 b$, and $9 c$ coal beds.-Three coal beds, designated herein "9a," " $9 \mathrm{~b}$," and "9c," underlie the Cache bed at depths of 75,125 , and 160 feet, respectively. The thickness of No. 9a bed was measured at 10 localities, No. $9 \mathrm{~b}$ at three localities, and No. $9 \mathrm{c}$ at six localities.

\section{T. 8 S., R. 49 E.}

(pl. 6)

The Powder River flows northeastward in a broad flood plain across the northwesternmost part of T. 8 S., R. 49 E. Three Bar and Bay Horse Creeks, tributaries of the Powder River, flow intermittently northwestward across the township. Both creeks have broad grass-covered treeless valleys and gently inclined slopes which end abruptly on the steep slopes of the rugged ridges that 
occupy the interstream areas. The lower parts of the interstream areas are characterized by grass-covered hills and a few patches of pine trees; the higher hills and ridges have large areas of barren rock cliffs and steep slopes capped by thick zones of red clinker. Pine trees are more numerous on the high hills, particularly on the areas underlain by clinker. The relief between the valley bottoms and the crests of the divide is about 300 feet, but on the highest ridges the relief is about twice that. A stratigraphic sequence about 750 feet thick consisting of sandstone, shale, and coal beds of the middle and lower parts of the Tongue River Member of the Fort Union Formation crops out in the township. The uppermost 300 feet of the member is absent owing to erosion, and the lowermost 350 feet of the member is in the subsurface.

The massive sandstone below the Cache (No. 8-9) coal bed is particularly conspicuous where it forms prominent light-tan barren cliffs and hummocks near the quarter corner between secs. 5 and 6 at the southeast margin of the Powder River bottomland. Also, a high conical hill in the SE1/4, sec. 4, capped by the clinker of the Cook (?) (No. 4) coal bed that has a lone pine tree on its edge, is a conspicuous feature of the landscape. The hill can easily be identified from places many miles away on either side of the Powder River.

The rocks dip slightly south of west about 50 feet per mile, according to data obtained from logs of wells drilled for oil and gas. A westerly dip is observed in the rocks exposed along the margins of the valleys of Three Bar and Bay Horse Creeks.

Anderson (No. 1) coal bed.-The crests of the divides in secs. $30,31,26$, and 35 contain a thick clinker that is believed to have been formed by the natural burning of the Anderson coal bed.

Dietz (No. 2) coal bed.-The Dietz coal bed, which lies from 60 to 100 feet below the Anderson coal bed, was observed only in secs. 26 and 35 high on the divide between Three Bar and Bay Horse Creeks. It is 4 feet 6 inches and 5 feet 8 inches thick at localities 691 and 692 , respectively.

Canyon (No. 3) coal bed.-The Canyon coal bed, which ranges from 45 to 60 feet below the Dietz bed, is present on the divide between Buffalo and Three Bar Creeks in the southwestern part of the township and on the divide between Three Bar and Bay Horse Creeks in the southeastern part of the township. Its thickness was not measured in the southwestern area, but it is probably thick because the bed is thick where measured in the area adjacent to 
this township to the south. In the southeastern area the thickness ranges from 6 feet 4 inches to 11 feet 2 inches at the three localities where the bed was measured.

Cook (No. 4) coal bed.-The Cook coal bed, lying about 110 feet below the Canyon bed, contains many partings of shale. It was mapped in the southern part of the township, except near the southeastern corner where it is less than 2 feet thick. The thickness was measured at four localities where it ranges from 2 feet 7 inches to 9 feet 9 inches, including several partings.

No. 5 coal bed.-This bed ranges in depth from 85 to 120 feet below the Cook bed. Its thickness ranges from 5 feet 2 inches to 14 feet 2 inches, including a shale parting 1 foot 8 inches thick, at the eight localities where it was measured. The localities where measurements of the bed's thickness were made are widely separated but are mostly in the southern part of the township.

Local coal bed.-A thin coal bed 40 feet below the No. 5 coal bed was measured at locality 717 in the SE $1 / 4$, sec. 16 . Here it is composed of interbedded thin layers of shale and coal and is of little value; for this reason, it is not included in the estimated reserves of coal shown in table 3 .

No. 6 coal bed.-A coal bed lying about 60 feet below the No. 5 bed is tentatively identified as the No. 6 bed. Its thickness varies greatly, ranging from 4 feet to 17 feet 7 inches, where its base is concealed. The lower bench of the bed is designated "No. 6 split" in table 3.

No. 7 coal bed.-A coal bed lying about 40 feet below the No. 6 bed is exposed at many localities. It is tentatively designated as the No. 7 coal bed. Its thickness ranges from 2 feet 1 inch to 6 feet 2 inches at the 14 localities where it was measured.

Nos. 8 and 8 a coal beds.-The higher of two local coal beds, No. 8 coal bed, 155-175 feet below the No. 5 bed, together with its companion No. 8a, 15-20 feet lower, is prominently exposed on the lower slopes of the bare ridges and spurs above the valley bottoms throughout the northwest quarter of the township as far east as Bay Horse Creek. No. 8 coal bed was measured at 12 localities where its thickness ranges from 2 feet 2 inches to 4 feet 9 inches. The lower bed, No. 8a, was measured at nine localities; it ranges in thickness from 2 feet 8 inches to 4 feet 11 inches. Both beds appear to thin northward and are not mapped beyond the boundary of this township. 
Cache (No. 8-9) coal bed.-The Cache (No. 8-9) coal bed, which is about 250 feet below the No. 5 bed, underlies most of the township. The coal crops out low in the slopes in the northwestern part of the township. In that area, the clinker formed by the natural burning of the coal along its outcrop is a conspicuous red band. The coal is unburned at five localities in secs. 3, 4, 7, and 8, where its thickness, including several partings, ranges from 10 feet $1 / 2$ inch to 13 feet 7 inches. A bed of shale 2-3 feet above the base of the coal bed ranges in thickness from 3 inches to 4 feet 2 inches and appears to increase in thickness southwestward; the other partings are only 1-3 inches thick.

$$
\text { T. } 9 \underset{\text { S., R. }}{\text { (pl. 6) }} 49 \text { E. }
$$

Three Bar and Buffalo Creeks, tributaries of the Powder River, flow intermittently northwestward across T. 9 S., R. 49 E. The valley of Three Bar Creek has rolling gently inclined grass-covered treeless slopes, and it is more than 2 miles wide in the central and northern parts of the township. The valley of Buffalo Creek in the southwestern part of the township is similar but narrower. The gentle slopes of the valleys merge abruptly with the rugged intricately dissected hills and ridges that occupy the interstream highlands. In the highlands large parts of the slopes are barren, rocky, and steep and are characterized by thick red bands of clinker, light-gray bands of sandstone, and dull-gray bands of shale. A thick clinker caps most of the ridges and isolated hills. In general the hills support a patchy growth of pine trees, but the areas underlain by clinker support a particularly abundant stand. The divides rise generally about 300 feet above the valley bottoms, and some ridges and mesas are as much as 600 feet above the bottoms.

The exposed rocks consist of about 600 feet of interbedded lightyellow-gray sandstone, gray shale, and coal of the Tongue River Member of the Fort Union Formation. It is estimated that about 200 feet of the uppermost part of the Tongue River Member is missing owing to erosion and that the lowermost 300 feet of the member is present in the subsurface. Outcrops of coal beds and the clinker are confined chiefly to the higher parts of the divides. The rocks dip westward at about $50^{\prime}$ feet per mile, according to data obtained from logs of wells drilled for oil and gas.

Anderson (No. 1) coal bed.-A discontinuous band of clinker 
on the high ridge in secs. 30 and 31 and small patches of clinker on buttes on the divide between Three Bar and Buffalo Creeks are tentatively correlated with the Anderson coal bed. The rocks back from the outcrop of the clinker in parts of secs. 30 and 31 appear to be unbaked, a condition indicating the presence of unburned Anderson coal; no outcrops of coal, however, were observed.

Dietz (No. 2) coal bed.-A conspicuous clinker, believed to be a result of the burning of the Dietz coal bed and lying 40-50 feet below the Anderson bed, is present high on the divide in the southwestern part of the township. The thickness of the coal bed is from 15 feet to as much as 24 feet 7 inches, as indicated by measurements at localities 658,637 , and 638 in secs. 30 and 31 . The coal is probably unburned in an irregularly shaped area on the divide in these sections.

Canyon (No. 3) coal bed.-The Canyon coal bed is about 60 feet below the Dietz bed. The clinker formed by the natural burning of the coal caps high ridges in the southwestern, southeastern, east-central, and northeastern parts of the township. The bed varies widely in thickness at the 11 places where it was measured. For example, its thickness is 4 feet 5 inches at locality 661 in the SW $1 / 4$ sec. 21 and is 26 feet 11 inches at locality 647 in the SE1/4 sec. 25.

Cook (No. 4) coal bed.-A coal bed 90-130 feet below the Canyon bed is present in parts of this township. It is correlated with the Cook (No. 4) coal bed of the adjacent townships to the west and north. The bed was mapped in the northeastern part of the township on the divide between Three Bar and Bay Horse Creeks, in the western part of the township on the divide between Three Bar and Buffalo Creeks, and in the southwestern part of the township on the divide between Buffalo and Dry Creeks. The thickness of the bed was measured at nine places where it ranges from 3 feet 1 inch to 3 feet 10 inches.

No. $4 a$ (local) coal bed.-The outcrop of a local thin coal bed about 80 feet below the Cook bed, and herein referred to as No. 4a, was mapped for a distance of about three-fourths of a mile in the $\mathrm{N} 1 / 2$ sec. 33 and the $\mathrm{S} 1 / 2$ sec. 28 in the upper drainage of Buffalo Creek. It is 2 feet 4 inches thick at locality 643 in the N1/2 sec. 33 . It was not included in table 3 .

No. 5 coal bed.-A thick coal bed, herein designated the No. 5 bed and lying from 80 to 135 feet below the Cook bed, is widespread throughout the higher parts of the township. Its thickness, 
which was measured at 19 localities, ranges from 7 to 9 feet in the northwestern part of the township and generally from 8 to 10 feet in the southeastern part.

No. 6 coal bed.-A coal bed lying 70 feet below the No. 5 coal bed and herein designated No. 6, was mapped locally in secs. 1, 2, $4,5,8$, and 9 and northward into the adjacent township. It was measured at four places in the township where it is more than 2 feet thick; it thins southward, however, from these localities.

Cache (No. 8-9) coal bed.-Table 3 shows reserves for this bed, based on measurements made in adjacent areas; the bed is at shallow depth.

\section{T. 5 S., R. 50 E., PARTIAL TOWNSHIP}

Only that southeastern part of T. 5 S., R. 50 E., lying southeast of the Powder River is in the mapped area; sec. 36 and parts of secs. 25 and 35 are included. This area is occupied by alluvium of the broad flood plain of the Powder River. The riverbed is about 15 feet below the flood plain. The alluvium overlies the soft beds of the lower member of the Fort Union Formation. This member contains some thin lenticular coal beds, but none is known to be in this part of the township. It is reported, however, that a water well about one-fourth mile south of the SW1/4 SW1/4 sec. 36 penetrated a 2-foot-thick coal bed at a depth of 598 feet and a 3-footthick bed at a depth of 615 feet.

\section{T. 6 S., R. 50 E.}

(fig. 3)

The Powder River flows northeastward across T. 6 S., R. 50 E., from sec. 32 to sec. 1. Only that part of the township lying southeast of the Powder River is included in the mapped area. Except for the river flood plain, the area is characterized by grass-covered treeless gentle slopes. Alluvium occupies the flood plain, which ranges in width from one-fourth to 1 mile on the southeast side of the river and is fertile farmland. The river has cut a meandering course about 15 feet below the flood-plain surface. The broad Baking Powder Creek valley trends northwest across the area. Clinker caps hills and ridges in secs. 34 and 35 on the northern margin of a highly dissected plateau that lies south of this township. Here the surface rises steeply to levels that are 300-400 feet above the lowland near the Powder River. The red clinker zone of the No. 8-9 coal bed is conspicuous on the top of the lower hills 


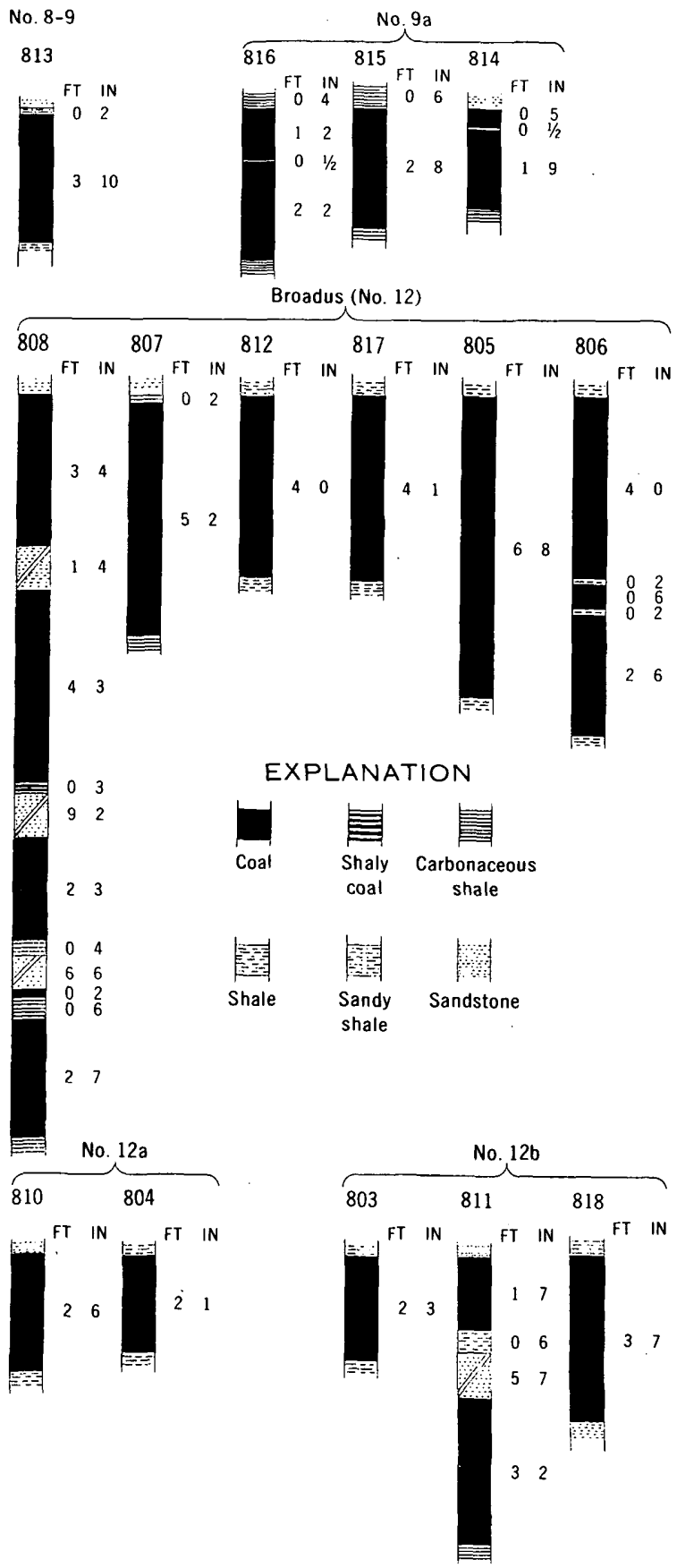

FigURE 3.-Graphic sections of coal beds in T. 6 S., R. 50 E., Moorhead coal field, Montana. 
and in the lower slopes of the high hills and ridges. The clinker of the Broadus coal is conspicuous on ridge prongs in secs. 13 and 24.

Except for the flood plain along the Powder River, the surface of this township is occupied by the lower part of the Tongue River Member of the Fort Union Formation. The contact of the Tongue River with the lower member of the Fort Union is at shallow depth along the Powder River; it passes below the surface of the alluvium only about a mile northeast of the SE. cor. sec. 12. A total thickness of slightly more than 700 feet of the Tongue River Member is present in the area; only the lowermost 300 feet of the rocks, however, is present in most of it. The rocks consist of interbedded light-gray shale, sandy shale, light-yellow-gray sandstone and siltstone, and some coal. In general, the lower part of the Tongue River Member contains a greater quantity of shale than the middle and the upper parts. Accordingly, the surface is not so rugged as that formed on some of the younger rocks of the member.

The rocks dip westward about 50 feet per mile, according to data obtained from logs of wells drilled for oil and gas. The attitude is evident in the exposed rocks in parts of the area.

Cook (No. 4) and No. 5 coal beds and a local bed above the Cook bed.-Two clinker beds a little more than 100 feet apart occupy the high ridge in sec. 35 . These are tentatively identified as the clinker of the Cook and the No. 5 coal beds. A very small patch of clinker of a local coal bed that is stratigraphically above the Cook bed caps the hill in the SW1/4,SW1/4 sec. 35 . Possibly some unburned coal remains in the No. 5 bed, but the Cook bed and the local bed above it have probably burned completely.

No. 8-9 coal bed.-The clinker of the No. 8-9 coal bed, which lies nearly 200 feet below the No. 5 bed, crops out in the slopes of the high ridges in secs. 34 and 35 , and the coal bed extends into secs. 26 and 27 . The thickness of the coal was measured only at locality 813 in the SE1/4 sec. 27, where it is 3 feet 10 inches thick.

No. 9 a coal bed.-A coal bed 100 feet below the No. 8-9 bed is designated "9a." It is present low in the ridge slopes in secs. $25-28$ and 33-36, where it is unburned. The thickness of the coal ranges from 2 feet 2 inches to 3 feet $41 / 2$ inches at localities 814, 815 , and 816 in secs. 27,33 , and 34 , respectively.

Broadus (No. 12) coal bed.-The Broadus coal bed, which is about 135 feet below the No. 9a bed, crops out extensively a short distance above the alluvium of the Powder River valley. It extends 
a long way up the Baking Powder valley, probably across secs. 23, 24 , and into 25 , but does not crop out through most of the valley. Its thickness ranges from 4 feet to 8 feet 11 inches at six localities in secs. $13,23,24,28$, and 33 . A lower bench 2 feet 3 inches thick is 9 feet 5 inches below the 8-foot- 11-inch-thick upper bench at locality 808 in the SW $1 / 4$ sec. 23.

Nos. $12 a$ and $12 b$ coal beds.-Two thin beds of coal 32 and 50 feet, respectively, below the Broadus (No. 12) bed crop out a short distance above the alluvium of the Powder River valley. They are herein designated " $12 a$ " and " $12 b . "$ No. $12 a$ bed is 2 feet 1 inch and 2 feet 6 inches thick at localities 804 and 810, respectively, and No. 12b ranges in thickness from 2 feet 3 inches to 3 feet 7 inches at three localities.

T. 7 S., R. 50 E.

(pl. 6)

Except for the Powder River bottom lands in the northwesternmost part and the grass-covered valley of Buttermilk Creek in the southwestern part, T. 7 S., R. 50 E., is generally fairly rugged hill country formed by an intricately dissected plateau. Thick clinker caps ridges and forms prominent benches in steep slopes, and pine trees grow on the clinker surfaces. Butte Creek, a tributary of the Powder River, flows intermittently northwestward across the township in a relatively wide grass-covered valley flanked by hills of clinker. The orange-red clinker of the No. 8-9 coal bed and the 50 -foot-thick light-gray sandstone below it form conspicuous bands on the northern side of Butte Creek valley; these bands extend from sec. 4 southeastward for as much as 3 miles. Light-gray bare sandstone buttes, the Turret Buttes, in sec. 5 southwest of Butte Creek are formed by the thick sandstone underlying the No. 8-9 coal bed. Higher ridges in the township are capped by the clinker of the Cook coal bed and the No. 5 coal bed.

Except for the alluvium along the Powder River and elsewhere along some tributary streams, the exposed rocks are in the Tongue River Member of the Fort Union Formation. The sequence of beds exposed has a total thickness of about 500 feet; it consists of lightbuff to yellow or white massive beds of sandstone, sandy shale, small amounts of shale, and 8 to 10 beds of coal. Stratigraphic sections measured in T. 7 S., R. 51 E., show that at least the lowermost 100 feet of the Tongue River Member, which contains several coal beds, underlies the exposed beds in T. 7 S., R. 50 E. The rocks dip westward about 50 feet per mile, according to data obtained from logs of wells drilled in the region for oil and gas. 
Cook (No. 4) coal bed.-A thick clinker formed by the natural burning of the Cook coal bed caps the high ridges in the southern, eastern, and central parts of the township. The unbaked condition of the rocks overlying the coal for about one-fourth mile back from the outcrop indicates that the coal is unburned in the middle parts of many of the broader ridges, such as those in sec. $36,21,28,32$, and 13, and locally elsewhere. An incomplete thickness of the bed was measured at locality $829 \mathrm{a}$ in the $\mathrm{SE} 1 / 4$, sec. 13 , where it is $11+$ feet.

No. 5 coal bed.-A sequence of interbedded light-yellow-gray sandstone and shale occupies the interval of 100 feet between the Cook and the No. 5 coal beds. The clinker of the No. 5 bed forms a red band high in the steep-sided ridges about 100 feet below the ridge tops. The coal, throughout most of the area, however, has not burned far back from the outcrop because of the thick overburden. Measurements at seven localities widely distributed in the eastern and southern parts of the township indicate that the main bench of coal ranges in thickness from 11 feet to 18 feet 10 inches. At most localities, a bench of coal ranging in thickness from 2 to 5 feet is present about 12 feet above the main bench.

No. 5 a coal bed.-A coal bed, 2 feet 2 inches to 2 feet 8 inches thick, lying 40 feet below the No. 5 bed, was mapped locally near the center of sec. 26 and in the $\mathrm{E} 1 / 2$ sec. 12 . The extent of this thin bed is so limited that reserves of coal are not shown in table 3 .

No. 6 coal bed.-The outcrop of the No. 6 coal bed projects into the SW $1 / 4$ sec. 32 from an extensive outcrop in the township adjacent on the south. Reserves of coal in this bed in 240 acres in $T$. 7 S., R. 50 E., are shown in table 3.

No. 8-9 coal bed.-The outcrop of this coal bed, which lies 170 feet below the No. 5 bed, is widespread in this township. It has been burned at most places along its outcrop, and its bright orangered clinker forms a conspicuous band above a light-gray band formed by a massive sandstone about 50 feet thick. The thickness of the coal bed ranges from 8 feet to 24 feet at the four widely separated localities in secs. $3,13,29$, and 31 , where it was measured.

Nos. $9 a, 9 b$, and $9 c$ coal beds.-Three lenticular beds of coal crop out in the low slopes beneath the 50-thick sandstone that underlies No. 8-9 coal bed and clinker. They lie at intervals of 110,160 , and 180 feet, respectively, below the No. 8-9 coal bed. The No. 9a bed appears to be the most persistent of the three. Its thickness ranges 
from 5 to 8 feet at six localities in the northern part of the township where it was measured, and it consists of shaly coal 5 feet thick at locality 842 in the SE1/4 sec. 35 . The No. $9 \mathrm{~b}$ coal bed is only slightly thicker than 2 feet at the four localities in secs. 5, 15, and 18 where it was measured, and it consists of shaly coal near the NW. cor. sec. 15. The No. 9c coal bed is from 2 feet 4 inches to 3 feet 2 inches thick at three localities in secs. 3, 5, and 15 .

No. 12 coal bed.-Reserves of the No. 12 bed, based on data shown for T. 6 S., R. 50 E., are shown in table 3.

$$
\text { T. } 8 \text { S., R. } 50 \text { E. }
$$

(pl. 6)

The surface of T. 8 S., R. 50 E., is characterized by wide gently sloping treeless valleys between clinker-capped partly forested hills. The broad valley of Bay Horse Creek trends northwestward across the southwestern part of the township. Butte Creek flows intermittently northwestward toward the Powder River across the northeastern part of the township. The clinker of the No. 8-9 coal bed forms a red bordering ledge along the upper slopes of Butte Creek valley. Clinker of the higher coals-No. 5, Cook (No. 4), and Canyon (No. 3) -are prominent in the high hills in the southern part of the township.

A stratigraphic sequence at least 500 feet thick, which consists of light-yellow to buff sandstone, gray shale, and coal beds of the middle part of the Tongue River Member of the Fort Union Formation, crops out in the township. The oldest part of the member is present on Butte Creek in the northeastern part of the township. Here the No. 8-9 coal bed and rocks underlying it crop out.

The exposed rocks appear to dip westward at a low angle, as observed on the outcrops. Moreover, data obtained from logs of wells drilled in the rigion for oil and gas indicate that the rocks dip westward about 50 feet per mile.

At least six beds of coal of minable thickness crop out in the township. Thickness of coal in a single bed as measured on the outcrops ranges from 2 feet to 18 feet 8 inches. The Cook bed and the No. 5 bed seem to retain their large thickness throughout the township more than the others.

Canyon (No. 3) coal bed.-A coal bed and associated clinker that occupies small areas on the crest of the divide in the southcentral part of the township between Bay Horse and Butte Creeks is tentatively correlated with the Canyon bed. A coal bed 3 feet 
6 inches thick is present at this position at locality 863 in the NW $1 / 4$ sec. 27 , and a bed 2 feet 4 inches thick is at locality 878 in the NE $1 / 4$ sec. 33 .

Cook (No. 4) coal bed.-The base of the Cook coal bed is 110 feet below the Canyon bed. The outcrop and clinker of this bed is widespread high on the divide between Bay Horse and Butte Creeks. The thickness of the coal bed was measured at seven localities where it ranges from 9 feet 2 inches to 15 feet 6 inches of solid coal. In addition, the bed is 16 feet 8 inches thick at locality 855 in the W1/2 sec. 18, including two partings of shale 2 feet 5 inches and 5 feet 3 inches thick. The lack of alteration of the rocks directly back of the clinker outcrop along the divide indicates that large irregularly shaped areas of thick coal are present a short distance below the crest of the divide.

No. 5 coal bed.-The base of the No. 5 coal bed is 110 feet below the Cook bed. It crops out high on the slopes of the highest ridges and hills in the township. Its thickness was measured at 12 localities where it ranges from 3 feet 5 inches to 15 feet 6 inches.

No. 5 a coal bed.-A coal bed herein called No. $5 \mathrm{a}, 45$ feet below the No. 5 bed, was mapped locally in the NE1/4, sec. 12 and in secs. $14,15,21,23,29$, and 30 . The thickness of the bed is varied, and it contains partings of shale and shaly coal at some places. It is thickest at locality 850 in the NE1/4 sec. 12 where it is 7 feet 8 inches thick. Elsewhere it is much thinner.

No. 6 coal bed.-A coal bed 135 feet below the No. 5 bed is herein designated the "No. 6." Its outcrop was mapped only in the southwestern and northwestern parts of the township, where its thickness was measured at seven localities. Its thickness ranges from 5 feet 11 inches to 15 feet 7 inches, and except at locality 847 in the NW1/4 sec. 8 , the bed contains several partings of shale. At locality 847 the bed consists of two benches of coal each about 7 feet thick that are separated by a parting of shale 5 inches thick.

No. 8-9 coal bed.-The outcrop of the orange-red clinker of the No. 8-9 coal bed is widespread in Butte Creek valley in the eastern part of the township, and the appearance of the rocks overlying the coal bed indicates that, except in secs. 2 and 3 , the coal has been burned only a short distance back from the outcrop. Its thickness, measured only at the abandoned G. Russell's mine, locality 862 in the $\mathrm{S} 1 / 2$ sec. 25 , is 18 feet 8 inches.

No. 9 a coal bed.-A thin bed of coal about 30 feet below the base of the No. 8-9 clinker is 2 feet 10 inches thick at locality 844 in 
the SW1/4, sec. 2 and 2 feet 6 inches thick at locality 849 in the SW $1 / 4$ sec. 12.

T. 9 S., R. 50 E.

(pl. 6)

The valley of Bay Horse Creek is the dominant surface feature in T. 9 S., R. 50 E.; it trends northwestward across the township. The valley is a broad expanse of rolling grassland from 1 to 2 miles wide; some of it is dry-farmed. Relatively rugged, clinkercapped, intricately dissected ridges border the valley. Pine trees are fairly abundant on the upland, growing chiefly on the clinker. Large barren areas on steep slopes expose thick red clinker and gray shale interbedded with some light-gray to light-tan sandstone. The terrain is less rugged in the eastern part of the township, and broad rolling valleys are predominant.

The entire township is underlain by rocks of the middle part of the Tongue River Member of the Fort Union Formation. The sequence consists of about 600 feet of interbedded thick light-yellow to light-buff sandstone, sandy shale, and coal.

Data obtained from logs of wells drilled for oil and gas show that the rocks dip westward about 50 feet per mile.

Anderson (No. 1) or Dietz (No. 2) clinker.-A few small patches of clinker cap buttes on the crests of the divides in secs. 31,29 , and 33 . The clinker is tentatively identified as that of the Anderson coal bed, although it may be the clinker of the Dietz coal bed which elsewhere is 50-75 feet below the Anderson. The Anderson coal bed is commonly about 140 feet above the base of the Canyon coal bed.

Canyon (No. 3) coal bed.-The clinker of the Canyon coal bed is widespread on the divides in the western and southwestern parts of the township. The unaltered rocks a short distance back from the outcrop of clinker indicate that unburned coal in the Canyon bed is present in the central parts of the generally flattopped ridges. The thickness of the coal bed ranges from 10 feet 9 inches, including a parting 8 inches thick, to 19 feet 8 inches of solid coal at the three localities where it was measured.

Cook (No. 4) coal bed.-The Cook coal bed, which is 120 feet below the Canyon bed, crops out in the northeastern part of the township. The evidence in the field is not sufficient to show positively whether the clinker capping the long narrow ridge that trends from the SW1/4 sec. 34 northwestward through the SW1/4 
sec. 19 is at the position of the Canyon bed (as shown on the map) or of the Cook coal bed.

No. 5 coal bed.-The base of the No. 5 coal bed is about 110 feet below the Cook bed in this township. Although the coal has been burned at the outcrop, alteration does not extend far back from the outcrop because the clinker outcrop is in steep slopes. The thickness of the No. 5 coal bed was measured at 14 localities.

No. 5 a coal bed.-A thin coal bed about 45 feet below the No. 5 bed was mapped in the NE1/4 sec. 6 . It contains two thin benches of coal separated by shale and shaly coal at locality 884 in the NE $1 / 4$ sec. 6.

Local (No. 6?) coal bed.-The outcrop of a thin coal bed 125 feet below No. 5 bed was mapped in the southeastern part of the township.

No. 8-9 coal bed.-The outcrop of the No. 8-9 coal bed, 190 feet below the No. 5 bed, was mapped in the upper part of the valley of Bowers Creek in the southeastern part of the township. The thicknesses of the bed are 8 feet 2 inches and 7 feet 5 inches, including a parting 1 to 2 inches thick, at localities 893 and 894 , respectively, in sec. 25 . Only 3 feet of the bed is exposed at locality 892 in the SW1/4 sec. 24.

\section{T. 4 S., R. 51 E., PARTIAL TOWNSHIP}

Only that part of T. 4 S., R. 51 E., lying southeast of the Powder River, an area of less than 3 square miles, is included in the coal field. Here the alluvial flood plain of the Powder River is from one-fourth to a little more than a mile wide and occupies most of the area. The river flows northeastward in a meandering channel that is cut about 15 feet below the flood plain. The area southeast of the flood plain is occupied by the lower member of the Fort Union Formation, which is composed of interbedded dark- and light-gray shale and lighter gray to tan siltstone. Although the member generally contains lenticular beds of coal, none was seen in this area.

\section{T. 5 S., R. 51 E., PARTIAL TOWNSHIP}

(fig. 4)

The part of T. 5 S., R. 51 E., that is southeast of the Powder River, about three-fourths of the township, is in the mapped area. A belt alluvium which ranges in width from zero to three-fourths of a mile borders the Powder River. The river has cut a meander- 
ing course northeastward, and its channel lies about 15 feet below the flood plain. The rest of the township consists of rolling treeless grassland. Only a few small patches of bare rock crop out in the township, and a few buttes which are capped by lenses of brown sandstone rise above the general level. The river bottom land is irrigated rich farmland and a considerable part of the rolling upland is dry farmland.
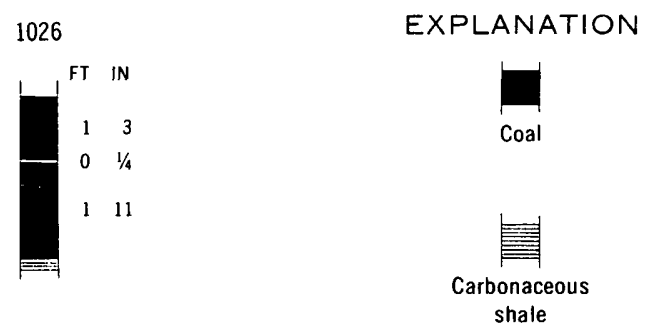

Figure 4.-Graphic section of local coal bed in T. 5 S., R. 51 E., Moorhead coal field, Montana.

Except for the belt of alluvium along the Powder River, the lower member of the Fort Union Formation occupies the surface cf the township. The member consists of interbedded gray to darkgray shale and silty shale and contains some beds of darkbrownish-gray carbonaceous shale and grayish-tan sandstone and a few lenticular beds of brown sandstone.

Although the general attitude of the rocks cannot be determined from the exposed rocks because exposures are so few, the regional dip appears to be westward about 35 feet per mile, as determined from the logs of wells drilled in the region for oil and gas.

Local coal bed.-Only one thin lens of coal was mapped in the township. Its thickness is 3 feet 2 inches at locality 1026 at the south line of the SW1/4, sec. 28.

$$
\begin{aligned}
& \text { T. 6. S., R } 51 \text { E. } \\
& \text { (fig. 5) }
\end{aligned}
$$

Most of T. 6 S., R. 51 E., is drained by northwestward-flowing Baking Powder, First, Second, and Third Creeks, which are intermittent tributaries of the Powder River. The valleys of these tributaries and most of the northern and western parts of the township have a rolling grass-covered treeless surface devoid of 
barren rock outcrops. The slopes of the divide between First and Second Creeks are characterized by barren, banded, light-gray and gray rocks capped by red clinker. The southernmost part of the township contains the margin of a deeply dissected, partly wooded plateau that is at least 300 feet above the rolling grasslands. Here red clinker caps the hills.

The surface rocks in the northern part of the township consist of interbedded dark- and light-gray shale and siltstone and some sandstone of the upper part of the lower member of the Fort Union Formation. The rocks in the rest of the township consist of interbedded light-yellow-gray sandstone, sandy shale, gray shale, and coal of the lower part of the Tongue River Member.

A low-angle westward dip can be observed in the exposed rocks in many places in the township; a dip westward about 65 feet per mile is indicated by data obtained from logs of wells drilled in the region for oil and gas.

No. 5 coal bed.-Clinker of the No. 5 coal bed is exposed in secs. 32 and 33 on the highest part of the divide between Baking Powder and First Creeks. It is possible that some unburned coal is present in the middle part of the ridge in the $\mathrm{S} 1 / 2$ sec. 32 .

No. 8-9 coal bed.-Clinker of the No. 8-9 coal bed caps most of the high ridge in the southern part of the township between Baking Powder and First Creeks. The coal bed is not exposed, and its thickness is unknown, but the lack of alteration of the rocks indicates that coal is present in a relatively large area in the $\mathrm{S} 1 / 2$ sec. 32 and in a small area in the $\mathrm{S} 1 / 2$ sec. 33 .

Local coal beds below the No. 8-9 bed.-A coal bed 3 feet thick including a 4-inch shale parting 7 inches below the top was observed 60 feet below the No. 8-9 clinker at locality 986 in the SW $1 / 4$ SE $1 / 4$ sec. 36

Several thin coal beds were mapped below the No. 8-9 bed in secs. 30 and 31. A local bed 130 feet below the No. 8-9 bed is about 3 feet thick at locality 996 and 4 feet 4 inches thick including 1 foot 7 inches of shaly coal at locality 997 in the SE $1 / 4$ sec. 30 ; a local bed 28 feet lower is 2 feet 2 inches thick at locality 995 , and at locality 994 it consists of shaly coal 2 feet 8 inches thick. It is possible that one of the two coal beds described above, at locality 994 or 995 , is equivalent to the bed at locality 987 (which is mapped as the No. 11 coal bed) in sec. 36 , inasmuch as the distance below the No. 8-9 bed is similar at the two places.

A local coal bed that crops out around the lower part of a 

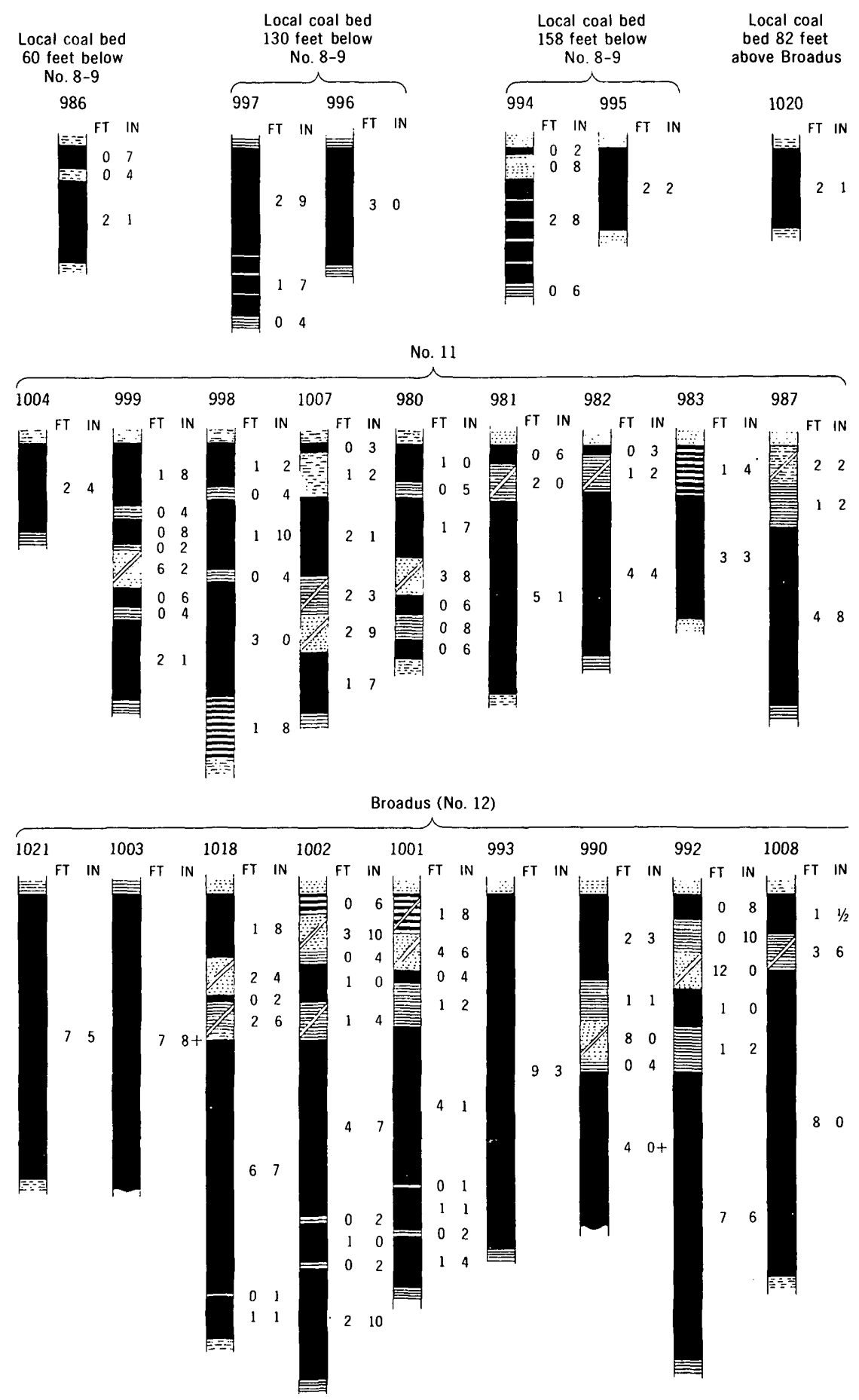
COAL IN T. 6 S., R. 51 E.
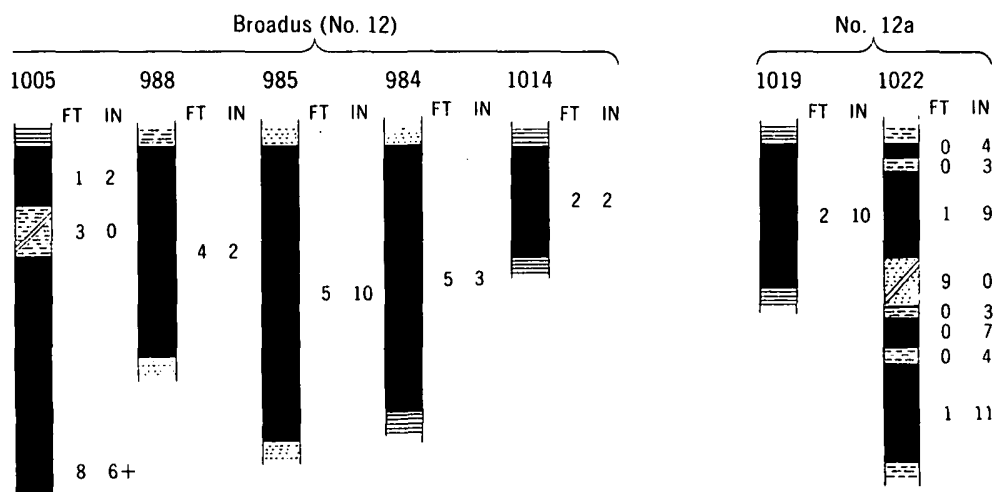

No. $12 b$

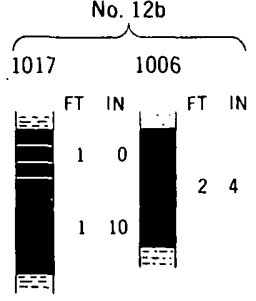

Olsen or Contact (No. 13)
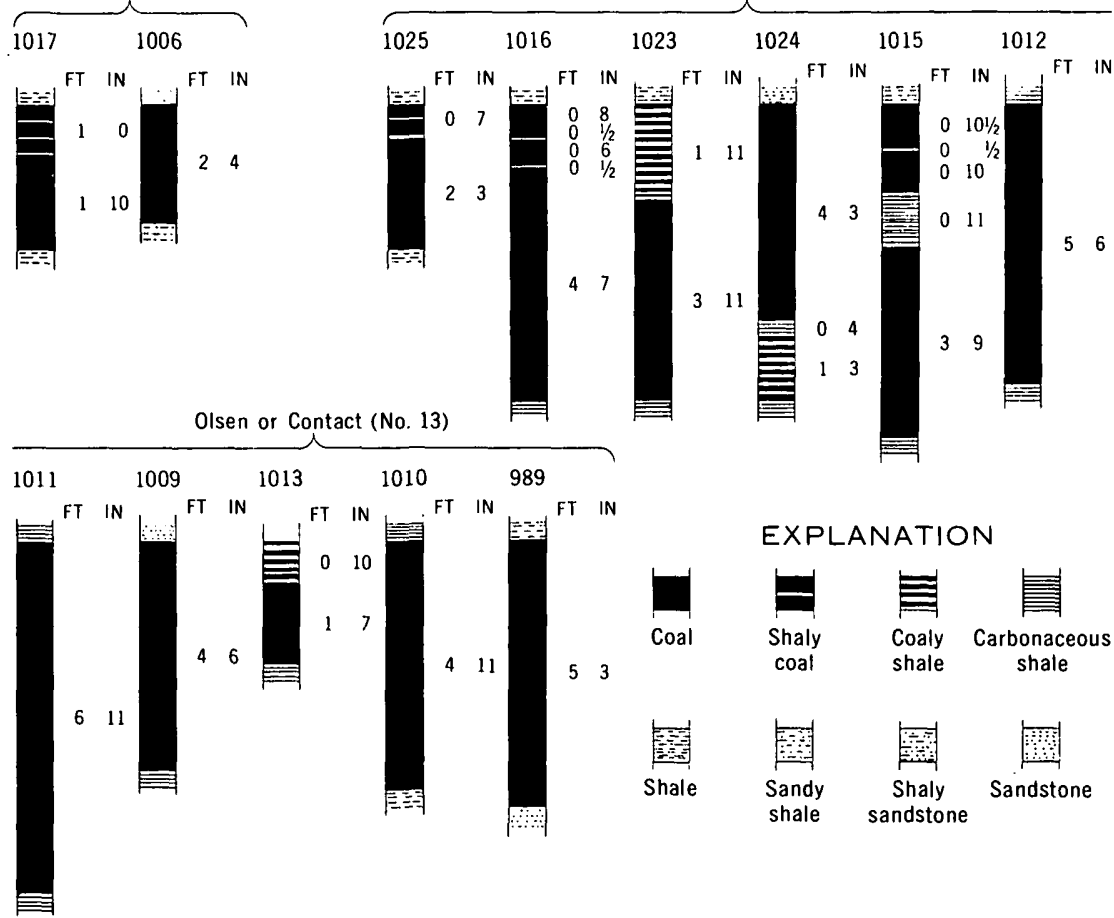

EXPLANATION
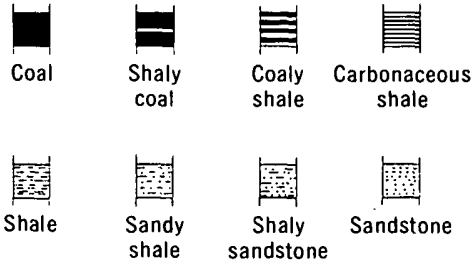

Shaly Sandstone sandstone

Figure 5.-Graphic sections of coal beds in T. 6 S., R. 51 E., Moorhead coal field, Montana. 
sandstone ridge in the SW $1 / 4$, sec. 18 is 82 feet above the base of the Broadus coal bed. It is 2 feet 1 inch thick at locality 1020. A coal bed 1 foot 4 inches thick and 271/2 feet below this local bed is not shown on the map. Reserves were not calculated for these thin beds of local extent.

No. 11 coal bed.-A coal bed $60-80$ feet above the base of the Broadus bed is designated the No. 11 bed. It crops out in secs. 30 and 31 where, at localities 980,998 , and 999, it consists of several thin benches of coal. Its thickness ranges from 3 feet 3 inches to 5 feet 1 inch at the localities in secs. 33, 34, and 36 at which the bed was measured.

Broadus (No. 12) coal bed.-The Broadus coal bed, about 100 feet above the base of the Tongue River Member, is widespread in the township. The thickness of the main bench of coal ranges from 4 feet 2 inches to 9 feet 3 inches at 13 of the 14 localities the bed was measured.

Nos. $12 a$ and $12 b$ coal beds.-A local coal bed, 38 feet below the Broadus bed, is designated herein as "No. 12a." It consists of three thin benches of coal at locality 1022 in the SW1/4 sec. 8 and a single bed 2 feet 10 inches thick at locality 1019 in the SW1/4 sec. 16. Another thin coal bed, designated "No. 12b" and 60-70 feet below the Broadus bed, is 2 feet 4 inches thick at locality 1006 in the SW $1 / 4$, sec. 22 and 2 feet 10 inches thick, including 1 foot of shaly coal, at locality 1017 in the SW1/4, sec. 15. These two beds are not included in table 3 because they are thin and extremely lenticular.

Olsen or Contact (No. 13) coal bed.-A thin coal bed at the base of the Tongue River Member, called the Olsen bed in this township and the Contact bed in some parts of the coal field, was mapped across the northeastern and northern parts of the township. It passes beneath the alluvium of the Powder River bottom lands in the NE1/4, NE $1 / 4$ sec. 7 . Its thickness was measured at 11 localities, and it is thickest, 6 feet 11 inches, at locality 1011 at the NW. cor. sec. 24.

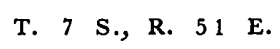

The surface of T. 7 S., R. 51 E., is characterized by intricately dissected margins of a sparsely forested plateau, whose dominant features are steep-sided hills and ridges. Broad bands of red clinker and bands of very light gray sandstone are exposed on the 
steep slopes, and a thick clinker caps the slopes and the flat-topped ridges. The broad valley of Baking Powder Creek, which is an intermittent tributary of the Powder River, trends northwestward across the township and bisects the plateau. Baking Powder valley, the widest of all valleys in the region whose creeks are tributaries of the Powder River, is $11 / 2-2$ miles wide. It has gentle grass-covered slopes, some of which are dry-farmed.

The uppermost part of the lower member and about 950 feet of the basal part of the Tongue River Member of the Fort Union Formation are exposed. The upper part of the lower member consists of interbedded dark- and medium-gray shale, dark- and light-gray siltstone, and some sandstone. The Tongue River Member consists of interbedded light-yellowish-gray sandstone, sandy shale, shale, and coal. Most of the coal beds have burned along their outcrops and have formed thick beds of clinker.

A small angle of dip westward was observed at many places in the township where the rocks are exposed. Moreover, data obtained from logs of wells drilled in the region for oil and gas indicate that the rocks dip westward about 65 feet per mile.

Anderson (No. 1), Dietz (No. 2), and Canyon (No. 3) coal beds. -Erosional remnants of the clinkers formed by the natural burning of the Anderson, Dietz, and Canyon coal beds remain in sec. 19 on the crest of the divide between Baking Powder and Butte Creeks.

Cook (No. 4) coal bed and No. 5 coal bed.-Clinkers formed by the natural burning of the Cook coal bed and the No. 5 coal bed, which are about 100 feet apart stratigraphically, are widespread on the divide in the southwestern part of the township. Moreover, unaltered rocks a short distance back of the clinker indicate unburned coal of the Cook bed and the No. 5 bed in fairly extensive irregularly shaped areas on the divide. The thicknesses of the coal beds are not known, but data from adjacent townships indicate that they are about 11 and 12 feet, respectively.

No. 4 a (local) coal bed.-A coal bed which is 25 feet below the Cook coal bed is 4 feet thick where its top and base are concealed at locality 966 in the $\mathrm{NW} 1 / 4$ sec. 19 . It could not be traced away from this locality and so was not included in table 3.

No. 8-9 coal bed.-The outcrop of the No. 8-9 coal bed, which is about 170 feet below the No. 5 bed, is widespread in this township. The coal has been burned nearly everywhere, but at most 
places the burning has not extended far back from the outcrop. The thickness of the coal ranges from 15 to 25 feet at five of six localities where it was measured.

Local coal beds below No. 8-9 bed.-A local coal bed 11 feet below the No. 8-9 coal bed contains 4 feet of shaly coal at locality 965 in the SE1/4, sec. 20. A local coal bed, which is about 40 feet below the No. 8-9 bed, is from 3 feet to 4 feet 2 inches thick at localities 970 and 963 in secs. 13 and 23 and contains shaly coal 4 feet thick at locality 960 in sec. 23 . Reserves were not shown in table 3 because the beds are extremely local in extent.

No. 9 a coal bed.-This coal bed, about 100 feet below the No. $8-9$ bed, was mapped through secs. $6,7,8$, and 18 . The bed is 5 feet thick $11 / 4$ miles west of the NW. cor. sec. 6 at locality $825 \mathrm{a}$ in T. 7 S., R. 50 E., and the coal pinches out in the SW1/4 sec. 8.

No. 11 coal bed.-A coal bed about 160 feet below the No. 8-9 bed, called No. 11 , is exposed in secs. $1,2,3,13$, and 23 . Its thickness ranges from 6 feet 2 inches to 6 feet 10 inches, including one or two partings at three localities in secs. 1,2, and 3. It consists of shaly coal 3 feet 6 inches thick at locality 962 in sec. 23.

Local coal bed 50 feet above the Broadus coal bed.-A local coal bed, 50 feet above the Broadus bed, is 2 feet 2 inches thick at its exposure at locality 975 in the $\mathrm{SE} 1 / 4$, sec. 1 . Reserves for this thin bed are not shown in table 3.

Broadus (No. 12) coal bed.-The Broadus coal bed, about 240 feet below the No. 8-9 bed, is exposed at a few places in the northeastern part of the township. Its thickness ranges from 2 feet 6 inches to 6 feet 4 inches at the three localities in secs. 1, 2, and 13 where it was measured.

Olsen or Contact (No. 13) coal bed.-The Olsen coal bed, the basal bed of the Tongue River Member, was mapped near the eastern margin of the township. The main bench contains 4 feet of coal, which is overlain by shaly coal 2 feet thick at locality 959 in the $\mathrm{NW}^{1} / \mathbf{4}$, sec. 25.

$$
\text { T. } 8 \text { S., R. } 51 \text { E. }
$$

The surface of T. 8 S., R. 51 E., is characterized by broad grasscovered treeless valleys flanked by an intricately dissected partly wooded plateau and hills capped with the red clinker of the No. 8-9 coal bed. Most of the trees grow on the clinker surface. This clinker surface forms the divide between the Powder and Little Powder Rivers; tributaries of these two rivers head here. The 
main divide has an irregular course northward across the middle of the township.

A stratigraphic sequence about 600 feet thick, chiefly of the Tongue River Member of the Fort Union Formation but including the upper part of the lower member of the Fort Union, constitutes the surface. The upper part of the lower member consists of somber-gray to brownish-gray to gray interbedded siltstone, sandstone, and shale. The Tongue River Member consists of interbedded light-tan to yellow sandstone, sandy shale, shale, and coal. The boundary between the two members is drawn at the base of the Olsen (also called Contact) coal bed.

Data obtained from logs of wells drilled in the region for oil and gas indicate that the rocks dip westward about 75 feet per mile. The exposed rocks have a similar attitude. Moreover, the westward dip is observed in the exposed rocks in parts of the township.

Cook (No. 4) and No. 5 coal beds.-Clinkers of the Cook and the No. 5 coal beds crop out on a few high hills in the northwestern part of the township. Coal appears to be unburned in small areas, and thicknesses of 12 and 13 feet, respectively, are indicated from regional data.

No. 5 a coal bed.-A coal bed about 40 feet below the No. 5 bed crops out in the northwestern part of the township. Its thickness varies; at locality 952 in the NE1/4 sec. 5, its thickness is 2 feet 7 inches, about half of which is shaly coal. It is 5 feet 6 inches thick at locality 950 in the NE1/4, sec. 7 and 6 feet 6 inches at locality 951 in the NE1/4.SE1/4, sec. 6 .

No. 8-9 coal bed.-The outcrop of the No. 8-9 coal bed, which is 150 feet below the No. 5a bed, is widespread, but the coal has burned nearly everywhere along the outcrop. Unburned thick coal is present a short distance back of the outcrop.

Local coal bed.-A local coal bed, 45 feet below the No. 8-9 coal bed, is 2 feet 1 inch thick at locality 940 in the W1/2 sec. 18 . This thin bed is not included in table 3 .

No. $9 a$ coal bed.-A lenticular coal bed, herein referred to as No. $9 \mathrm{a}$, is locally at intervals of 70 feet or more below the No. 8-9 bed. The thickness of the No. 9a bed is slightly more than 2 feet at the four localities in secs. 11,14 , and 22 where it was measured.

Local coal bed.-A coal bed 40 feet below the No. 9a bed is 
exposed at locality 938 in the $\mathrm{NW}^{1 / 4}$ sec. 22 . It is not recorded in table 3.

No. 11 coal bed.-This coal bed, in this township about 110 feet below the No. 8-9 bed, is 2 feet 11 inches thick at locality 957 in the $\mathrm{N} 1 / 2$ sec. 2 and 2 feet 10 inches thick at locality 944 in the NE $1 / 4$ sec. 23.

Broadus (No. 12) coal bed.-The Broadus coal bed is 185 feet below the No. 8-9 bed and about 35 feet above the base of the Tongue River Member. It was mapped continuously in the eastern part of the township from the north boundary southward to sec. 34 , where it pinches out. Its thickness ranges from 2 feet 2 inches to 6 feet 10 inches, including a parting 3 inches thick, at the eight localities where it was measured.

Olsen or Contact (No. 13) coal bed.-The Contact coal bed is at the base of the Tongue River Member. It extends southward entirely across the eastern part of the township. The thickness of the coal ranges from 3 feet 6 inches to 6 feet 3 inches at seven localities. It is thickest at locality 943 in the $\mathrm{SE} 1 / 4, \mathrm{sec} .14$.

$$
\text { T. } 9 \text { S., R. } 51 \text { E. }
$$

(pl. 6)

A rolling treeless grass-covered surface characterizes most of T. 9 S., R. 51 E. In an irregular belt of country about a mile wide at its western margin, however, the surface rises to the highly dissected partly wooded plateau, which is underlain by the Tongue River Member. The basal 100 feet of this member forms the marginal part of the rolling plain that extends from the western margin of the township far to the east. The surface is drained eastward by Bowers Creek and its north fork, intermittent tributaries of the Little Powder River.

The eastern two-thirds of T. 9 S., R. 51 E., is underlain by the lower member of the Fort Union Formation, which consists of somber brownish-gray to gray interbedded siltstone, sandstone, and shale, and a few lenticular thin beds of coal. The rocks dip westward about 75 feet per mile according to data obtained from logs of wells drilled in the region for oil and gas.

Cook (No. 4) and No. 5 coal beds.-Clinkers of the Cook, and the No. 5 coal beds cap a few high buttes near the west margin of the township. The clinker of the Cook bed is limited to a few small areas in secs. 6, 7, and 19. The clinker of the No. 5 bed outlines larger areas, and the lack of alteration of the rocks a short 
distance back from the outcrop suggests that unburned coal of this bed is present in several tracts. The No. 5 coal bed is 22 feet 3 inches thick, including many partings of shale at locality 918 in the NW1/4 sec. 19. Part of the bed was measured at localities 906 and 909 in sec. 31.

Local coal bed.-A local coal bed 64 feet above the No. 5 bed, between the Cook and the No. 5 bed, is 10 feet 3 inches thick, including several partings, in a small area at locality 910 in the $\mathrm{N} 1 / 2$ sec. 31 . The extent of the bed is too small to show in table 3 .

Local coal bed.-A local coal bed about 60 feet above the No. 8-9 bed was mapped for a short distance in secs. 30 and 31 ; it crops out at one place in the SE $1 / 4$ sec. 19. It is 2 feet and 2 feet 2 inches thick at localities 912 in the $\mathrm{NE} 1 / 4$ sec. 31 and 914 in the $\mathrm{SE} 1 / 4$ sec. 30 , respectively. It is 2 feet 11 inches thick at locality 916 in the SE $1 / 4$ sec. 19.

No. 8-9 coal bed.-The most widespread thick clinker in the western part of the township was formed by the natural burning of the No. 8-9 coal bed, which lies 200 feet below the No. 5 bed. The coal thickness ranges from 5 feet 6 inches to 14 feet 10 inches at the 12 localities where it was measured.

Local coal bed.-A local coal bed about 60 feet below the No. 8-9 bed is about 3 feet thick at locality 924 in the SW1/4 sec. 17 and at locality 921 in the NW1/4 sec. 20 . The bed was not traced beyond these two localities.

Olsen or Contact (No.13) coal bed.-The horizon of the Contact coal bed was mapped northward across the western part of the township. The bed ranges in thickness from about 2 to 4 feet at the four localities where it was measured.

\section{T. 4 S., R. 52 E.}

(fig. 6)

That part of T. 4 S., R. 52 E., which lies east of the Powder River is characterized by grass-covered rolling treeless slopes interrupted by small barren patches of somber banded gray and dark-gray shale, brownish-gray carbonaceous shale, a few bands of light-gray siltstone, and a few lenses of irregularly bedded rusty-brown sandstone, each only a few feet thick. A few buttes whose barren slopes are banded rise above the general rolling surface. The flood plain of the Powder River occupies much of the western third of the township; its width east of the river ranges from 0 to 1 mile. The flood plain of the Little Powder 


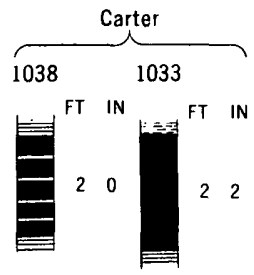

Continued from

above

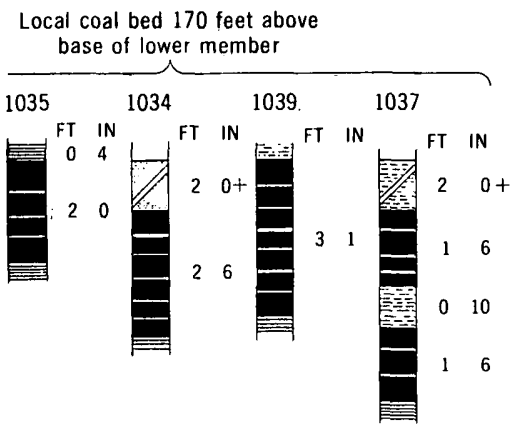

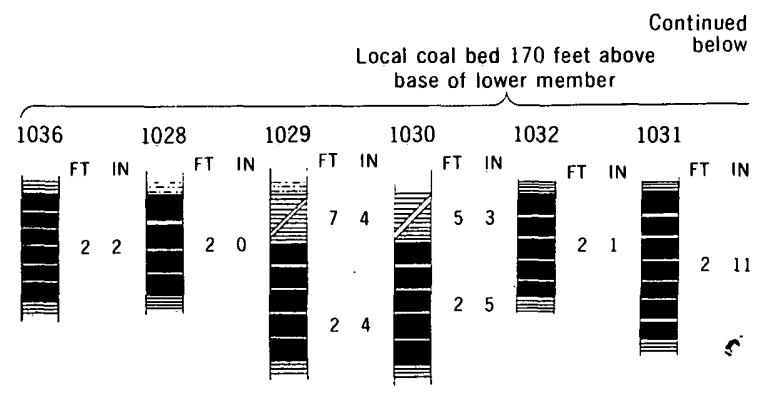

FIGURE 6.-Graphic sections of coal beds in T. 4 S., R. 52 E., Moorhead coal field, Montana.

River, which joins the Powder River in the SW1/4 sec. 20, is from one-half to three-fourths mile wide. The beds of the rivers are about 15 feet below the level of the flood plain. Trees grow along the river courses and along some of the abandoned meanders.

The rocks belong to the lower member of the Fort Union Formation. They consist of interbedded dark-gray and gray shale, brownish-gray carbonaceous shale, light-gray siltstone, small amounts of tan sandstone, and a few thin lenses of coal. The rocks dip westward about 35 feet per mile according to data obtained from logs of wells drilled in the region for oil and gas.

A few thin lenses of coal and shaly coal crop out in the central and eastern parts of the township. These beds are tentatively correlated with the Carter, Snedecker, and Nicholls coal beds of the Coalwood coal field (Bryson, 1952) adjacent to the north.

Carter coal bed.- The Carter coal bed is about 225 feet above the base of the lower member of the Fort Union. It consists of 2 feet of shaly coal at locality 1038 in the NE1/4 sec. 28 and 2 feet 2 inches of coal at locality 1033 in the SE1/4 sec. 21 . 
Local coal bed.-A thin bed of shaly coal about 170 feet above the base of the lower member was measured at 10 localities. The bed may be at or near the stratigraphic position of the Snedecker bed.

Nicholls coal bed.-The Nicholls coal bed at the base of the lower member is 2 feet 5 inches thick; it is overlain by shaly coal 6 feet 10 inches thick at locality 1027 in the NE1/4 sec. 8. The bed is of little value and was not included in table 3.

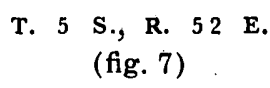

T. 5 S., R. 52 E., is characterized by rolling grass-covered treeless slopes, moderately rolling in much of the area and steeply rolling near the Little Powder River valley. The Little Powder River flows nearly due north across the township in a wide flood plain. Away from the river valley the grass-covered slopes are interrupted in many places by patches of barren banded slopes which expose the interbedded gray and dark-gray shale and lightgray siltstone of the lower member of the Fort Union Formation. A few barren banded buttes on the divides rise above the rolling

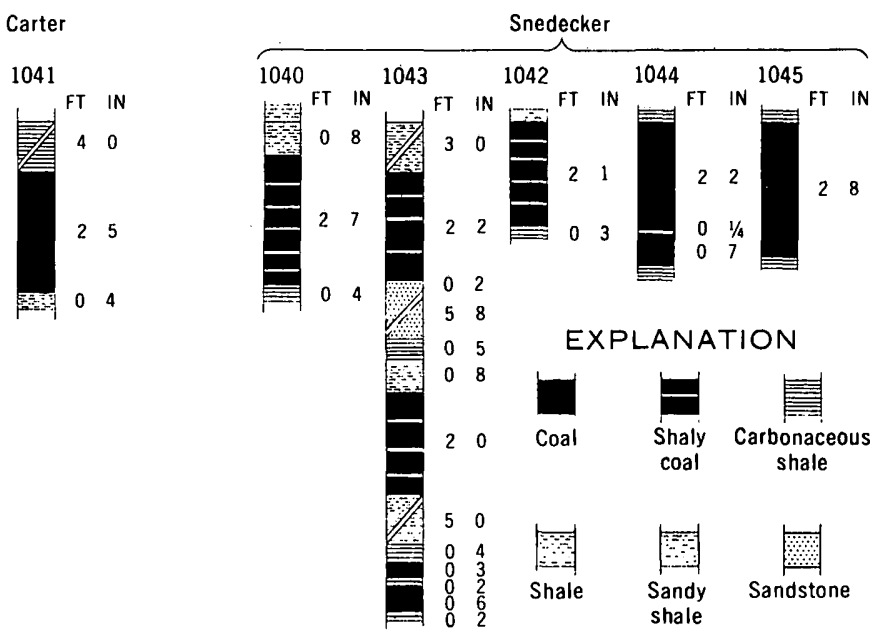

FIGURE 7.-Graphic sections of coal beds in T. 5 S., R. 52 E., Moorhead coal field, Montana. 
grassland. The flood plain of the Little Powder River is one-half to three-fourths mile wide, and the river bed is about 15 feet below the level of the flood plain. Trees grow along the river course and along some of the abandoned meanders.

Except for the alluvium along the Little Powder River, the township is underlain by the lower member of the Fort Union Formation. The rocks dip westward about 35 feet per mile according to data obtained from logs of wells drilled in the region for oil and gas.

In only a few local areas are there lenticular coal beds. A coal bed, 2 feet 5 inches thick, which is about 225 feet above the base of the lower member, was tentatively identified at locality 1041 in the SE1/4, sec. 1 as the Carter coal bed. A coal bed tentatively correlated with the Snedecker bed, which is 170 feet above the base of the lower member, was measured at five localities. It ranges from thin beds of shaly coal to a coal bed 2 feet 9 inches thick.

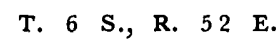

(fig. 8)

T. 6 S., R. 52 E., has a rolling grass-covered treeless surface
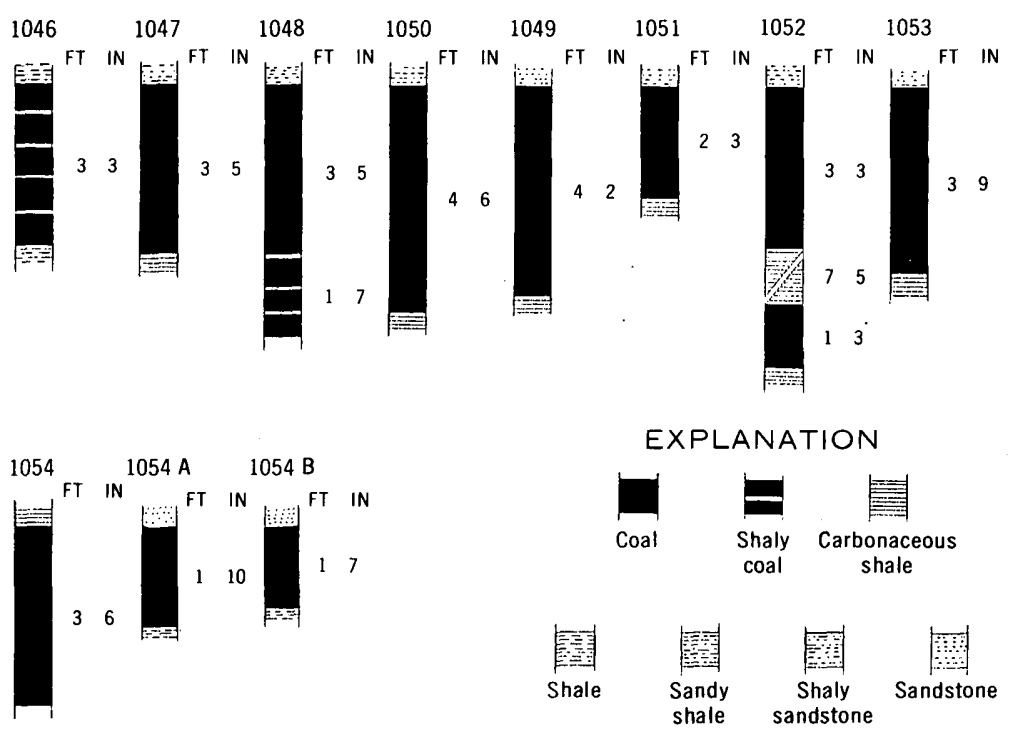

FIGURE 8.-Graphic sections of Snedecker coal bed, T. 6 S., R. 52 E., Moorhead coal field, Montana. 
which is cut by the northward-trending wide valley of the Little Powder River. The western part of the township is gently rolling, and the part near the river is steeply rolling. Patches of barren slopes, particularly near the river valley, expose sequences of interbedded somber-gray shale and thin units of light-gray siltstone. Lenses of dark-brown sandstone cap a few buttes. The flood plain along the Little Powder River is three-fourths to 1 mile wide, and the river bed is about 15 feet below the level of the flood plain. Trees grow along the river course and along some of the abandoned meanders.

Except for an irregular, narrow belt of country in secs. 18, 19,30 , and 31 , where the lowermost part of the Tongue River Member, including the trace of the Olsen or Contact coal bed, occupies the surface, this township is underlain by the lower member of the Fort Union Formation, which is composed of somber brownish-gray siltstone, shale, and sandstone and a few thin lenticular beds of coal. The rocks dip westward about 40 feet per mile according to data obtained from logs of wells drilled in the region for oil and gas.

A coal bed, which may be equivalent to the Snedecker coal bed of the Coalwood coal field (Bryson, 1952), which adjoins this coal field on the north, crops out in the central part of the township. Its thickness ranges from less than 2 feet to 4 feet 6 inches. It is thickest in secs. 17 and 21 and is less than 2 feet thick in sec. 34; it is shaly in the central part of sec. 9 .

$$
\text { T. } 7 \text { S., R. } 52 \text { E. }
$$

(fig. 9)

T. 7 S., R. 52 E., is characterized by a rolling grass-covered treeless surface, gently rolling in most of the township but steeply rolling near the Little Powder River. Barren patches, which occur particularly near the river, interrupt the grass-covered slopes and expose a succession of dark-gray and gray shale and lesser amounts of light-gray siltstone. A few barren banded buttes capped by thin beds of dark-brown sandstone are present on the divides. The Little Powder River flows in a broad valley that trends northward in the east half of the township. Trees grow along the meandering river course and along some of the abandoned meanders.

Except for an irregular narrow strip along part of the west margin, where the lowermost part of the Tongue River Member 

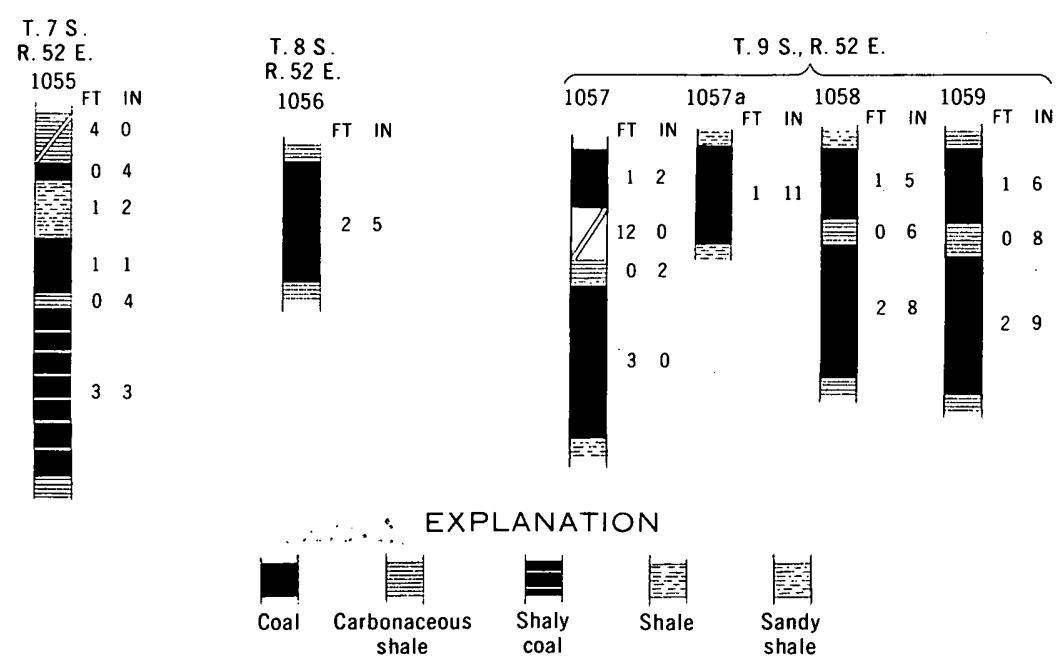

Figure 9.-Graphic sections of local coal beds in Tps. 7, 8, and 9 S., R. 52 E., Moorhead coal field, Montana.

occupies the surface, the township is underlain by the lower member of the Fort Union Formation, which is composed of gray shale interbedded with dark-gray and brownish-gray shale, lightgray siltstone, small amounts of sandstone, and a few thin lenticular beds of coal. The rocks dip westward about 55 feet per mile, according to data obtained from the logs of wells drilled in the region for oil and gas.

The trace of the Olsen or Contact coal bed projects into the westernmost part of the township in secs. 6, 7, 18, and 19. Coal of significant thickness was found only at locality 1055 in the $\mathrm{NE} 1 / 4$ sec. 5 . Here a bed of shaly coal 3 feet 3 inches thick and of little value is separated from a coal bed 1 foot 1 inch thick by a shale 4 inches thick.

$$
\text { T. } 8 \text { S., R. } 52 \text { E. }
$$

(fig. 9)

T. 8 S., R. 52 E., is characterized by a rolling grass-covered surface interrupted by the wide valley of the Little Powder River, which flows northward across the township a short distance east of its middle. The surface is generally devoid of trees except near ranchhouses and along the course of the river and a few of its abandoned meanders. The grass-covered slopes are interrupted, particularly near the river where the slopes are steeper, by barren patches of gray shale interbedded with dark-gray shale 
and small amounts of light-gray siltstone. Some buttes and ridges, particularly those in the southeastern quarter of the township east of the Little Powder River, exhibit banded barren slopes.

Except for the belt of alluvium along the Little Powder River, small areas along Ranch and Wright Creeks, and a few patches of terrace gravel deposits west of the river, the surface is occupied by the lower member of the Fort Union Formation, which consists of gray shale interbedded with dark-gray and brownishgray shale, light-gray siltstone, a little sandstone, and a very few thin lenses of coal. Small areas along Ranch and Wright Creeks are underlain by the Hell Creek Formation. The rocks dip westward about 75 feet per mile according to data obtained from logs of wells drilled in the region for oil and gas.

The outcrop of a thin bed of coal was mapped across sec. 10 and parts of adjacent sections. The coal is 2 feet 5 inches thick at locality 1056 in the $\mathrm{NW}^{1 / 4} \mathrm{NW} 1 / 4$, sec. 10 . A coal bed less than 2 feet thick is present in the SW1/4 sec. 1. A local coal bed, which is 3 feet thick at a locality a few hundred feet south of this township, crops out in the SW1/4 sec. 31 .

\section{T. 9 S., R. 52 E. \\ (fig. 9)}

The Little Powder River has cut a broad valley that trends irregularly northward across the middle of T. 9 S., R. 52 E. The river's flood plain, about three-fourths mile wide, supports patches of cottonwood trees near the stream course and along some abandoned meanders. The surface is fairly deeply dissected in belts one-half to 1 mile wide bordering the river flood plain. Here many patches of bare rock are exposed in steep partly grasscovered slopes. The southwest flanks of ridges between tributaries east of the Little Powder River exhibit barren banded slopes of gray shale interbedded with dark-gray shale and some light-gray to light-yellow-gray siltstone. There appears to be a greater proportion of siltstone here than farther north near Broadus. Away from the river the surface is rolling, grasscovered, and treeless.

Except for the alluvium along the Little Powder River and along Ranch Creek, a few small areas of terrace gravel, and a narrow belt along Ranch Creek, the lower member of the Fort Union Formation is at the surface throughout the township. The Hell Creek Formation is present in a belt of country about half a mile 
wide along Ranch Creek. The rocks dip westward about 90 feet per mile according to data obtained from the logs of wells drilled in the region for oil and gas.

A local lenticular coal bed is 3 feet thick at locality 1057 in the NW1/4 sec. 6. It is only 1 foot 11 inches thick at locality $1057 \mathrm{a}$ in the $\mathrm{S} 1 / 2$ sec. 6. A thin bed of coal is 4 feet 7 inches thick, including a parting 6 inches thick, at locality 1058 in the SW $1 / 4 . S^{1} 1 / 4$ sec. 32 , and it is 4 feet 11 inches thick at locality 1059 in the SE1/4, sec. 32 .

\section{REFERENCES CITED}

American Society for Testing and Materials, 1966, Tentative specifications for classification of coals by rank (D 388-64T), Part 19 of Book of ASTM Standards : p. 73-78.

American Stratigraphic Company, Denver, Colo., well logs, various years.

Baker, A. A., 1929, The northward extension of the Sheridan coal field, Big Horn and Rosebud Counties, Montana: U.S. Geol. Survey Bull. 806-B, p. 15-67.

Bass, N. W., 1932, The Ashland coal field, Rosebud, Powder River, and Custer Counties, Montana: U.S. Geol. Survey Bull. 831-B, p. 19-105.

Brown, R. W., 1952, Tertiary strata in eastern Montana and western North and South Dakota, in Sonnenberg, F. P., ed., Billings Geol. Soc. Guidebook, 3d Ann. Field Conf., Black Hills-Williston Basin, September 1952 : p. 89-92.

Bryson, R. P., 1952, The Coalwood coal field, Powder River County, Montana: U.S. Geol. Survey Bull. 973-B. p. 23-106.

Combo, J. X., Brown, D. M., Pulver, H. F., and Taylor, D. A., 1949, Coal resources of Montana: U.S. Geol. Survey Circ. 53, 28 p.

Oil and Gas Journal, 1970, Modest gains forecast for 1970: Jan. 26, v. 68, no. 4, p. 113-139.

Olive, W. W., 1957, The Spotted Horse coalfield, Sheridan and Campbell Counties, Wyoming: U.S. Geol. Survey Bull. 1050, 83 p.

Parker, J. M., 1958, Stratigraphy of the Shannon member of the Eagle formation and its relationship to other units in the Montana group in the Powder River Basin, Wyoming and Montana, in Wyoming Geol. Assoc. Guidebook, 13th Ann. Field Conf., Powder River Basin, 1958: p. 90-102.

Richards, P. W., and Nieschmidt, C. L., 1961, The Bighorn dolomite and correlative formations in southern Montana and northern Wyoming: U.S. Geol. Survey Oil and Gas Inv. Map OM-202.

Sandberg, C. A., 1962, Geology of the Williston basin, North Dakota, Montana, and South Dakota, with reference to subsurface disposal of radioactive wastes: U.S. Geol. Survey open-file report, $148 \mathrm{p}$.

Strickland, J. W., 1958, Habitat of oil in the Powder River Basin, in Wyoming Geol. Assoc. Guidebook, 13th Ann. Field Conf., Powder River Basin, 1958: p. 132-147. 
Thom, W. T., Jr., and Dobbin, C. E., 1924, Stratigraphy of Cretaceous-Eocene transition beds in eastern Montana and the Dakotas: Geol. Soc. America Bull., v. 35, no. 3, p. 481-505.

Trotter, J. F., 1963, The Minnelusa play of the northern Powder River, Wyoming and adjacent areas, in Wyoming Geol. Assoc. and Billings Geol. Soc. 1st Joint Field Conf., Northern Powder River Basin Guidebook, Wyoming and Montana, 1963: p. 117-122.

Trumbull, J. V. A., 1959, Coal fields of the United States, sheet 1: U.S. Geol. Survey Coal Map.[1960]

U.S. Geological Survey and American Association of Petroleum Geologists, 1961, Tectonic map of the United States, exclusive of Alaska and Hawaii (revised) : 2 sheets, scale $1: 2,500,000$.

Warren, W. C., 1959, Reconnaissance geology of the Birney-Broadus coal field, Rosebud and Powder River Counties, Montana: U.S. Geol. Survey Bull. 1072-J, p. 561-585.[1960]

Wood, H. E., and others, 1941, Nomenclature and correlation of the North American Continent Tertiary: Geol. Soc. American Bull., v. 52, no. 1, p. 1-48. 


\section{INDEX}

[Italic page numbers indicate major references]

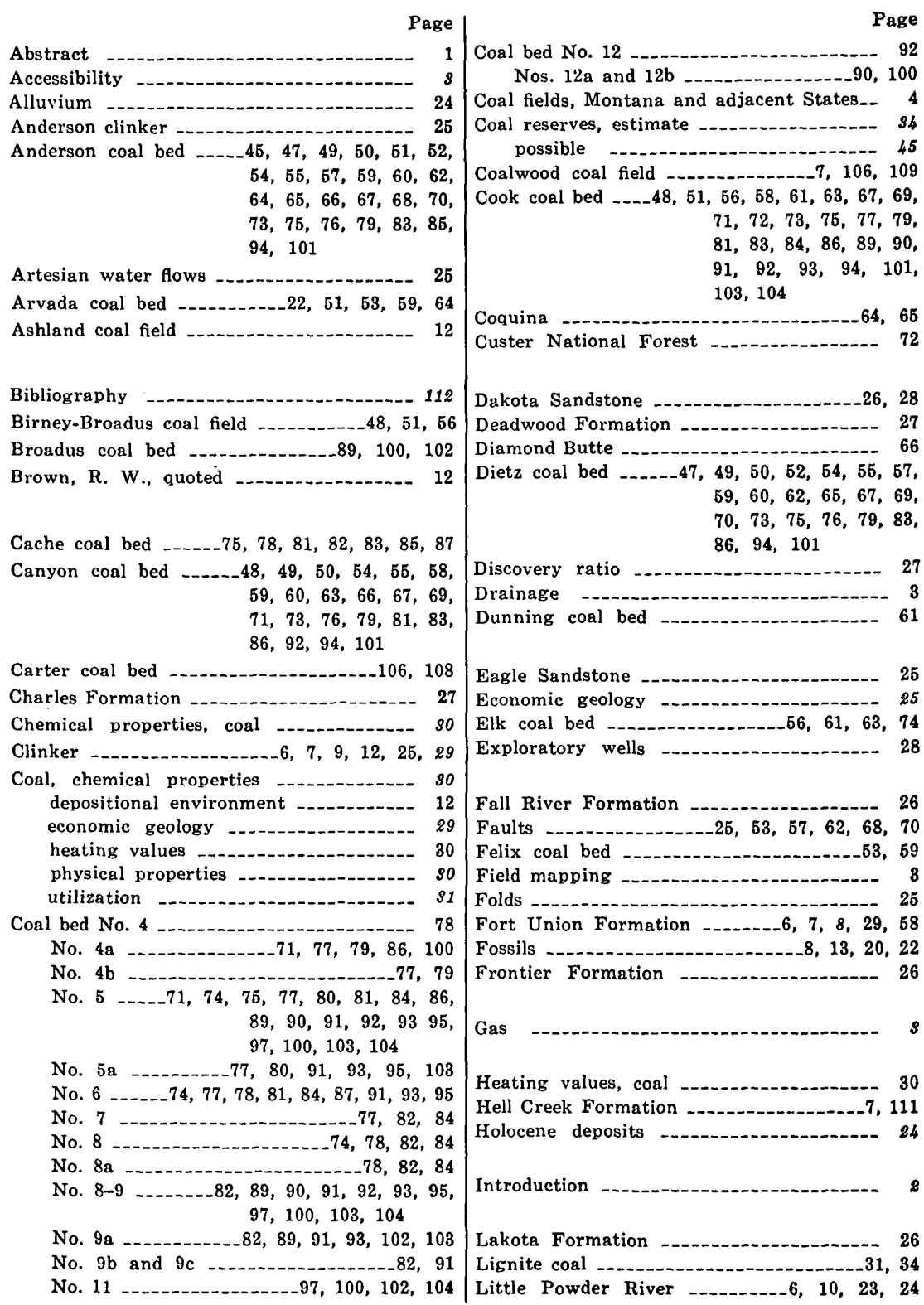


Page Page

Local coal beds

$47,48,50,52,63,54,55$, $57,59,60,61,62,63$, $65,66,70,77,79,81$, $84,86,95,96,97$, $101,102,103,105$, $106,110,111,112$

Location of Moorhead coal field --.------ $s$

Lodgepole Formation -

Lower member of the Fort Union Formation -..-9, 87, 89, 95, 96, 97, 103, $104,106,107,108,109$, 111

Mesaverde Formation 26

Minnelusa Formation $26,27,29$

Mission Canyon Formation -..--.-_-_-_..- 27

Moisture content, coal _-___-_._-_._-_._- 31

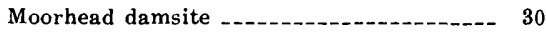

Morrison Formation

26, 29

Newcastle Formation

Nicholls coal bed

Oil

Oil pools

Oil reservoirs

Olsen (Contact) coal bed _..-100, 102, 103 104,110

Opeche Shale 27

Otter coal bed ......48, 51, 56, 58, 61, 63, 67

Parkman Member of the Mesaverde Formation $-26,28$

Pawnee coal bed 48,77

Physical properties, coal

Pleistocene deposits 30

Powder River -

Powder River Basin _................. 24

Quaternary system 23

Railroads

Rocky Point oil pool

Roland coal bed $13,22,51,52,53,57$, $58, \quad 59,62,64,65$

Seismograph surveys
Shannon Sandstone Member of the Steele

Shale --.---

Sheridan coal field _._._.

Silicified tree stumps

$59,65,67$

Smith coal bed _._._._47, 49, 50,52, 54, 57,

$59,62,65,67,68$

Snedecker coal bed _._._._._._._._106, 108, 109

Spotted Horse coal field ...............-22, 71

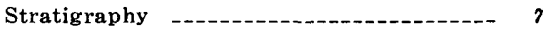

Stratigraphic position, principal coal beds_ 30

Stratigraphic section, lower member, Fort

Union Formation -..------ 10

pre-Permian rocks _...........-. 28

Tongue River Member, Fort Union Formation -................- 13

Wasatch Formation -...-..-_-_ 20

Streams _..................... 6

Strip mine, Gillette, Wyo -_._-_._. 34

Structure -................ 24

Subbituminous coal _-_._._._-_._-_-_31, 34

Subsurface structure-contour maps -...-. 27

Sundance Formation -................ 26

Sussex Sandstone Member of the Steel Shale -

Teapot Sandstone Member of the Mesaverde Formation -..--.---.- 26

Terrace gravel -............. 23

Tertiary system

Thickness maps ............. 27

Tongue River Member of the Fort Union Formation $-. .6,8,12,29,45,47$, $49,51,53,55,56,57$, $58,60,62,63,64,66$, $68,70,72,75,76,78$, $83,85,89,90,92,94$, $97,100,101,102,103$, 104,109

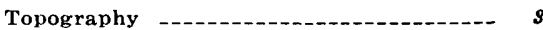

Turret Buttes -.... 90

Two Trees mine _.......... 30

Upper Cretaceous Series -..--

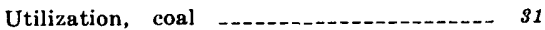

Wall coal bed

Wasatch Formation $-.20,29,49,51,53,58,64$ 27 Winnipeg Formation 27 